\title{
POPULAR CONSTITUTIONALISM AND THE RULE OF RECOGNITION: WHOSE PRACTICES GROUND U.S. LAW?
}

Matthew D. Adler

INTRODUCTION.

I. Hart Versus Dworkin ReduX: The Problem of THE ReCOGNITIONAL

COMMUNITY

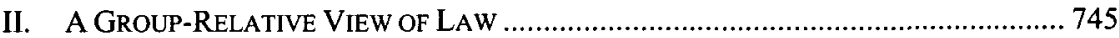

A. Recognitional Communities as Shared Cooperative Activities .................. 750

B. "Constitutive" Rules, Lewis-Conventions, and Social Norms................... 765

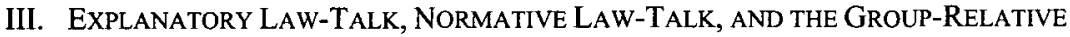

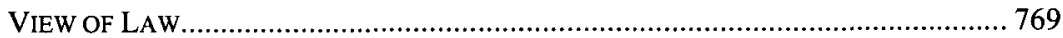

A. Law as a Predictive/Explanatory Concept .......................................... 771

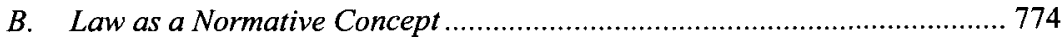

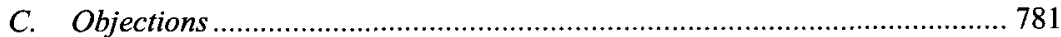

IV. GRoup-RELATIVITY AND CONSTITUTIONAL LAW ......................................... 790

A. The Structure of Constitutional Discourse ............................................ 790

B. Popular Constitutionalism, Shallow and Deep ................................... 797

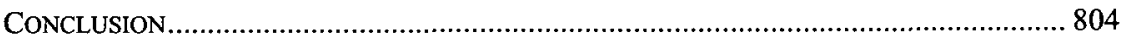

\section{INTRODUCTION}

Is "popular constitutionalism" possible? Much recent constitutional scholarship, including books and articles by such prominent academic figures as Neal Katyal, Larry Kramer, Robert Post, Reva Siegel, Mark

Professor of Law, University of Pennsylvania Law School. Many people have helped me with this Article. Thanks for their comments to Larry Alexander, Brian Bix, Rebecca Brown, Bill Ewald, Claire Finkelstein, Jim Fleming, Barry Friedman, Frank Goodman, Michael Green, Ken Himma, Rick Hills, Larry Kramer, Matthew Kramer, Dennis Patterson, Stephen Perry, Eric Posner, Ed Rock, Tony Sebok, Paul Shupack, Larry Solum, Adrian Vermeule, Ben Zipursky, and an anonymous referee for $L e$ gal Theory. Special thanks to Richard Fallon, Kim Roosevelt, and Scott Shapiro, who served as commentators on the Article at the NYU Constitutional Theory Conference, the University of Pennsylvania Law School faculty retreat and the Cardozo School of Law faculty workshop, respectively. Thanks also to participants in those sessions, faculty workshops at Brooklyn, Fordham and Rutgers-Camden law schools, and a panel at the XXII World Congress of Philosophy of Law and Social Philosophy, for their reactions. Finally, thanks to Abby Wright for excellent research assistance. All errors are my own. 
Tushnet, Jeremy Waldron, and Keith Whittington, argues for some variant of "popular constitutionalism"-for some inclusion of popular views about the Constitution in constitutional decisionmaking.' These recent contributions build on existing work, particularly by Akhil Amar, Robert Burt, Neal Devins, Frank Easterbrook, Barry Friedman, Sanford Levinson, Michael Paulsen, and Robin West, and, outside the legal academy, by political scientists such as Walter Murphy. ${ }^{2}$ Bruce Ackerman's heroic attempt to rethink American constitutional history and theory, in his magnum opus We the People, ${ }^{3}$ also represents a kind of "popular constitutionalism." But is this a coherent position?

The question I want to press here is not whether institutions affording citizens a role in constitutional decisionmaking are morally advisablewhether, for example, the benefit to democratic values in departing from a regime of judicial supremacy, where the Supreme Court is empowered to definitely settle constitutional questions, outweighs the costs, such as increased uncertainty. ${ }^{4}$ My question is a prior and (dare I say) deeper one. Theorists of law, starting with H.L.A. Hart and his seminal work The Concept of Law, have told us that law is a kind of norm ultimately grounded in official practice. ${ }^{5}$ The legal rights, duties, liberties, powers, liabilities, im-

I See larry D. Kramer, The People Themselves: Popular Constitutionalism and Judicial Review (2004) [hereinafter KRamer, THE PEOPLE Themselves]; MARK TUSHNET, TAKING THE CONSTITUTION AWAY FROM THE COURTS (1999); JEREMY WALDRON, LAW AND DiSAGREEMENT (1999); Neal Kumar Katyal, Legislative Constitutional Interpretation, 50 DUKE L.J. 1335 (2001); Larry D. Kramer, Foreword: We the Court, 115 HARV. L. REV. 5 (2001) [hereinafter Kramer, We the Court]; Robert C. Post, Foreword: Fashioning the Legal Constitution: Culture, Courts and Law, 117 HARV. L. REV. 4 (2003); Robert C. Post \& Reva B. Siegel, Legislative Constitutionalism and Section Five Power: Policentric Interpretation of the Family and Medical Leave Act, 112 YALE L.J. 1943 (2003); Keith E. Whittington, Extrajudicial Constitutional Interpretation: Three Objections and Responses, 80 N.C. L. REV. 773 (2002).

${ }^{2}$ See Robert Burt, The Constitution in Conflict (1992); Neal Devins, Shaping Constitutional Values: Elected Government, THE Supreme COURT, AND the Abortion Debate (1996); SANFord LeVInson, Constitutional Faith (1988); Robin West, Progressive CONSTITUTIONALISM: RECONSTRUCTING THE FOURTEENTH AMENDMENT (1994); Akhil Reed Amar, Popular Sovereignty and Constitutional Amendment, in RESPONDING TO IMPERFECTION: THE THEORY AND PRACTICE OF CONSTITUTIONAL AMENDMENT 89 (Sanford Levinson ed., 1995); Frank H. Easterbrook, Presidential Review, 40 CASE W. RES. L. REV. 905 (1990); Barry Friedman, Dialogue and Judicial Review, 91 MICH. L. REV. 577 (1993); Walter F. Murphy, Who Shall Interpret?: The Quest for the Ultimate Constitutional Interpreter, 48 REV. POL. 401 (1986); Michael Stokes Paulsen, The Most Dangerous Branch: Executive Power to Say What the Law Is, 83 GEO. L.J. 217 (1994). See generally Matthew D. Adler, Judicial Restraint in the Administrative State: Beyond the Countermajoritarian Difficulty, 145 U. PA. L. REV. 759, 876-77 nn.330-31 (1997) (citing literature on "departmentalism").

3 1 BRUCE ACKERMan, We THE PEOPLE: Foundations (1991) [hereinafter ACKerman, Foundations]; 2 Bruce ACKerman, We the PEOPle: Transformations (1998) [hereinafter ACKERMAN, TRANSFORMATIONS].

${ }^{4}$ Cf. Adler, supra note 2, at 785-806 (discussing moral, democratic argument for judicial restraint).

5 See H.L.A. HART, THE CONCEPT OF LAW (2d ed. 1994); infra notes 47-73 and accompanying text (discussing Hart's view, and that of some contemporary positivists, that the rule of recognition is constituted by official practice). 
munities, and disabilities that exist in each legal system are just those putative rights, duties, etc., that are validated by what Hart called the rule of recognition: the rule for identifying law that is accepted as the ultimate rule by officials in the legal system, particularly judges.

On the Hartian account, citizen understandings and practices cannot have a bedrock role in constituting the legal system. This account creates a painful dilemma for "popular constitutionalists." The claim advanced by Katyal, Kramer, Post, Siegel, Tushnet, Waldron, Whittington et al. might be (1) that the legal status of citizen involvement in constitutional decisionmaking hinges on, and is delimited by, officials' views about what the fundamental legal principles of our system are. Alternatively, their claim might be (2) that citizen views have a larger role in shaping the legal system, a coequal or dominant role. In the first case, the "popular" quality of constitutionalism turns out to be shallow. In the second case, the popular constitutionalists' claim is, on the Hartian view of law, conceptually and necessarily false, like a claim that "some squares are round" or "some bachelors are married."

Consider, for example, the variant of "popular constitutionalism" which asserts that judges and officials should be responsive to the constitutional views expressed by citizens in elections, demonstrations, and other political activities. Larry Kramer argues that the eighteenth century Whig constitutionalism animating the American Revolution and accepted by the Framers envisioned popular voting, petitioning, and "mobbing" as primary mechanisms by which constitutional provisions would be enforced. As Kramer describes the debates at the Constitutional Convention:

Anti-Federalists were convinced that the Constitution's restrictions would prove porous and ephemeral .... And because virtually every Anti-Federalist offered this threat as one of the best reasons to reject the Constitution, practically every Federalist was forced to refute the claim by showing how the Constitution would be enforced.

But how did Federalists think this would happen, if not by judicial review? By now, the answer should be obvious: politics. The kind of politics that we have seen defined popular constitutionalism throughout the seventeenth and eighteenth centuries. When Anti-Federalists insisted that Congress would disregard the Constitution's limits, Federalists invariably responded that any effort to do so would run smack into opposition from the people. Let Congress try to misuse its powers . . . and federal lawmakers would find themselves facing formidable popular resistance--via elections, juries, popular outcries, or, in the unlikely event that all of these failed, by more violent forms of opposition. ${ }^{6}$

Bruce Ackerman's idea of informal constitutional amendments is a tidier version of the mechanisms Kramer describes: ideally, individual citizens

${ }^{6}$ Kramer, We the Court, supra note 1, at 72. 
don't threaten or "mob" the legislators, but they do go to the polls in pivotal national elections, taking up a "signal" from the President or Congress, and when the citizenry in its voting behavior decisively endorses a particular constitutional understanding, that view becomes real constitutional law, binding on the Supreme Court and other judges and officials. ${ }^{7}$

The dilemma that Hart's view poses for the Kramer/Ackerman conception of popular constitutionalism is this. Imagine that officials accept a "rule of recognition" which precludes deference, on constitutional matters, to citizen views expressed in voting, petitioning, and "mobbing." Judges and legislators say things like: "Constitutional law is the framework for majoritarian democracy. Elections and political activity play a central role within that framework, but the framework itself is set forth by the text of the Constitution, and political processes such as voting or lobbying have no legitimate function in guiding the interpretation of that text." Whether officials do say and think this is, of course, an empirical question. They might not. But if they do, it follows that - on the Hartian view of law-there is simply no purchase for the argument that officials are legally obligated to defer to citizen constitutional views. Official practice settles what officials are legally obligated to do. ${ }^{8}$

The "popular constitutionalist," faced with official resistance to the claim that officials should defer to citizen constitutional views, would surely be tempted to appeal to citizen opinion on the very issue of constitutional authority. It would seem plausible to say something like: "Although officials may believe that they are authoritative on constitutional matters, ordinary citizens have gone to the polls and to the streets with a different belief, namely that they too have a role in constitutional interpretation. And legal arguments about constitutional authority structures should take account of these citizen views." "But, if Hart is correct, citizen beliefs about the role of voting and other forms of popular political expression in constitutional decisionmaking are necessarily legally irrelevant, absent some validation of those beliefs by officials. Citizens have no legal role in constitutional decisionmaking unless officials come to believe that they do or at least come to accept other rules from which a citizen role is derivable.

7 See 1 ACKERMAN, Foundations, supra note 3, at 266-94.

8 To be sure, if officials accept the proposition that officials need not defer to citizen constitutional views, not as part of the ultimate rule of recognition, but as a subsidiary proposition which they believe to be derivable from the propositions they accept as ultimate or axiomatic, then-on the Hartian view of legal validity - the nondeference principle could be challenged as legally incorrect. However, it's certainly possible for officials to accept a nondeference principle as ultimate. Further, it may well be that the Hartian view of legal validity as derivability from a rule that officials take to be ultimate needs to be changed-so that derivative propositions generally accepted by officials (or whatever the recognitional group) are law in virtue of this acceptance. On these issues, see infra notes 163-168 and accompanying text.

9 See infra note 31 and accompanying text. 
A legal argument that appeals to citizen practice in the teeth of the official rule of recognition must necessarily fail.

Indeed, some positivists appear to take the position that a legal argument which appeals to nonjudicial practice in the teeth of the judicial rule of recognition must necessarily fail. Hart, in his now-famous Postscript to The Concept of Law, published some thirty years after the original volume, writes: "[T] he rule of recognition . . . is in effect a form of judicial customary rule existing only if it is accepted and practiced in the law-identifying and law-applying operations of the courts." 10 The original volume seems to say that the rule of recognition is a social rule practiced by officials generally (legislators and executive officials as well as judges), ${ }^{11}$ but the sentence just quoted suggests otherwise. It suggests that every legal system (including ours) is ultimately grounded in judicial practice-that true legal rights, duties, etc., are those putative rights, etc., recognized as legally valid by the criteria of validity that judges practice and accept. Joseph Raz, a student of Hart and now a very prominent jurisprudent, has argued explicitly that judicial practice within each legal system, not citizen or official practice, provides its foundations. Chris Kutz has recently seconded this view. ${ }^{12}$

Consider what the Raz/Kutz account implies for challenges to judicial supremacy. All of the concrete legal proposals advanced by "popular constitutionalists" seek to qualify judicial supremacy. Some suggest, like Ackerman, that judges should defer to certain constitutional views directly expressed by citizens in voting and other citizen-involving political processes. ${ }^{13}$ Other proposals are more indirect, seeing legislatures, particularly Congress, as conduits or mouthpieces (pick your metaphor) for popular constitutional opinion. Much recent scholarship argues for judicial deference to Congress on certain constitutional matters - through "rational basis" tests, ${ }^{14}$ Thayerian "minimalism,"15 the "political question" doctrine, ${ }^{16}$ or

${ }^{10}$ HART, supra note 5, at 256; see id. at vii-ix (discussing circumstances leading to posthumous publication of the Postscript).

11 See id. at 111-17; infra notes 47-62 and accompanying text.

12 See infra notes 74-78 and accompanying text.

13 See 1 ACKERMAN, FoUndaTIONS, supra note 3; 2 ACKERMAN, TRANSFORMATIONS, supra note 3; Amar, supra note 2. Larry Kramer argues that extralegislative expressions of popular constitutional views once played a central role in our constitutional regime. See supra note 6 and accompanying text. However, Kramer's recommendations for current practice focus on judicial deference to Congress, in some domains, and reciprocally on the rejection of Cooper v. Aaron. See KRAMER, THE PEOPLE THEMSELVES, supra note 1, at 207-53; Kramer, We the Court, supra note 1, at 110-69.

${ }^{14}$ See Paul Brest, The Conscientious Legislator's Guide to Constitutional Interpretation, 27 STAN. L. REV. 585, 594-99 (1975) (discussing rational basis review as a mechanism for judicial deference); Lawrence Gene Sager, Fair Measure: The Legal Status of Underenforced Constitutional Norms, 91 HARV. L. REV. 1212, 1215-20 (1978) (same).

${ }^{15}$ See James B. Thayer, The Origin and Scope of the American Doctrine of Constitutional Law, 7 HARV. L. REV. 129 (1893) (arguing for a clear-error approach to judicial review of legislation); Adler, supra note 2, at 844-53 (discussing Thayer's position, now often called "minimalism"). 
other such devices that reduce the intensity of judicial scrutiny of legislation. ${ }^{17}$ The proposals here might be generic, or focused on particular parts of the Constitution-for example, Kramer's proposal that the Supreme Court be especially lenient in enforcing the constitutional provisions that delimit the scope of national legislative power, ${ }^{18}$ or the Post/Siegel claim that Congress should be permitted to effectuate its own, more expansive understandings of constitutional rights in legislating pursuant to Section 5 of the Fourteenth Amendment. ${ }^{19}$ At the extreme, it might be argued that courts should simply cease enforcing the Bill of Rights (Waldron), or indeed that the entire practice of judicial review should stop (Tushnet).

Judicial supremacy might be qualified, too, by limiting the legal force of Supreme Court decisions. In Cooper v. Aaron ${ }^{20}$ the Court stated that its constitutional rulings - the propositions of constitutional law announced in its opinions-are legally binding on all nonjudicial officials, not merely the parties to the case in which the rulings are announced. Many scholars reject Cooper, ${ }^{21}$ typically drawing a distinction between the binding force of judicial judgments versus opinions (even Supreme Court opinions). ${ }^{22}$ Michael Paulsen has gone so far as to suggest that a court's constitutional rulings do not even legally bind parties. ${ }^{23}$

Consider any one of these proposed qualifications to judicial supremacy: judicial responsiveness to elections; judicial deference, or indeed the wholesale abandonment of judicial review, in reviewing statutes, in some or all constitutional domains; freedom on the part of legislators, Presidents,

${ }^{16}$ See generally Rachel E. Barkow, More Supreme than Court?: The Fall of the Political Question Doctrine and the Rise of Judicial Supremacy, 102 COLUM. L. REV. 237 (2002).

17 For examples of scholarship in a "popular constitutionalist" vein that argues for judicial deference to Congress, see TUSHNET, supra note 1, at 154-76; WALDRON, supra note 1, at 211-14; WEST, supra note 2, at 295-96; Kramer, We the Court, supra note 1, at 122-28; Post \& Siegel, supra note 1, at 194552. Of course, many constitutional scholars who are not particularly populist in their sensibilities agree that there are some domains in which the Court should defer to Congress. For an influential example, see Sager, supra note 14. The proposition, announced in Carolene Products's famous footnote, that judicial review should only be selectively nondeferential, is a cornerstone of post-New Deal constitutional theory. See United States v. Carolene Products Co., 304 U.S. 144, 152 n.4 (1938).

${ }_{18}$ See, e.g., Kramer, We the Court, supra note 1, at 151-53.

19 See Post \& Siegel, supra note 1, at 1945-52.

20358 U.S. 1 (1958).

${ }^{21}$ See, e.g., BURT, supra note 2, at 353-75; DEVINS, supra note 2, at 157-62; KRAMER, THE PEOPLE THEMSELVES, supra note 1, at 233-53; LEVINSON, supra note 2, at 46-50; TUSHNET, supra note 1, at 6-32; Easterbrook, supra note 2, at 924-27; Gary Lawson \& Christopher D. Moore, The Executive Power of Constitutional Interpretation, 81 IOWA L. REV. 1267, 1268-71 (1996); Murphy, supra note 2, at 417; Whittington, supra note 1, at 786-808. For further examples, see Adler, supra note 2, at 876 n.330 (citing relevant sources); Larry Alexander \& Frederick Schauer, Of Extrajudicial Constitutional Interpretation, 110 HARV. L. REV. 1359 (1997) (same).

22 See Lawson \& Moore, supra note 21, at 1313-14 ("With the notable exception of Professor Michael Stokes Paulsen, every modem departmentalist scholar has maintained that the President has an obligation to enforce specific judgments rendered by the federal courts ....").

23 See Paulsen, supra note 2, at 276-84. 
and perhaps other officials to disagree with the Court's constitutional rulings. If Raz and Kutz are correct that the U.S. rule of recognition, the ultimate criterion of legal validity in our system, is constituted by judicial practice, then all of these proposed limitations on judicial supremacy must ultimately be legally justified by appeal to judicial practice. Judges might be legally required to defer to Congress on certain issues, but only if judges agree that deference is required or at least accept other axioms from which deference is derivable. The rule of Cooper $v$. Aaron might be legally incorrect, but only if judges themselves explicitly or by implication reject the Cooper rule. On the Raz/Kutz account, the constitutional role of nonjudicial actors is necessarily defined by judges.

The Raz/Kutz account does allow that judicial supremacy, understood as a set of legal doctrines that give courts the primary role in enforcing constitutional norms, might be rejected or qualified. To use vocabulary I will elaborate below, the account allows for departures from the "shallow" variant of judicial supremacy. ${ }^{24}$ Courts can use "rational basis" tests, legislators can be empowered to depart from certain judicial rulings, and so on. But the account insists on a deeper kind of judicial supremacy. At bottom, it is judicial views and practices that determine what techniques should be employed to interpret the text of the Constitution and who is authoritative in settling controversies about the application of these techniques. Indeed, it is judicial views and practices that determine whether the text of the Constitution is the sole source of constitutional law, ${ }^{25}$ what that text currently is (for example, whether it includes the Reconstruction Amendments despite ratification irregularities), ${ }^{26}$ and how the text can be changed (for example, whether the text really governs its own amendment, as Article V purports to do). ${ }^{27}$

The jurisprudential problem for "popular constitutionalism" that I have been exploring might be called the problem of the recognitional community. Hart's doctrine of the "rule of recognition" embodies a crucial insight about law, the force of which all subsequent serious jurisprudents, even antipositivists such as Ronald Dworkin, have acknowledged. Law is, at least in part, a social fact. What is true, legally speaking, in a given legal system, is determined (at least in part) by the practices of some social group. Dworkin and the positivists disagree about how social practices determine legal content. Dworkin insists that the function from social practice to law necessarily involves moral considerations; positivists deny that. But there has been

24 See infra Part IV.B.

25 See Thomas C. Grey, Do We Have an Unwritten Constitution?, 27 STAN. L. REV. 703, 706-10 (1975) (arguing that there are unwritten sources of constitutional law).

${ }^{26}$ See John Harrison, The Lawfulness of the Reconstruction Amendments, 68 U. CHI. L. REV. 375 (2001) (discussing these irregularities).

${ }^{27}$ See Amar, supra note 2 (arguing that Article V provides a nonexclusive procedure for constitutional amendment). 
broad agreement among Anglo-American jurisprudents, starting with the Concept of Law, continuing to the present, and including Dworkin, that the practices of some canonical group play a fundamental role in generating law within a given legal system. ${ }^{28}$

This group, which I will call the "recognitional community," is some collection of persons. But which persons? Assume, for the moment, that the persons from whose practices law derives must be living. Is the recognitional community for the U.S. legal system: (1) all living persons; (2) all living persons physically located within what is generally acknowledged to be the territory of the U.S.; (3) all living persons generally acknowledged to be U.S. citizens; (4) all living persons generally acknowledged to be officials in the U.S. legal system; or (5) all living persons generally acknowledged to be judges in the U.S. legal system? Hart in The Concept of Law answers, all living U.S. officials; Raz and Kutz answer, all living U.S. judges. Deep popular constitutionalism answers, all living U.S. citizens. ${ }^{29}$

"Deep" popular constitutionalism appeals to citizen constitutional culture as the ultimate test of constitutional and, more generally, legal truth. Are Katyal, Kramer, Post, Siegel, Tushnet, Waldron, Whittington and other legal scholars with populist sensibilities deep popular constitutionalists? With the exception of Waldron, ${ }^{30}$ none has addressed or even recognized the question. But many say things that suggest a fairly profound commitment to the role of citizen opinion in determining constitutional matters. ${ }^{31}$ Surely at least some of these scholars would rebel at the suggestion that the federal judiciary is the ultimate authority with respect to the legal correctness of Cooper v. Aaron-that, once Cooper is announced and lower federal judges accept the announcement as valid constitutional law, its nonjudicial opponents have no legal leg to stand on. And surely deep popular constitutionalism is the most straightforward rendering of popular and scholarly talk about the constitutional status of "We the People."

It might be objected that a theorist can criticize judicial or official practices that fly in the face of citizen constitutional understandings as morally

${ }^{28}$ See infra Part 1.

29 See infra Part IV.B (distinguishing between shallow and deep popular constitutionalism).

30 See Jeremy Waldron, All We Like Sheep, 12 CAN. J.L. \& JURISPRUDENCE 169 (1999) [hereinafter Waldron, All We Like Sheep]; Jeremy Waldron, Can There Be a Democratic Jurisprudence? 19-25 (Mar. 2004) (unpublished paper, on file with author) [hereinafter Waldron, Can There Be a Democratic Jurisprudence?].

${ }^{31}$ See, e.g., KRAMER, THE PEOPLE ThemSELVES, supra note 1, at 248 ("The Supreme Court is not the highest authority in the land on constitutional law. We are."); TUSHNET, supra note 1, at 182 ("Populist constitutional law ... treats constitutional law not as something in the hands of lawyers and judges but in the hands of the people themselves."); Post \& Siegel, supra note 1, at 2027 ("The Constitution is not an exclusively legal document. It is not addressed only to courts. . . It is [also] the compendium of values and commitments that hold us [citizens] together despite our diversity and differences."); Waldron, Can There Be a Democratic Jurisprudence?, supra note 30, at 19 (questioning "the assumption implicit in the modern approach to rules of recognition-the assumption that the recognition of norms as law is best understood as a practice among officials"). 
incorrect or misguided without adopting "deep popular constitutionalism" as I have defined it. Deep popular constitutionalism, on that definition, points to citizen practices as the foundation for law. A theorist might concede the Hartian premise that judicial or official practices determine what the law is, yet argue on moral grounds for changing those practices and therewith the law, and point to citizen practices as part of this moral argument. This is true, although I would hazard to guess-given the citizencentric rhetoric of the popular constitutionalism literature-that at least some scholars who style themselves "popular constitutionalists" would refuse to concede the Hartian premise. They would insist that citizen practices trump or at least have coequal status with official or judicial practices in determining what the U.S. Constitution requires as a matter of law, not merely in determining what constitutional law ought to be as a matter of morality or political theory. ${ }^{32}$

It is impossible to know for sure whether Katyal, Kramer et al. are deep or merely shallow popular constitutionalists, based on the published scholarship, since the jurisprudential literature about the nature of the rule of recognition is not a literature that the scholarship on popular constitutionalism generally engages. In any event, it is worth examining how far down popular constitutionalism can go. More generally, it is worth examining whether our recognitional community includes all persons, all U.S. subjects, all U.S. citizens, all U.S. officials, or just all U.S. judges-if indeed we do have a single recognitional community. This Article will grapple with the jurisprudential problem of the recognitional community, and will propose a possible solution with large implications for constitutional theory.

Part I of the Article discusses Hart's doctrine of the "rule of recognition" and its development in the jurisprudential literature. It advances the surprising suggestion that Dworkin, often seen as the least democratic of jurisprudents, is actually a deep popular constitutionalist. While Hart and some successor positivists such as Jules Coleman and Scott Shapiro identify officials as the recognitional community, and other positivists such as Raz and Kutz identify judges as the recognitional community, Dworkin's account seems to identify citizens generally as the foundational group whose practices ground each legal system.

Parts II and III propose and defend an answer to the jurisprudents' debate about the identity of the recognitional community. The answer is deflationary and, I am sure, counterintuitive. No single community defines the law of a given legal system. In particular, there is no canonical group whose practices are the foundation for U.S. law. Propositions about U.S. constitutional law and, derivatively, U.S. law more generally are true or false relative to the practices of a stipulated group.

32 See E-mail from Larry Kramer, Richard E. Lang Professor of Law and Dean, Stanford Law School, to author (Nov. 24, 2004, 9:03 AM EST) (on file with author) (suggesting that Professor Kramer is both a shallow and a deep popular constitutionalist). 
Law is a set of socially grounded norms. Simple social norms are clearly relative to groups. It is absurd to ask what single group defines dress norms, say, even if we are talking just about norms for dress by persons located in a particular, compact, well-understood geographic area (say, the island of Manhattan). We can ask what norms among Manhattan teenagers are for dress by Manhattanites, what norms among Manhattan fashionistas are, what norms among investment bankers are, and so on. What dressing behaviors (by teenagers and others) do teenagers approve? What dressing behaviors (by investment bankers and others) do investment bankers approve? To ask for the single, canonical, recognitional community whose conventions, constitutive rules, joint intentions, or "practices" in some other sense determine the unitary dress norms for Manhattan is a category mistake. The same is true, I will suggest, for the norms of U.S. constitutional law.

My defense of the group-relative view has two parts. First, I argue in Part II that the kind of social practice which gives rise to law can be simultaneously instantiated by multiple groups located within the same territory. I develop this point with reference to U.S. constitutional history, showing how multiple groups, both officials and citizens, have developed and acted on competing conceptions of U.S. constitutional law. Second, I argue in Part III that these competing conceptions are best understood as genuinely distinct bodies of law. "Law" is sometimes a predictive/explanatory concept, sometimes a normative concept. Part III argues that the group-relative view of law is the best specification both of the concept of "law" insofar as it figures in predictive/explanatory discourse, and of that concept insofar as it figures in normative discourse.

Part IV sketches the implications of the group-relativity thesis for constitutional law and theory. Among other things, the thesis helps clarify the debate about popular constitutionalism. I develop the distinction, already alluded to, between the shallow forms of popular constitutionalism and opposing positions, such as judicial supremacy, and the deep forms of popular constitutionalism and opposing positions. Shallow popular constitutionalists and shallow judicial supremacists advocate particular legal doctrines, in particular doctrines regarding the deference that courts engaged in constitutional adjudication should give to nonjudicial actors, or doctrines regarding the binding effect of judicial opinions and judgments. Deep popular constitutionalists and deep judicial supremacists posit different recognitional groups as the foundation for U.S. law.

Legal debates between shallow popular constitutionalists and shallow judicial supremacists are genuine debates. Questions about the allocation of constitutional decisionmaking between judges and nonjudicial actors typically have a legally correct answer. But legal debates between deep popular constitutionalists and deep judicial supremacists are not genuine debates. On the group-relative view of law, any legal argument begins by (explicitly or implicitly) positing some recognitional group. Which group that should 
be is not, itself, settled by the law. Deep popular constitutionalists posit one group (the citizenry), deep judicial supremacists another (judges), and these initial choices cannot be evaluated as legally correct or incorrect in any absolute sense. Deep popular constitutionalists might, I suppose, argue that, relative to citizen practices, it is legally correct to posit citizens as the recognitional group; but deep judicial supremacists might respond that, relative to judicial practices, it is legally correct to posit judges as the recognitional group. Deep popular constitutionalists and deep judicial supremacists offer different conceptions of U.S. law, diverging in the underlying recognitional group but equally valid qua law. U.S. law cannot itself adjudicate any dispute between them.

By contrast, there are morally correct answers to questions about group identification. Is it morally better for judges to identify themselves as judges, as officials, or rather as citizens-to determine their legal powers and duties relative to the first collectivity, or the second, or the third? What about legislators or voters? On these moral issues, deep popular constitutionalists (understood now as claiming that it is morally best for everyone to identify with the same recognitional community, the community of all citizens) versus deep official supremacists versus deep judicial supremacists do have a genuine disagreement. But the deep populists and official and judicial supremacists may very well all be wrong, since it might instead be morally best for some of us to identify with one recognitional community, and others of us to identify with a different one. A heterogeneity of posited recognitional communities, mirroring at a bedrock level the more familiar constitutional heterogeneities - federalism and the separation of powersmight be the morally optimal social structure, at least for us.

\section{HART Versus DWORKIN ReduX: THE PROBLEM OF THE RECOGNITIONAL COMMUNITY}

This Part discusses the jurisprudential literature on the "rule of recognition," surveying the answers provided by Hart, other positivists, and the antipositivist Ronald Dworkin to a question of much import for jurisprudence generally and U.S. constitutional theory in particular, but one that has received too little attention: Whose practices provide the foundation for a given legal system? It turns out that Dworkin and the positivists disagree about the answer to this deep question, as they do (more famously) about other jurisprudential problems.

Law, unlike morality, is essentially social. A moral norm can apply to a subject even though neither the subject, nor anyone else, believes the moral norm to exist or believes in the existence of a moral rule from which the norm is derivable. ${ }^{33}$ The existence of legal norms is not so fully detach-

33 This claim presupposes moral cognitivism, namely that there are moral facts and that moral statements can be true or false, plus nonrelativism, namely that morality and social morality can diverge. Social morality is, roughly, what is commonly believed to be morally required by the members of one or 
able from actual human activity. The existence conditions for legal norms involve actual social practice-where the actual social practice of some group is a fact or other entity that supervenes on the actual beliefs, desires, physical attributes, actions, etc. of persons in that group. Hans Kelsen denied that law is essentially social, ${ }^{34}$ but all prominent Anglo-American jurisprudents since Hart have accepted that it is. As Ken Himma explains:

The most fundamental of positivism's core commitments is the Social Fact Thesis, which asserts that law is, in essence, a social creation or artefact. What distinguishes legal norms from non-legal norms, according to this thesis, is that the former instantiate a property that makes reference to some social fact. The occurrence of the relevant social fact ... is what ultimately explains the existence of a legal system and constitutes it as an artefact. ${ }^{35}$

The antipositivist Dworkin denies that law is only a social fact, but he accepts that the existence conditions for legal norms make partial reference to social fact. ${ }^{36}$ In that sense, Dworkin, too, sees law as grounded in social practice.

Hart's The Concept of Law offers a particular conception of the social fact or practice in which law is grounded. Law, for Hart, derives from a social rule. A social rule, for Hart, is more than a shared habit. Rather, a social rule is practiced by a group if its members conform to some behavioral regularity, believing that they ought to do so. More precisely, The Concept of Law explains that group acceptance of a social rule involves "a critical reflective attitude to certain patterns of behaviour as a common standard, [which attitude] display[s] itself in criticism (including self-criticism), demands for conformity, and in acknowledgements that such criticism and demands are justified." 37 Yet more precisely, Hart tells us in the Postscript, the social rules foundational to law are conventions. ${ }^{38}$ Conventions are social rules with the special property that each person's acceptance of the rule hinges on its general acceptance, as contrasted with the case where everyone in a group accepts a rule but would be prepared to do so even if the others didn't. ${ }^{39}$ The philosopher David Lewis has provided a very influential analysis of this sort of social rule, ${ }^{40}$ and to make clear that this is my refer-

another group. For the nonrelativist, moral facts (whatever they are) are not equivalent to facts about some group's social morality. For one vigorous defense of cognitivism and nonrelativism, see DAVID $O$. BRINK, MORAL REALISM AND THE FOUNDATIONS OF ETHICS (1989).

${ }^{34}$ See Leslie Green, The Concept of Law Revisited, 94 MiCH. L. REV. 1687, 1691-92 (1996).

${ }^{35}$ Kenneth Einar Himma, Inclusive Legal Positivism, in THE OXFORD HANDBOOK OF JURISPRUDENCE AND PHILOSOPHY OF LAW 125, 126 (Jules Coleman \& Scott Shapiro eds., 2002).

${ }^{36}$ See infra notes 79-80 and accompanying text.

${ }^{37}$ HART, supra note 5 , at 57.

38 See id. at $255-56$.

39 See infra note 185 and sources cited therein.

40 See DAVId LeWIS, ConVENTION: A PhilosophiCAl Study (1969). 
ent, not "conventions" in a fuzzier sense, I henceforth use the term "Lewisconvention."

"Primitive" legal systems, for Hart, contain only "primary" social rules: rules that directly govern conduct and make no reference to other rules. ${ }^{41}$ Fully developed legal systems include "secondary," or higher order, rules: rules that have other rules as their content. For example, the rule that Congress has the power to enact rules regulating interstate commerce is a secondary rule. The rule of recognition is a very special secondary rule. As understood by Hart, it provides validity criteria that, directly or indirectly, determine the legal status of all other rules, secondary and primarycriteria that determine whether other putative secondary and primary rules really are legal rules. ${ }^{42}$ Hart's very rough statement of the rule of recognition for England is: "[W] hat the Queen-in-Parliament enacts is law."43 This rule directly validates the statutes that the Queen in Parliament enacts, and indirectly validates the rules that are validated by those statutes-for example, an administrative regulation enacted by an agency created by statute. On the Hartian account, a very rough statement of the rule of recognition for federal law in the U.S. would be: The text of the 1787 Constitution (including the amending clause), and whatever is validated as law by that text (including both amendments to the original text and subordinate law, e.g., statutes enacted pursuant to Article I or judicial directives issued pursuant to Article III), is law. ${ }^{44}$ This statement would need much refinement because it does not allow for nontextual sources of constitutional law, ${ }^{45}$ or address interpretive standards. ${ }^{46}$ Still, it helps clarify what Hart meant by the rule of recognition, and what that might be in the U.S. context.

So the rule of recognition is a secondary social rule, specifically a Lewis-convention, that undergirds and unifies a legal system by providing validity criteria to determine what the other rules of the system are. Like any social rule, for Hart, the rule of recognition is constituted by the activity of a group of people - by their behavior, preferences, beliefs, and so on. But what group is that? Although the Postscript to the Concept of Law suggests that judges are the recognitional community whose activities constitute the rule of recognition, ${ }^{47}$ the fuller discussion in the original volume is most straightforwardly read (and has generally been read by Hart interpret-

41 See HART, supra note 5, at 90-94.

42 See id. at $94-110$.

43 Id. at 107.

${ }^{44}$ See Kent Greenawalt, The Rule of Recognition and the Constitution, $85 \mathrm{MICH}$. L. REV. 621, 63045 (1987).

45 See supra note 25 and accompanying text.

46 See Greenawalt, supra note 44 , at $654-58$.

47 See HART, supra note 5, at 256. 
ers) to say that this rule supervenes on official practice, nonjudicial as well as judicial. ${ }^{48}$

I will quote the crucial passage in a moment, but to clarify its full significance for readers not already versed in Hart, I should underscore Hart's distinction between accepting a rule and merely obeying it. ${ }^{49}$ A group accepts a social rule if its members engage in certain behaviors with a "critical reflective attitude" towards those behaviors, namely they have a shared sense of a standard requiring those behaviors, and the members of the group genuinely believe the standard to be binding. Someone merely obeys a rule if she conforms to the standard, for example out of fear of sanction, or sheer habit, but does not accord it normative force. This distinction between obedience and acceptance is intuitive. A little less intuitive, but crucial, is the point that the content of a social rule is given by the practices of those who accept it, not those who merely obey it. Behavior itself can be described in multiple ways. ${ }^{50}$ A social rule, such as the rule of recognition, has determinate content only because there is behavior that some individuals engage in, taking as normative a particular standard (which they can grasp, if perhaps not exhaustively articulate $)^{51}$ requiring that behavior.

Now the passage. In a mature legal system, officials must accept the rule of recognition. The rule of recognition is whatever ultimate, secondary rule they do accept. Citizens may accept the rule of recognition, but need not. It may instead be the case that some or even most citizens merely obey the laws validated by the rule of recognition, out of fear or habit, and lack a full grasp of the rule's content.

There are therefore two minimum conditions necessary and sufficient for the existence of a legal system. On the one hand, those rules of behavior which are valid according to the system's ultimate criteria of validity must be generally obeyed, and, on the other hand, its rules of recognition specifying the criteria of legal validity ... must be effectively accepted as common public standards of official behavior by its officials. The first condition is the only one which private citizens need satisfy: they may obey each "for his part only" and from any motive whatever; though in a healthy society they will in fact often accept these rules as common standards of behavior and acknowledge an obligation to obey them .... The second condition must also be satis-

48 See Green, supra note 34, at 1700-02; Kenneth Einar Himma, Making Sense of Constitutional Disagreement: Legal Positivism, The Bill of Rights, and the Conventional Rule of Recognition in the United States, 4 J.L. SOC'Y 149, 152-56 (2003); Waldron, All We Like Sheep, supra note 30, at 180. But see JOSEPH RAZ, THE AUTHORITY OF LAW: EsSAYS ON LAW AND MORALITY 92 (1979) (discussing Hart's ambiguity about the identity of the recognitional community, and reading his statement that the rule depends on "official" behavior to mean the behavior of "law-applying officials").

49 See HART, supra note 5, at 110-17.

50 See Jules L. Coleman, The Practice of Principle: In Defense of a Pragmatist APProach TO LEGAL THEORY 80 (2001).

51 See COLEMAN, supra note 50, at 81; MATTHEW H. KRAMER, WHERE LAW AND MORALITY MEET 110-11 (2004); Waldron, All We Like Sheep, supra note 30, at 177-78. 
fied by the officials of the system. They must regard [the rule of recognition] as [a] common standard[] of official behavior and appraise critically their own and each other's deviations as lapses. ${ }^{52}$

In short, "[ $t]$ he assertion that a legal system exists is therefore a Janus-faced statement looking both towards obedience by ordinary citizens and to the acceptance by officials of secondary rules as critical common standards of official behavior." 53

Les Green summarizes Hart's position thus: "[F]or Hart, the only consensus necessary for law is a consensus of elites." ${ }^{54}$ I'd amend this to: "For Hart, elite consensus defines law." Hart's position, as I understand it, is not merely that the rule of recognition must be accepted by officials and may, but need not, be accepted by citizens. This formulation suggests, misleadingly, that the rule is somehow external to practice, and that officials have no priority in determining the rule's content. Rather, Hart's view is that whatever ultimate, secondary rule officials do accept just is the rule of recognition; citizens might also accept it, but their actions, beliefs, judgments, and verbalizations have no role in determining its content. Officials, not citizens, are the recognitional community: that is, the rule of recognition supervenes on official actions, beliefs, judgments, etc., alone. ${ }^{55}$

One difficulty for this view, of course, is that being an "official" is itself a legal status. Aren't "officials" of a legal system governing a territory just those persons accepted as such by most people within the territory, citizens and subjects included? So doesn't citizen or subject, not just official, acceptance have to be partly constitutive of the legal system? ${ }^{56}$ But the Hartian may be able to parry this objection-for example, by saying that a legal system exists if (1) some rule of recognition is (2) accepted by some persons, who (3) have the status of "official" pursuant to the rule of recognition they accept, and (4) the primary rules validated by the rule of recognition are generally complied with. ${ }^{57}$ In any event, I think it is pretty clear, as a matter of Hart exegesis-my only concern, at this point-that Hart believed official practice, not citizen or subject practice, to be constitutive of the rule of recognition and thereby to provide the ultimate criterion of legal truth.

52 HART, supra note 5, at 116-17.

53 Id. at 117 .

54 Green, supra note 34, at 1702.

55 See Himma, supra note 48 , at $154 \mathrm{n}, 8$ ("'C]itizens . . . are not participants in conventional legal practice and hence do not directly figure, as a conceptual matter, into the existence conditions for a rule of recognition.").

56 On this problem, see EeriK Lagerspetz, THE OPPOSITE MirRoRs: AN ESSAY on the CONVENTIONALIST THEORY OF INSTITUTIONS 158-60 (1995).

57 See Coleman, supra note 50, at 101; Christopher Kutz, The Judicial Community, 11 PHIL. ISSUES 442, 462 (2001). 
Why would Hart identify official, not citizen or subject, practice as the substratum for law? I think the answer relates to Hart's descriptivism. ${ }^{58}$ "My account," Hart confirms in the Postscript, is "descriptive in that it is morally neutral and has no justificatory aims; it does not seek to commend on moral or other grounds the forms and structures which appear in my general account of law." 59 Our ordinary, descriptive concept of law encompasses legal systems, such as the Soviet Union's, in which much of the citizenry is alienated from the primary rules and conforms without accepting them in any robust sense. And it surely encompasses legal systems where private citizens, busy with their own lives, know (by deferring to legal experts) what the primary rules are, and generally accept those, but don't have any clear sense of the secondary rules that validate the primary rules as law. "[T]he reality of the situation is that a great proportion of ordinary citizens-perhaps a majority - have no general conception of the legal structure or its criteria of validity." ultimate, secondary rule accepted by the citizenry would preclude a legal system with an alienated citizenry, and would seem to make the rule virtually vacuous in less dysfunctional systems where most citizens are (rationally) ignorant of secondary legal matters.

On the other hand, some group must accept the rule of recognition. There is no legal system unless the right sort of secondary rule is practiced and accepted by some group. It is tempting to think that judges must be the group, since they apply the law. This thought tempts Hart in the Postscript, but The Concept of Law resists the temptation, since (after all) enforcement officials also apply law ${ }^{61}$ as must legislators in determining what they are empowered to enact. Dworkin is obsessed with adjudication; Hart is not. Hart is also careful to resist the quasi-Austinian notion that legislators are the ultimate legal authorities. ${ }^{62}$ If not around legislators alone or judges alone, the only natural place left to draw the line defining the recognitional community is around the group of all officials.

Various positivists since Hart have drawn the line in the same place. Jules Coleman, in his famous 1982 article Negative and Positive Positivism, ${ }^{63}$ argues that the rule of recognition can incorporate moral standardsadvancing the view now called "soft positivism," later explicitly endorsed

58 See Stephen R. Perry, Hart 's Merhodological Positivism, in HART'S POSTSCRIPT: ESSAYS ON THE POSTSCRIPT TO THE CONCEPT OF LAW 311, 319-31 (Jules Coleman ed, 2001) [hereinafter HART'S POSTSCRIPT] (discussing Hart's descriptivism).

59 HART, supra note 5, at 240.

${ }^{60}$ Id. at 114 .

61 See Himma, supra note 48 , at 154.

62 See HART, supra note 5, at 18-78 (criticizing Austinian view of law as the coercive order of the sovereign); id. at 106 (distinguishing Hart's rule-of-recognition account from the view that "somewhere, in every legal system, ... there must be a sovereign legislative power which is legally unlimited").

63 Jules Coleman, Negative and Positive Positivism, 1 J. LEGAL STUD. 139 (1982). 
by Hart in the Postscript. ${ }^{64}$ Coleman, like Hart, sees the rule of recognition as a rule grounded in official practice: "The form of . . positivism I want to characterize and defend has, at its point, ... [t] hat the authority of law is a matter of its acceptance by officials." 65 Coleman's views about positivism, as articulated most recently and comprehensively in his book The Practice of Principle, have evolved; he now denies that the rule of recognition is necessarily a Lewis-convention, and instead sees it as a different kind of social fact, namely a "shared cooperative activity" ("SCA") ${ }^{66}$ I will explore the difference between Lewis-conventions and SCAs in Part II. The point to emphasize here is that the shift from Lewis-conventions to SCAs has not changed Coleman's understanding of the contours of law's recognitional community:

Like every legal positivist, I maintain that the possibility of law is to be explained in terms of social facts. Like Hart, I further maintain that the possibility of legal authority is to be explained in terms of . . . the adherence by officials to a rule of recognition that imposes a duty on them to apply all and only those rules valid under it. ${ }^{67}$

Scott Shapiro has elaborated the notion of law as a kind of SCA. He sees a legal system, roughly, as the product of "legal participants" who "are ... committed to doing their part in creating or maintaining a unified system of rules." "P8 "Participants," here, are officials, not citizens or subjects.

If the claim that legal practice is [an SCA] has any chance of being true, then the class of participants will have to be restricted to legal officials. This is so because there are legal systems where large segments of the population conform to the law out of nothing more than fear of punishment ....

To be sure, many ordinary citizens consider the law to be legitimate and willingly obey those in authority. However, even in these cases, it strains ordinary usage to describe these individuals as "participants in the legal system." The business of law is the creation and exercise of authority, and its participants are the officials who operate the levers of legal power. ${ }^{69}$

Andrei Marmor denies that law is grounded either on Lewisconventions or SCAs, proposing instead that the rule of recognition is a "constitutive" rule. ${ }^{70}$ The jurisprudents' debate about the precise kind of

64 See HART, supra note 5, at 250-54. For an overview of recent debates about "soft" or "inclusive" positivism, see Himma, supra note 35; Andrei Marmor, Exclusive Legal Positivism, in THE OXFORD HANDBOOK OF JURISPRUDENCE AND PHILOSOPHY OF LAW, supra note 35, at 104-24.

${ }^{65}$ Coleman, supra note 63 , at 148 .

66 See COLEMAN, supra note 50, at 94-100.

${ }^{67}$ Id. at 77 .

68 Scott J. Shapiro, Law, Plans, and Practical Reason, 8 LEGAL. THEORY 387, 426 (2002).

69 Id. at 418 .

70 See Andrei Marmor, Legal Conventionalism, 4 LEGAL THEORY 509 (1998). 
social fact that law involves mirrors broader philosophical debates about social reality. While Hart's Postscript draws, in effect, on David Lewis, and the Coleman/Shapiro notion of SCAs explicitly relies on the philosopher Michael Bratman, Marmor's "constitutive" understanding of the rule of recognition applies John Searle's famous notion of "constitutive" rules to the realm of law. ${ }^{71}$ Still, officials remain primary in Marmor's account. $\mathrm{He}$ writes:

What we would normally see [with constitutive rules] is . . a core of practitioners whose practices and self-understandings determine, to the greatest extent, what the [rule of recognition] is, and further groups of people in outer circles, whose knowledge of the [rule of recognition] is much more partial, and whose influence on its content is relatively marginal. ${ }^{72}$

When it comes to law, officials, particularly judges and, next, legislators, are in this "core"; citizens are banished to the outer circles. ${ }^{73}$

In short, Hart as well as some successor positivists such as Coleman, Shapiro, and Marmor identify officials as the group whose practices undergird law. Other positivists, however, see judges rather than officials more generally as the recognitional community. Joseph Raz, in his book The Concept of a Legal System, a major work from the first generation of postHartian positivist scholarship, quotes with approval Salmond's dictum that " $[t]$ he law consists of the rules recognized and acted on by courts of justice," $" 74$ and elaborates,

Salmond's main contention is sound. Not every law is created by law-creating organs, and though the importance of legislation as a law-creating method is characteristic of modern legal systems, it is not characteristic of every legal system, nor is any other law-creating method. On the other hand, it can be said that every legal system institutes law-applying organs which recognize every law of the system. ${ }^{75}$

Raz therefore proposes the following criterion for determining the content of a legal system: "A . . . legal system contains all, and only all, the laws recognized by a primary law-applying organ which it institutes," where a "primary law-applying organ" is, roughly, a court. ${ }^{76}$ Chris Kutz has elaborated this idea in his recent work, aptly titled The Judicial Community."

${ }^{71}$ See id. at 522 n.26. See generally infra notes 113-121, 175-177, 185-186 and accompanying text (discussing Bratman's, Searle's, and Lewis's accounts of social reality and applications by jurisprudents).

72 Marmor, supra note 70, at 524.

${ }^{73}$ See id. at 525 . Another contemporary positivist who views the rule of recognition as an official practice is Matthew Kramer. See, e.g., KRAMER, supra note 51, at 104-10.

74 JOSEPH RAZ, THE CONCEPT OF A LEGAL SYSTEM: AN INTRODUCTION TO THE THEORY OF LEGAL SYSTEM 190 (2d ed. 1980).

75 Id. at 191.

${ }^{76} \mathrm{Id}$. at 192. A similar view is presented in RAZ, supra note 48, at 78-121.

${ }^{77}$ Kutz, supra note 57. 
Kutz, like Jules Coleman and Scott Shapiro, sees law as resting on a kind of SCA among a privileged group. For Coleman and Shapiro, the individuals whose SCA creates law are officials; for Kutz, by contrast, the canonical group consists of judges.

Here is the model: a legal system consists of a set of individuals each intentionally doing his or her part in a collective project of establishing a set of criteria for distinguishing those norms that have a privileged status in social ordering from other social norms, and determining the proper application of the privileged norms, plus institutions for generating and revising the privileged norms, plus some extensive set of social practices in a population governed effectively by the norms. ... So, even more simplified, the model is this: A legal system consists of a set of judges, each intentionally contributing to the systematic distinction of legal from non-legal norms and regulating their application, plus other institutions capable of generating and enforcing those norms. $^{78}$

Let us turn now to Dworkin. I will focus on the most complete statement of Dworkin's jurisprudential views, Law's Empire. Dworkin in this work proposes an "interpretive" conception of legal content. ${ }^{79}$ This conception says: In any legal system, real legal rights, duties, etc. are those identified by the best "interpretation" of the preinterpreted legal practices. Think of an "interpretation" as a kind of constructed rule of recognition. It offers criteria for legal validity but, unlike the Hartian rule of recognition, the best "interpretation" for some legal system need not-indeed almost surely will not-faithfully mirror the actual practices of judges, officials, citizens, or some other recognitional community within that system.

Rather, Dworkin famously proposes two dimensions for evaluating the quality of "interpretations": "fit" and moral "justification." A candidate "interpretation" that fits well with the preinterpreted practices, but does poorly on the "justification" dimension--that constitutes a morally unattractive scheme of social organization-may be worse, all things considered, than another "interpretation" that is better morally justified but meshes somewhat less well with the preinterpreted data. As Dworkin summarizes:

Judges who accept the interpretive ideal of integrity decide hard cases by trying to find, in some coherent set of principles about people's rights and duties, the best constructive interpretation of the political structure and legal doctrine of their community. They try to make that complex structure and record the best these can be. It is analytically useful to distinguish different dimensions or aspects of any working theory. It will include convictions about both fit and justification. Convictions about fit will provide a rough threshold requirement that an interpretation ... must meet if it is to be eligible at all... .

\footnotetext{
${ }^{78} I d$. at 461.

${ }^{79}$ For an accessible summary of Dworkin's account of law, with citations to the literature on Dworkin, see BRIAN BIX, JURISPRUDENCE: THEORY AND CONTEXT 81-92 (2d ed. 1999).
} 
Hard cases arise, for any judge, when his threshold test does not discriminate between two or more interpretations of some statute or line of cases. Then he must choose between eligible interpretations by asking which shows the community's structure of institutions and decisions-its public standards as a whole-in a better light from the standpoint of political morality. . . . Questions of fit arise at this stage of interpretation as well, because even when an interpretation survives the threshold requirement, any infelicities of fit will count against it ... 80

So law for Dworkin, by contrast with the positivists, is essentially moralized. Positivists in the "soft positivist" camp, paradigmatically Hart and Coleman, recognize that the rule of recognition followed by officials might incorporate moral considerations, but they insist that the rule need not do so. Dworkin, by contrast, insists that his master rule for any legal system necessarily reflects moral considerations, since the dimension of moral justification is necessarily one dimension for evaluating putative master rules. But--to flip the point around-so, too, is the "fit" dimension. On the interpretive conception of law, the true master-rule for any system, necessarily, is one that sufficiently "fits" the preinterpreted practices of that system. That is the sense in which, for Dworkin as for the positivists, law is a matter of social fact.

But what exactly are the social facts or practices that ground law-that an "interpretation" should aim to "fit," if not perfectly then at least sufficiently well and ceteris paribus? Dworkin, at various points in Law's Empire, suggests that "interpretations" should aim to fit the past political and legal decisions of a community. ${ }^{81}$ Indeed, at a crucial juncture in the book, he seems to say that any conception of law (his interpretive conception, or any other) will involve some nexus to the past.

[T] he most abstract and fundamental point of legal practice is to guide and constrain the power of government in the following way. Law insists that force not be used or withheld . . except as licensed or required by individual rights and responsibilities flowing from past political decisions about when collective force is justified.

The law of a community on this account is the scheme of rights and responsibilities that meet that complex standard: they license coercion because they flow from past decisions of the right sort. ${ }^{82}$

Yet past political or legal "decisions" are not self-identifying. What distinguishes a genuine, historical Supreme Court opinion or congressional enactment that a candidate "interpretation" of U.S. practice should aim to fit, from a void or fake opinion or enactment? Dworkin's answer, the natural one, seems to be that present understandings identify the past events that

\footnotetext{
80 RONALD DWORKIN, LAW'S EMPIRE 255-56 (1986).

81 See, e.g., id. at 96, 188, 238-39, 255.

82 Id. at 93.
} 
"interpretations" should aim to fit: the events that are part of the preinterpreted legal data.

History matters in law as integrity: very much but only in a certain way. Integrity does not require consistency in principle over all historical stages of a community's law; it does not require that judges try to understand the law they enforce as continuous in principle with the abandoned law of a previous century or even a previous generation. It commands a horizontal rather than vertical consistency of principle across the range of the legal standards the community now enforces. ${ }^{83}$

In short: "Law as integrity, then, begins in the present and pursues the past only so far as and in the way its contemporary focus dictates." 84

So let us provisionally understand Dworkin thus. For any legal system, the genuine law (at any time $T^{*}$ ) of the system is the set of legal rights, duties, etc., identified by a constructed rule of recognition that is best, all things considered, both with respect to moral justifiability and in fitting the present (at $T^{*}$ ) understandings of some group of persons about what the law of the system is. ${ }^{85}$ Specifically, genuine U.S. law at present is identified by a constructed rule of recognition that integrates considerations of straight moral justifiability with the present, preinterpretive understanding of U.S. law shared by some group of persons. But what group is that? Judges? Officials? Citizens? Some other group?

One passage in Law's Empire suggests that Dworkin's recognitional community is a community of lawyers. He writes:

Law cannot flourish as an interpretive enterprise in any community unless there is enough initial agreement about what practices are legal practices so that lawyers argue about the best interpretation of roughly the same data. . . I do not mean that all lawyers everywhere and always must agree on exactly which practices should count as practice of law, but only that the lawyers of

83 Id. at 227.

$84 \mathrm{Id}$; see also id. at 91 (stating that "the lawyers of any culture where the interpretive attitude succeeds must largely agree [as to what practices are legal practices] at any one time." (emphasis added)).

${ }^{85}$ This presentist reading of Dworkin could certainly be challenged. If a community of equals reaches decisions over time, doesn't each past decision exert gravitational force on present "interpretations"-force that cannot be dispelled merely by regarding the past decisions as now void or even fake? Yet the problem here, of presentism versus historicism in reading Dworkin, is orthogonal to the problem of deep popular constitutionalism versus official supremacy. What might a historicist reconstruction of Dworkin's view say? I suppose it might say: The best "interpretation" of U.S. law should sufficiently fit all past events that, at their time of occurrence, were regarded by U.S. judges or U.S. officials as having legal status. Or instead it might say: The best "interpretation" of U.S. law should sufficiently fit all past events that, at their time of occurrence, were regarded by U.S. citizens as having legal status. As between these two historicisms, the latter is more consistent- I want to suggest-with Dworkin's associative view of citizens as full members of political communities and obligated by its laws. See infra text accompanying notes 89-91 (arguing that Dworkin's associative picture implies deep popular constitutionalism). 
any culture where the interpretive attitude succeeds must largely agree at any one time. ${ }^{86}$

Yet this lawyerly construal of Dworkin's recognitional community is in tension with his defense of the interpretive conception of law: a defense that invokes the value of integrity and the notion of associative obligation. Why should judges care about both fit and moral justification, rather than fit alone (in effect, the positivist view) or moral justification alone (a pure natural law view)?

Dworkin's answer, brutally condensed, is this: (1) In the right sort of political community (one where most members share a sense that they have special responsibilities to each other, a sense that these flow from an underlying obligation to be concerned about each other's well-being, and a sense that group members are all equals), genuine associative or fraternal obligations between the members can arise. These associative obligations are moral obligations that will, at least prima facie, make the community's decisions morally authoritative for its members, and morally legitimate the community's use of coercion. (2) A community which accepts and practices the value of "integrity" will realize the conditions of associative obligation just stated (assuming the community is not too unjust). Integrity requires that the community's decisions be more than mere pragmatic compromises, instead maintaining a principled consistency with past decisions. On my presentist reading of Dworkin, this means: principled consistency with those past events recognized as legal decisions by the members' present shared understanding of the law. In such a community, members may not actually possess the attitudes just described, but the practice of integrity "expresses" those attitudes. "[A] general commitment to integrity expresses a concern by each for all that is sufficiently special, personal, pervasive, and egalitarian to ground communal obligations ...."87 (3) Concretely, what the value of integrity requires is Dworkinian interpretation. Legal actors, both judges and other actors, practice integrity just by attempting to identify and apply (as far as they can) the constructed rule of recognition that is best, all things considered, with respect to the two dimensions of fit and moral justification. ${ }^{88}$

The capsule summary just provided compresses arguments provided by Dworkin over many pages of Law's Empire, and is no doubt dramatically over simplified. But there is no denying, I think, that Dworkin links his "interpretive" view of legal content to an idealized kind of political community, one where the members are responsive, in a morally principled way, to each other. "Interpretation" just is the requisite responsiveness.

\footnotetext{
${ }^{86}$ DWORKIN, supra note 80, at 90-91.

${ }^{87}$ Id. at 216 .

${ }^{88}$ See id. at 164-258.
} 
[The best model] insists that people are members of a genuine political community only when they accept that their fates are linked in the following strong way: they accept that they are governed by common principles, not just by rules hammered out in political compromise. ... Members of a society of principle accept that their political rights and duties are not exhausted by the particular decisions their political institutions have reached, but depend, more generally, on the scheme of principles those decisions presuppose and endorse....

[Such a] community . . . can claim the authority of a genuine associative community and can therefore claim moral legitimacy - that its collective decisions are matters of obligation and not bare power-in the name of fraternity. ${ }^{89}$

The key point, for my purposes, is that Dworkin's associative or fraternal defense of "interpretation" suggests an inclusive conception of the recognitional community. According to Dworkin, the very process of "interpretation" generates the conditions for associative obligation. The very fact that community members determine what they ought to do by synthesizing the community's preinterpreted practices with moral considerations is expressive of the propositions that community members owe special obligations to each other, are responsible for each other's well-being, and have equal concern and respect for each other. ${ }^{90}$ Imagine, then, a community in which the preinterpreted data consist in judicial or official rather than citizen understandings of what the law is; individual community members (judges, officials, and perhaps citizens) identify legal requirements by ascertaining the constructed rule of recognition that best fits this data and is best morally justified. How would that practice, without more, communicate the mutual duties and equal status of citizens (not just judges and officials), thereby creating genuine associative moral obligations for citizens and justifying the coercion of citizens?

Dworkin's recognitional community presumably must be the collectivity of all citizens, not merely lawyers, judges, legislators, or officials, for otherwise it is very hard to see how "a general commitment to integrity," as such, "expresses a concern by each for all that is sufficiently special, personal, pervasive, and egalitarian to ground communal obligations." It is true that a legal system with an official- or judge-composed recognitional community might contingently express, or actually possess, the attitudes of special duty, reciprocal responsibility for well-being, and equal respect that generate associative moral obligations for all citizens. But Dworkin's argument is different: it is that the practice of integrity, in itself, generates those obligations (assuming the community is not too unjust). And that implies a very different conception of the recognitional community than the positivists'. Law-as-integrity generally obligates private citizens in the as-

\footnotetext{
89 Id. at $211-14$.

90 See id. at $186-90,213-16$.
} 
sociative or fraternal way that Dworkin describes only if private citizens are members of the community whose practices provide the preinterpreted data that "interpretations" seek to fit and justify.

In short, Dworkin is a deep popular constitutionalist. On the Dworkinian account, U.S. law at present is identified by a constructed rule of recognition that integrates considerations of straight moral justifiability with the preinterpretive understanding of U.S. law held at present by U.S. citizens: a shared, contemporaneous citizen understanding that, in turn, will identify certain past events as legal decisions (as "acts of Congress," "Supreme Court decisions," etc.).

My deep popular constitutionalist reading of Dworkin's Law's Empire is surely contestable-more contestable than the official-centered reading of Hart's Concept of Law. Law's Empire does not say explicitly that the group whose preinterpreted legal practices undergird U.S. law is the collectivity of all U.S. citizens. Rather, as I have just suggested, that inclusive view of the U.S. recognitional community is a natural inference from Dworkin's argument for why all U.S. citizens have a moral obligation to obey U.S. law. The deep popular constitutionalist reading is also in apparent conflict with other, less democratic aspects of Dworkin's thought: specifically (1) the notion that constitutional rights "trump" decisions of majoritarian legislatures $;{ }^{92}$ (2) a broad reading of some of the rights-bearing provisions of the Constitution, particularly the Fourteenth Amendment; ${ }^{93}$ (3) Dworkin's "activist" view of adjudication, which holds that judges need not defer to majoritarian legislatures in enforcing the rights-bearing provisions of the Constitution; $;{ }^{94}$ and (4) his apparent acceptance of Cooper v. Aaron. ${ }^{95}$ I will not explore Dworkin's complex defense of these various views; that would take us too far afield. Suffice it to say that all are consistent with deep popular constitutionalism. ${ }^{96}$

${ }^{91}$ Clearly, Dworkin does think that law-as-integrity can obligate, and justify coercion against, private citizens-not merely judges and other officials. For example, he writes:

A state is legitimate if its constitutional structure and practices are such that its citizens have a general obligation to obey political decisions that purport to impose duties on them. ... I shall argue that a state that accepts integrity as a political ideal has a better case for legitimacy than one that does not.

Id. at 191-92. And, in sketching his ideal of a political community that triggers associative obligations, Dworkin repeatedly describes citizens as members of that community, engaged in the practice of integrity. For example: "Integrity ... insists that each citizen must accept demands on him, and may make demands on others, that share and extend the moral dimensions of any explicit political decisions. Integrity ... fuses citizens' moral and political lives ...." Id. at 189.

92 See, e.g., RONALD DWORKIN, TAKING RIGHTS SERIOUSLY 132-33 (1978).

93 See, e.g., RONALD DWORKIN, FREEDOM's LAW 36 (1996) (noting that he believes abortion, pornography, flag burning, and "Nazi marchers" to be constitutionally protected).

${ }_{94}$ See, e.g., DworkIN, supra note 92 , at $131-49$.

95 See DWORKIN, supra note 93 , at 35.

96 The "rights as trumps" view can rest on a nonutilitarian moral view that sees rights as moral constraints on social welfare, or simply on the shared understanding in the legal culture, among citizens and 
A different objection is that my talk of citizen versus official roles in defining the preinterpreted legal data is a red herring. Everyone agrees, citizens and officials alike, on what the basic sources of law are. The controversy comes at the interpretive stage, in identifying fitting-and-justified interpretations, not before. To quote Dworkin:

In fact we have no difficulty identifying collectively the practices that count as legal practices in our own culture. We have legislatures and courts and administrative agencies and bodies, and the decisions these institutions make are reported in a canonical way. In the United States we have the Constitution as well. ... Our culture [preinterpretively] presents us with legal institutions and the idea that they form a system. ${ }^{97}$

But surely, once we reach even slightly more esoteric matters, the shared understandings of a narrower recognitional community, limited to officials, could well be different from (for example, thicker than) those of a broader, citizen community. ${ }^{98}$ Admittedly, Dworkin in Law's Empire never discusses how "interpretation" should proceed when more inclusive subsets of the citizenry generate different preinterpreted legal data than less inclusive subsets. Which set of data should the interpretation fit? The argument I have been pressing is that Dworkin's picture of associative obligation points towards an inclusive understanding of the recognitional community.

officials, that there is a Bill of Rights and it constrains legislation. The broad reading of the Fourteenth Amendment can be grounded again in citizen and official acceptance of the constraining force of that Amendment, plus the breadth of the provision's language, plus the plausible claim that the kind of originalism which reads the language more narrowly (for example, narrowing the scope of the Amendment to track its Framers' particular conceptions of the broad notions of "equality," "liberty" and "process") is not so deeply embedded in preinterpreted practices as to override the moral objections against it.

Finally, and crucially, Dworkin's nondeferential view of constitutional judging and his acceptance of Cooper need only invoke the view that judges are better at moral reasoning than legislators and the private citizens to whom legislators are especially responsive. Differential judicial moral expertise would support nondeferential constitutional adjudication either because constitutional adjudication at many junctures reduces to straight moral reasoning, or simply because, like all legal decisionmaking, it is appropriately "interpretive" at some point and therefore responds to considerations of moral "justification" as well as "fit." In short, if judges do indeed possess special moral expertise, then Dworkin can plausibly conclude that the best "interpretation" of U.S. practice-the constructed rule of recognition for our system-requires (shallow) judicial supremacy. But that conclusion is perfectly consistent with the view that judicial practice lacks any privileged role in defining the preinterpretive understandings that orient Dworkin's "fitness" dimension. See infra text accompanying notes 270-274 (noting that shallow judicial supremacy is consistent with deep popular constitutionalism).

97 DWORKIN, supra note 80, at 91.

98 Notably, Dworkin includes not just legal institutions and their decisions, but legal propositions, in the preinterpreted data that Dworkinian "interpretation" begins with. See id. at 91-92. It also bears emphasis that participants in the U.S. legal system or other systems can disagree about whether some event is a legal decision, and even about which legal institutions exist. See Matthew D. Adler \& Michael C. Dorf, Constitutional Existence Conditions and Judicial Review, 89 VA. L. REV. 1105 (2003) (arguing that the Constitution sets forth "existence conditions," possibly contestable, that determine whether some text or utterance is really a statute, regulation, or some other kind of nonconstitutional law); infra notes 110-111, 178-182, and accompanying text (discussing possibility of disagreement about institutions). 
A different possibility, I suppose, is that Dworkin means to adopt a grouprelative view of law-but this would seriously qualify his famous claim that there are right answers to virtually all legal questions, ${ }^{99}$ because on the group-relative reconstruction of Dworkin there is no right answer to questions of U.S. law simpliciter, only to questions of U.S. law relative to different groups whose varying practices are varying objects for interpretations.

The inclusive reading of Dworkin is not one he explicitly avows, nor one that he must on pain of logical contradiction accept, but I propose it as the best reading - at a minimum, as a plausible reading. That minimal proposal is borne out by Dworkin's paean to the citizen perspective and description of law as "protestant" in the closing sentences of Law's Empire. Dworkin writes:

What is law? ... Law is not exhausted by any catalogue of rules or principles, each with its own dominion over some discrete theater of behavior. Nor by any roster of officials and their powers each over part of our lives. Law's empire is defined by attitude .... We studied that attitude mainly in appellate courts, where it is dressed for inspection, but it must be pervasive in our ordinary lives if it is to serve us well even in court. It is an interpretive, selfreflective attitude addressed to politics in the broadest sense. It is a protestant attitude that makes each citizen responsible for imagining what his society's public commitments to principle are, and what these commitments require in new circumstances. The protestant character of law is confirmed, and the creative role of private decisions acknowledged, by the backward-looking, judgmental nature of judicial decisions, and also by the regulative assumption that though judges must have the last word, their word is not for that reason the best word. ${ }^{100}$

Given this language, and more generally Dworkin's explication of how interpretive practice as such can transform a community and generate moral obligations for all of its citizens, not just its judges or officials, the inclusive reading of Dworkin is (at a minimum) natural and plausible. This point suffices for my underlying purpose in this Part, which is to show that the problem of the recognitional community has recurred in jurisprudential scholarship from Hart onwards, and that no consensus answer to this problem has emerged. Hart and some successor positivists identify the recognitional community with officials; but there are positivists, such as Raz and Kutz, who construe it more narrowly; and Dworkin (plausibly) should be seen to construe it more inclusively. Dworkin (plausibly) turns out to be a deep popular constitutionalist-a view that is consistent, I have suggested, with his (shallower) commitment to judicial supremacy and with other nonmajoritarian aspects of his thought. And (plausibly) there is a second Hart-Dworkin debate, about the role of citizens at the recognitional stage,

99 See infra text accompanying notes 257-258.

${ }^{100}$ See DwORKIN, supra note 80, at 413. 
which accompanies their famous debate about the nexus between law and morality.

\section{A GROUP-RELATIVE VIEW OF LAW}

I now propose a deflationary solution to the problem of the recognitional community. Dworkin, Hart, and positivists since Hart, such as Coleman, Shapiro, Kutz, and Marmor, disagree about the identity of the recognitional community whose practices undergird law (judges versus officials versus citizens); about the precise nature of those practices (Lewisconventions versus SCAs versus "constitutive" rules); and about whether law is a function of those practices plus moral considerations (Dworkin) or merely the practices (the positivists). But there is virtually universal agreement that, in each legal system, there is a single canonical recognitional community the social facts about which determine (perhaps along with morality) the law of that system.

My proposal is to drop this premise. Law, I suggest, is "grouprelative."

Legal norms, everyone agrees, are grounded in social practice. In effect, law is a special kind of social norm. It has long been understood that social practice can ground nonlegal norms: norms of dress, manners, sexual behavior, and so on. Hart's great insight was to realize that the deficiencies of the Austinian view of law could be remedied by understanding legal norms, too, as social: specifically, as norms derived from a particular social practice - the rule of recognition.

Nonlegal social norms are obviously group-relative. Clearly, different groups can have different nonlegal norms governing the very same action. This is true because nonlegal norms supervene on a group's members' mental states and behaviors, which can vary from group to group, and because the scope of a group's nonlegal norms need not be limited to the actions of group members. ${ }^{101}$ It is thus conceptually confused, a category mistake, to presuppose that there is a single, canonical manner of dress, eating, or sexual behavior that is "socially appropriate" for a given person at a given time. Social "oughts" are defined by group practice. A claim about what someone should do, socially speaking, is not true or false simpliciter, but is rendered true or false by the activities, beliefs, preferences, intentions, utterances and so forth of the members of some group, and can be true relative to one group but false relative to another. My proposal is to extend this group-relative understanding of social "oughts" from nonlegal "oughts" to law itself.

101 Further, groups can overlap. See, e.g., Gilbert HaRman, THE NATURE OF MORALity: AN INTRODUCTION TO ETHICS 113 (1977) ("Moralities are social. They are defined by the conventions of groups. But you belong to more than one group, and different groups have different conventions."). 
In the interests of giving scholarly credit, and of persuading the reader that the group-relative view of law I am about to elaborate and defend at length is not so lunatic as to be rejected out of hand, I will note that Joseph Raz adumbrates a group-relative view of law in his work The Concept of a Legal System. As already discussed, Raz in that work sees law as grounded in the practices of courts (or, to use his terminology, "primary law-applying organs"). After writing that a "legal system contains all, and only all, the laws recognized by a primary law-applying organ which it institutes,"102 Raz comments:

It may be found necessary to conceive of a legal system not as a set of laws recognized by all the primary law-applying organs instituted under it-as is implied in this criterion-but as a set of substantially, but only partly overlapping, sets of laws, each recognized by one or more of the organs instituted under it. The proposed criterion of membership can be relaxed to take account of this need. The various ways in which this can be done will not be explored here. ${ }^{103}$

Raz's suggestion is that different judges might recognize each other as parts of the same legal system (in the sense that each judge's practices identify herself and the other judges as "judges" within the same legal system), yet follow practices that define the content of that system in somewhat divergent ways. In short, there can be multiple judicial rules of recognition. My suggestion is that different groups, not merely of judges but also of nonjudicial officials, citizens, and even noncitizen subjects, ${ }^{104}$ can engage in practices that ground systems of law that are linked in some tight way (for example, all the systems apply in the same territory, give substantial weight to the same basic texts, and are referred to using the very same name, e.g., "U.S." law), but nonetheless diverge in their content.

My proposal has general jurisprudential implications, of course, but my aim in this Article is parochial: to contribute to scholarship about popular constitutionalism and judicial supremacy under the United States Constitu-

102 RAZ, supra note 74, at 192.

${ }^{103}$ Id ; see also LAGERSPETZ, supra note 56, at 161-66 (discussing the possibility of multiple rules of recognition). Hart, too, notes this possibility, but sees the case of a legal system with different official groups espousing different rules of recognition as pathological. See HART, supra note 5, at 122-23. Finally, Matthew Kramer argues that officials can disagree to some extent about the content of the rule of recognition, although he would deny that this means the existence of multiple rules of recognition. See KRAMER, supra note 51, at 105-06.

104 The recent literature about popular constitutionalism focuses on the role of citizens, officials, and judges in constitutional decisionmaking. I am not aware of "shallow" arguments, at least in this literature, to the effect that noncitizens should also play a substantial role in constitutional decisionmaking, or of "deep" accounts that either include noncitizens (within the territory of the U.S., abroad, or both) in the recognitional group, or limit the recognitional group to certain noncitizens (here, abroad, or both). But I see nothing in the group-relative view to rule out such accounts-with the caveats, here as elsewhere, that (1) the posited group must be sufficiently group-like to instantiate the sort of social practice that gives rise to law and perhaps that (2) its conception of constitutional law must be sufficiently "effective." See infra text accompanying notes 243-251, 254-255. 
tion. I will therefore frame the proposal, and defend it, as a proposal about U.S. law. It appears that most participants in U.S. legal debates, officials and citizens alike, now accept and have accepted that a certain text referred to as the "U.S. Constitution" plays a very large role in defining U.S. law. ${ }^{105}$ But there have been live discussions about the content of that canonical text. ${ }^{106}$ More generally, different Americans (let alone aliens) have understood the substance of U.S. constitutional law and, derivatively, U.S. law quite differently: Is the text the exclusive source of U.S. constitutional law? How important are the intentions or meanings of the Framers in guiding interpretation of the text? Does the U.S. Supreme Court have the final word in constitutional controversies, vis-à-vis Congress, the President, or the states? More concretely, is legislation regarding abortion, or school prayer, or firearms, unconstitutional? Does Congress have virtually unlimited regulatory power, or is it tightly circumscribed? ${ }^{107}$

The answers to these questions are group-relative, or so I will suggest. There is no single, canonical recognitional community for U.S. law. Rather, Supreme Court practice will ground one set of answers to the questions, one body of U.S. constitutional law (and derivatively U.S. law); presidential practice, a different body of U.S. constitutional law; state judicial practice, a different body of U.S. constitutional law; citizen practice, perhaps, yet another; noncitizen practice, perhaps, yet another. These bodies of constitutional law share a common anchor in the text of the Constitution and perhaps in lots of other places, too-for example, in their generally convergent understanding of the physical territory governed by U.S. law; ${ }^{108}$

105 See H. Jefferson Powell, A COMmunity Built on Words: The CONSTitution in History AND POLITICS 204 (2002) (pointing to the "axiomatic authority of the text" in constitutional debates).

106 See Harrison, supra note 26, at 376-77 (describing disputes about the validity of the Thirteenth, Fourteenth, and Fifteenth Amendments and stating that these disputes had ceased by 1872, when both major parties accepted all three amendments); Michael Stokes Paulsen, A General Theory of Article V: The Constitutional Lessons of the Twenty-seventh Amendment, 103 YALE L.J. 677, 678-81 (1994) (describing brief public debate about the validity of the Twenty-seventh Amendment).

${ }^{107}$ Scholarly and judicial debates about these matters are intimately familiar to constitutional scholars. For histories that document the role of nonjudicial officials or citizens in various constitutional debates, see, for example, 2 ACKERMAN, TRANSFORMATIONS, supra note 3; MARK E. BRANDON, FREE IN THE WORLD: AMERICAN SLAVERY AND CONSTITUTIONAL FAILURE (1998); SUSAN R. BURGESS, CONTEST FOR CONSTITUTIONAL AUTHORITY: THE ABORTION AND WAR POWERS DEBATES (1992); BURT, supra note 2; DEVINS, supra note 2; LoUIS FISHER, CONSTITUTIONAL Dialogues: INTERPRETATION AS POLITICAL PROCESS (1988); Louis Fisher, CONSTITUTIONAL CONFLiCTS Between Congress and the President (3d ed. 1991) thereinafter Fisher, Constitutional Conflicts]; Kramer, The People Themselves, supra note 1; Powell, supra note 105; Keith Whittington, Constitution Construction: Divided Powers and Constitutional Meaning (1999). Further examples are cited in Whittington, supra note 1, at 847 n.350.

${ }^{108}$ It should be emphasized, here, that convergence as to the physical boundaries of the U.S. states and territories-those parts of the globe primarily governed by U.S. law rather than foreign lawdoesn't entail convergence as to how U.S. law governs. For example, the extent to which the Constitution constrains legislation vis-à-vis the territories has been a hotly debated issue in U.S. history. See, e.g., 8 OWen M. Fiss, The Oliver Wendell holmes Devise History of THE Supreme Court of 
their generally convergent recognition of certain institutions, such as the presidency and the Supreme Court, and the identity of the persons holding institutional roles; and their generally convergent validation of certain canonical nonconstitutional legal texts, such as the U.S. Code or the U.S. Reports-but they can and do significantly diverge.

To be sure, it is implausible that social facts about any odd collection of persons (blue-eyed Americans over fifty-five) will define a distinct body of U.S. constitutional law. The collection will need to satisfy some test of collective agency or the like, establishing its bona fides as a group. Further, the body of law that the group recognizes may perhaps need to be sufficiently well reflected in the actual activities of nongroup members as well as the group itself. But these constraints are too loose, conceptually, and in actual U.S. practice have been too loose, empirically, to identify a single grouping of Americans as the unique, recognitional community for the U.S.

The next two Parts of the Article defend a group-relative account of constitutional law. I have already outlined the overall structure of those two Parts, but because the argument is long and dense I will repeat the road map here. This Part argues that the social facts determinative of law (be they Lewis-conventions, SCAs, "constitutive" rules, or something else) can be instantiated by multiple groups located within the same territory and focused on the same constitutional text, and in U.S. practice have been. These groups can include groups of judges, groups of nonjudicial officials, and also groups of citizens. In this sense, both the positivist claim that the recognitional community consists of officials or judges, and the Dworkinian view that it consists of citizens, are partly vindicated-but only partly, of course, since the assumption shared by Dworkin and most positivists that a single recognitional community takes priority in determining legal content is what I am denying.

Part III argues that the putative bodies of law validated by the practices of different groups can have genuine explanatory and normative import and thus (at least in that sense) can be genuinely law. Dworkin and Hart end up identifying different canonical groups because their jurisprudential aims are different: Dworkin's is normative, while Hart's is descriptive or explanatory. ${ }^{109}$ Similarly, discourse about the U.S. Constitution might be normative (to assert what ought to be done) or explanatory (to understand or predict the behavior of various sorts of actors). The group-relative view of U.S. constitutional law is consistent, I will suggest, with both sorts of legal discourse.

Two final clarifying points. First, it should be noted that the grouprelative account does not presuppose general agreement on the legal roles that various persons occupy: on whether a person is a "citizen," an "offi-

THE UNITEd STATES: TROUBlEd BEgINNINGS OF THE MOdERN STATE, 1888-1910, at 225-56 (1993) (describing the Insular Cases).

109 See infra text accompanying notes 200-201. 
cial," a "judge," and so forth. Any account that posits a single, canonical recognitional community for U.S. law, and uses a legal category to define that community, faces the problem that different conceptions of the U.S. Constitution might define the membership of the legal category in different ways. This is a problem that my account avoids. In actual U.S. experience, as just mentioned, there has been broad consensus about what basic legal institutions exist ("Congress," "Supreme Court," "President") and what legal role a given natural person has-at least since the Civil War. I will therefore discuss the way in which the practices of "judges," "officials," and "citizens," or subsets of these groups, have grounded systems of U.S. constitutional law. But this convergence on institutions and on the legal role of particular natural persons within these institutions is a contingent rather than necessary feature of legal systems, according to the grouprelative account. ${ }^{110}$ The poignant pre-Civil War debate about whether the category of "citizen" included African Americans, punctuated by the Dred Scott decision, underscores the possibility of disagreement about legal identity and institutions, indeed about the very membership of the U.S. political community ${ }^{11}$ - a possibility that creates difficulties for the canonical accounts of law, not the group-relative account.

Second, a point about the individuation of legal systems. Individuation might be fine grained or coarse grained. A particular "system" of U.S. constitutional law might be the set of constitutional propositions validated by the practice of a particular group. If systems are individuated this finely, then of course there is a canonical group for each system-namely the group whose practices define it. By saying that there is no single recognitional community for U.S. law, I am (in effect) using a more coarse-grained, and more familiar, approach to individuation. The system of U.S. law is that system based in the text of the Constitution, commonly referred to using terms like "U.S. law," and possessing primary jurisdiction within a certain territory commonly acknowledged to be the United States. My claim is that there is no canonical recognitional group for this coarse-grained system-or, to put the point more accurately, that this coarse-grained system is really a plurality of fine-grained systems, each constituted by the practices of different recognitional groups.

${ }^{110}$ As discussed below, see infra text accompanying notes 178-182, it may be true that a large degree of institutional convergence is, in practice, required for the stability of a coarse-grained legal system, but that is different from stipulating that, conceptually, any coarse-grained system requires substantial or full institutional convergence of the constituent fine-grained systems for those to be legal systems. The group-relative account makes no such stipulation. On what I mean by "coarse-grained" and "fine-grained" legal systems, see the text immediately below.

111 See Wayne D. MOORE, CONSTITUTIONAL Rights AND POWERS OF THE PEOPLE 13-65 (1996) (describing this debate); Whittington, supra note 1, at 785 (noting that "[a]lthough the Taney Court may have denied the citizenship of Dred Scott for purposes of jurisdiction in a federal lawsuit, the Lincoln administration felt free to ignore the Court's opinion in order to recognize black citizenship in the context of the regulation of coastal ships, passports and patents"). 


\section{A. Recognitional Communities as Shared Cooperative Activities}

What particular kind of social fact grounds law? Hart, as we have seen, identifies the rule of recognition as a Lewis-convention: a rule that each member of a group follows because the others do. The current trend among positivists is to reject the view that the rule of recognition is a Lewis-convention. The key problem is that it makes each individual's acceptance of the rule of recognition merely a matter of general acceptance, and yet in many legal systems there appears to be a more robust acceptance of what is taken to be the fundamental law. As Shapiro puts it:

[M]ost Americans would [not] view the United States Constitution as an arbitrary solution to a recurring collective action problem. My guess is that many would believe that they had a moral obligation to heed a text that had been ratified by the representatives of the people of the United States, regardless of what everyone else did. Many officials would probably also share such an attitude. If most officials suddenly abandoned the United States Constitution, this would not lead all others to similar action. Some would resign in protest, while others would continue applying the rules validly enacted under the United States Constitution. ${ }^{112}$

Coleman, Shapiro, and Kutz all look instead to Michael Bratman's notion of a shared cooperative activity ("SCA"). There is a large philosophical literature on the problem of collective action and intention. How should talk about the activities, beliefs, etc. of plural subjects be understood? ${ }^{113}$ What does it mean to say, for example, that we cooked dinner together, or went for a walk together, or painted a house together? Something more, surely, than that you cooked dinner and I cooked dinner at the same time; or that you went walking along one route and I happened to walk in the same place; or that you painted a house and I the same house. Bratman, in a well-known and influential analysis, reduces genuine collective action to a structured set of individual actions and intentions-to an SCA, which involves the three conditions of "mutual responsiveness," "commitment to the joint activity," and "commitment to mutual support."

Mutual Responsiveness.-In SCA each participating agent attempts to be responsive to the intentions and actions of the other, knowing that the other is attempting to be similarly responsive. Each seeks to guide his behavior with an eye to the behavior of the other, knowing that the other seeks to do likewise.

112 Shapiro, supra note 68 , at 393 . For similar objections, see COLEMAN, supra note 50, at 94-95; Kutz, supra note 57, at 454-55; Marmor, supra note 70, at 517-18.

113 Important contributions to, or overviews of, this literature include: MICHAEL BRATMAN, FACES OF INTENTION 93-161 (1999); 2 CONTEMPORARY ACTION THEORY: SOCIAL ACTION (Ghita Holmstrom-Hintikka \& Raimo Tuomela eds., 1997); MARGARET GILBERT, ON SOCIAL FACTS (1989); Seumas Miller, Social action: A Teleological account (2001); John R. SEarle, The CONSTRUCTION OF SOCIAL REALITY (1995); SOCIAL FACTS AND COLlECTIVE INTENTIONALITY (Geotg Meggle ed., 2002); Socializing Metaphysics: THE Nature of Social Reality (Frederick F. Schmitt ed., 2003). 
Commitment to the Joint Activity.-In SCA the participants each have an appropriate commitment (though perhaps for different reasons) to the joint activity, and their mutual responsiveness is in the pursuit of this commitment.

Commitment to Mutual Support.-In SCA each agent is committed to supporting the efforts of the other to play her role in the joint activity. If I believe that you need my help to find your note (or your paint brush), I am prepared to provide such help; and you are similarly prepared to support me in my role. These commitments to support each other put us in a position to perform the joint activity successfully even if we need help in certain ways. ${ }^{114}$

Coleman, Shapiro, and Kutz draw on Bratman's notion of an SCA, albeit in somewhat different ways. Coleman now sees the rule of recognition as a straight SCA. ${ }^{15}$ Shapiro drops the third condition, commitment to mutual support, arguing that a legal system can exist if officials are genuinely responsive to each other and committed to the task of crafting criteria of legal validity, but merely profess a commitment to mutual support without actually intending to provide such support. ${ }^{116}$ Kutz offers a yet weaker view, in effect emphasizing Bratman's second condition and dropping both the first and third conditions. ${ }^{117}$

Interestingly, the antipositivist Dworkin also sees law as resting on something like an SCA. Dworkin, remember, writes in Law's Empire that the practices of a community that satisfies certain additional conditions (its members share a sense that they have special responsibilities to each other, a sense that these flow from a more general obligation of concern for each other's well-being, and a belief in equal status) can give rise to genuine associative, moral obligations. But what, exactly, does Dworkin mean by "community"? A subsequent article, Liberal Community, suggests that a Dworkinian community is not very different from an SCA. He uses the orchestra as a paradigm of community and explains:

First, collective agency presupposes acts socially denominated as collective, that is, acts identified and individuated as those of a community as a whole .... Second, the individual acts that constitute collective acts are concerted. They are performed self-consciously, as contributing to the collective act, rather than as isolated acts that happen to coincide in some way. The orchestra performs a particular concerto only when its members play with a cooperative intention; it would not perform at all if its musicians played exactly the same notes assigned to them in the score, at exactly the designated moments, and in the same room, but with no intention of playing together as an

\footnotetext{
114 BRATMAN, supra note 113, at 94-95.

115 See CoLEMAN, supra note 50, at 96-100.

116 See Shapiro, supra note 68, at 426-32.

117 See Kutz, supra note 57, at 455-60.
} 
orchestra. Third, the composition of the community ... is tailored to its collective acts .... 118

In this Part, I will show that the SCA-based account of law supports a group-relative account, in that SCAs are multiply realizable within a single coarse-grained legal system. I will develop this argument-with reference to U.S. constitutional history-by focusing on Scott Shapiro's work, the most fully developed jurisprudential work on SCAs. I will generally use the term "proto-SCA" in discussing Shapiro's account because, as mentioned, that account omits the mutual support component of a full-blown SCA.

Shapiro argues that, in any legal system, officials as a group are engaged in the proto-SCA of "creating [and] maintaining a unified system of rules." 19 This is the activity that the officials are plurally engaged in, just like "painting the house" or "taking a walk" is the collective activity that we perform when you and I intend, with common knowledge, to paint a house or take a walk together and to do so in a mutually responsive way, and act on these intentions. According to Shapiro, each official (1) intends that she and the other officials together create and maintain a unified system of rules (joint commitment, Bratman's second condition), and (2) intends that her particular conception of the criterion of validity for the rules "mesh" with the conceptions held by other officials (mutual responsiveness, Bratman's first condition), and further all of this is common knowledge among the officials (since, as Bratman explains, the various intentions constitutive of SCAs only become shared intentions when the agents holding them become mutually aware that they do so). ${ }^{120}$ Each official intends to apply the same tests for legal validity as the other officials and to do so responsively, that is, to resolve differences with the others about the appropriate tests for validity through bargaining, deliberation, or a resort to authority, and these intentions are mutually transparent. ${ }^{121}$

Shapiro assumes that U.S. officials as a whole are engaged in the proto-SCA of formulating a unified system of legal rules based on the U.S. Constitution. But whether officials as a whole are thus engaged is a contingent, empirical matter. It is quite possible-I want to claim - to have multiple groups of officials simultaneously instantiating separate proto-SCAs, such that officials in each group are engaged in a proto-SCA with each

118 Ronald Dworkin, Liberal Community, 77 CAL. L. REV. 479, 495 (1989). But see Ronald Dworkin, Thirty Years On, 115 HARV. L. REV. 1655, 1663 (2002) (criticizing Coleman's SCA-based account of law and noting "it is hardly a conceptual necessity that the actors in the legal processes of any country display the mix of attitudes ... defining an SCA").

119 Shapiro, supra note 68, at 426.

120 Strictly speaking, Shapiro requires "public accessibility," which is a weaker version of Bratman's common-knowledge requirement. See id. at 412,429 . That point of difference with Bratman does not figure at all in my analysis and thus, to avoid additional complexity, I will refer to Shapiro's condition using the term "common knowledge."

121 See id. at $417-32$. 
other but not with officials in the other group. Persons in each group might, with common knowledge, have the intention to work together, responsively, with persons in that group to develop a common criterion of legal validity grounded on the U.S. Constitution (thus each group realizes a proto-SCA internally), but one or more of the conditions for linking the two groups in a larger proto-SCA might fail. Members of one group might not see themselves as working together with the other group in developing constitutional law (and derivatively, U.S. law); or, they might thus see themselves but, on some range of matters, not be committed to "meshing" their conception of constitutional law with the other group's conception; or the common knowledge condition might fail.

Indeed, over the course of U.S. history, different groups of officials have often held different conceptions of constitutional law. In particular, there have been at least four salient divisions among officials on constitutional matters: four ways in which the overall collectivity of officials has repeatedly divided itself into smaller groupings holding divergent constitutional views and, perhaps, comprising separate proto-SCAs. The first division is departmental, involving the three branches of the national government: the President, the Congress, and the Supreme Court. The Justices of the Supreme Court, of course, advance their conceptions of constitutional law, announced in the U.S. Reports, in the course of adjudicating cases; but members of Congress and the President also articulate and act on constitutional views. Representatives and Senators do so in the course of considering legislation, constitutional amendments or appointments (for example, judicial appointments) and, more seldom, impeachments, or in the information gathering that is preparatory to legislation (witness constitutional struggles with the President over executive privilege). ${ }^{122}$ Presidential views of constitutional law come into play in a host of contexts: proposing, enacting or vetoing legislation; appointments and removals; pardons; formal executive orders to agencies, or less formal interventions, to shape agency regulations that implicate constitutional issues that the President cares about; prosecutorial and enforcement decisions by the Attorney General or other presidential appointees; the use of force abroad (witness struggles with Congress over the War Powers Act); and others. ${ }^{123}$

Given partisan divisions within Congress, it is questionable whether Congress as a whole fits the model of a proto-SCA. A presidential admini-

122 See DEVINS, supra note 2, at 25-33; see also FiSHER, CONSTITUTIONAL CONFLICTS, supra note 107 (generally documenting constitutional decisionmaking by Congress as well as the President); WHITTINGTON, supra note 107 (same); Symposium, Elected Branch Influences in Constitutional Decisionmaking, 56 LAW \& CONTEMP. PROBS. 1 (1993) (same). Two excellent books about constitutional decisionmaking by nonjudicial officials were published subsequent to the drafting of this Article. They are Neal DeVINS \& Louis Fisher, THE DEMOCRATIC CONSTITUTION (2004), and J. MitChell PiCKERILL, CONSTITUTIONAL DELIBERATION IN CONGRESS: THE IMPACT OF JUDICIAL REVIEW IN A SEPARATED SYSTEM (2004).

${ }^{123}$ See DEVINS, supra note 2, at 33-38; Easterbrook, supra note 2, at 906-16. 
stration does so much more plausibly. "Administration" is a fuzzy term, encompassing the President himself and whoever else is committed to carrying out the President's agenda: staffers in the White House as well as presidential appointees or even civil servants within the Executive Office of the President or the agencies, who view themselves as agents for the President, working to advance his political goals. ${ }^{124}$ Particular office-holders, depending on their orientation, belong to the Administration only intermittently-for example, some Attorneys General have seen themselves as presidential partisans, while others have adopted a more impartial conception of their role ${ }^{125}$ - but each President brings with him some officials who intend to work together to advance his agenda.

Add common knowledge and mutual responsiveness and we have a proto-SCA. Add constitutional elements to the President's agenda, and the presidential Administration then has its partial object applying a particular kind of criterion of legal validity, namely one incorporating the President's views about the Constitution. Assume, now, that the conception of constitutional law pressed by the Administration diverges from Supreme Court doctrine. This last assumption is hardly unrealistic: Presidents have repeatedly challenged the Court on constitutional matters. "[T]he presidency is perhaps the most significant competitor with the Court for constitutional authority."126 Thomas Jefferson, Andrew Jackson, Abraham Lincoln, Franklin Roosevelt and Ronald Reagan are the clearest (but not the only) examples. ${ }^{127}$ For example, Reagan's opposition to Roe $v$. Wade prompted a systematic effort by his Administration to cut back on abortion rights. "The Reagan White House not only used judicial appointments but also made vigorous use of appointments to executive posts to pursue its regulatory campaign against abortion"; ${ }^{28}$ it unsuccessfully proposed anti-abortion statutes; more successfully, the Administration spearheaded a host of regulatory measures limiting abortion rights; and the Office of Solicitor General under Reagan took an anti-Roe line in its amicus filings with the Supreme Court, nearly succeeding in prompting the Court to overrule Roe in the Webster case. ${ }^{129}$

124 Cf. B. Dan WOOD \& Richard Waterman, Bureaucratic DyNamics: The Role of BUREAUCRACY IN A DEMOCRACY 27-127 (1994) (examining responsiveness of federal agencies to the President as well as other actors).

125 See Nelson Lund, Rational Choice at the Office of Legal Counsel, 15 CARDOZO L. REv. 437 (1993); John O. McGinnis, Models of the Opinion Function of the Attorney General: A Normative, Descriptive, and Historical Prolegomenon, 15 CARDOZO L. REV. 375 (1993).

126 Keith E. Whittington, The Political Foundations of Judicial Supremacy, in CONSTITUTIONAL Politics: Essays on CONSTItution MAKING, MaINTENANCE AND ChANGE 261, 264 (Sotirios A. Barber \& Robert P. George eds., 2001).

127 See, e.g., Paulsen, supra note 2, at 255-62, 272-84; Whittington, supra note 126, at 270-75; Keith Whittington, Presidential Challenges to Judicial Supremacy and the Politics of Constitutional Meaning, 33 POLITY 365 (2001).

128 DEVINS, supra note 2, at 107.

129 See id. at $97-120$. 
The Reagan Administration, then, was plausibly a proto-SCA with the object of developing and maintaining a system of U.S. law consonant with Reagan's belief that women had no constitutional right to abortion. Did the participants in this proto-SCA necessarily include, not merely the officials in the Administration, but also members of the Supreme Court: in particular, the Justices who believed that Roe was correctly decided? First, members of the Administration may not have satisfied Bratman's "joint commitment" condition vis-à-vis the pro-Roe Justices or the Justices more generally. If officials within a presidential administration take as their object applying a particular kind of criteria of legal validity, namely criteria that the President has endorsed or would endorse, while the Justices aren't committed to employing validity criteria that mirror the President's constitutional and legal views (and let's hope they aren't), then it doesn't seem that the officials and the Justices intend to engage in the same activity. Joint commitment as between members of the President's Administration and the Justices would seem to fail, not only in the case of Reagan's antiabortion struggles but much more generally.

And even if joint commitment doesn't generally fail, and didn't fail in that particular case, presumably the members of the Reagan Administration did not satisfy Bratman's mutual responsiveness condition vis-à-vis the proRoe Justices. Officials developing a system of rules intend to be mutually responsive, again, if they all intend that their particular conceptions of legal validity be harmonized or "meshed" where these diverge. But, presumably, the Reagan Administration had no intention of harmonizing its anti-Roe stance with the views of the pro-Roe Justices. Rather, the Administration's intention (plausibly) was to implement a constitutional conception that denied abortion rights and to circumvent the pro-Roe Justices, who held a conflicting view, as far as possible.

To be sure, in circumventing the pro-Roe Justices, the Administration would need to (1) honor whatever constitutional powers the Administration's own constitutional conception accorded those Justices (for example, the power to issue binding judgments in particular cases, a power the Administration didn't deny), and (2) take account, strategically, of the fact that the Justices and others supported Roe. But neither the first nor the second kind of responsiveness is the same as a full-fledged commitment on the part of the Reagan Administration to "mesh" with the pro-Roe Justices' divergent conception of constitutional law. If $P$ 's and $Q$ 's conceptions concur that $Q$ has some legal role, but disagree in other ways, and if $P$ intends to take account of $Q$ 's views in the zone of disagreement only if it is strategically useful for $P$ to do so- only where $P$ can better implement his own conception by taking account of $Q$ 's views-then $P$ is not (I take it) committed to "meshing" his conception with $Q$. Consider the following example of a failure of mutual responsiveness, which Bratman provides. 
[S]uppose that you and I each intend that we paint the house together, our subplans happen so far to mesh, but neither of us is committed to maintaining this mesh. Suppose our subplans happen to agree on red. We may still ask how I would be disposed to act if you were unexpectedly to announce a preference for blue. In the absence of a commitment to mesh I would tend to be willing to bypass (rather than seek a mesh with) your subplans, so long as we still thereby paint the house together. For example, I might try to pour red paint into your paint can when you are not looking. And this would signal the absence of a cooperative attitude characteristic of SCA. ${ }^{130}$

My point is that the Reagan Administration might have had just this sort of "uncooperative" attitude vis-à-vis the pro-Roe Justices.

The case of Reagan's abortion agenda shows how the members of an administration might comprise a proto-SCA which does not encompass some members of the Supreme Court (in this case, those Justices who supported abortion rights). We still haven't shown multiple simultaneous proto-SCAs, but that seems straightforward. Presumably the pro-Roe Justices were part of some proto-SCA: one encompassing the entire Supreme Court, or the entire federal judiciary, or the entire judiciary, or perhaps a subset of judges, federal judges, or Supreme Court Justices, e.g., judges sharing a certain constitutional jurisprudence.

Although Reagan made intense and visible efforts to limit abortion rights, his disagreement with the Court was localized, focusing on one area of doctrine. Roosevelt's campaign against the Court, culminating in the court-packing plan, was yet more intense, and his differences with the Justices were much larger, involving very general constitutional questions about the scope of federal legislative power, Lochner, and the legitimacy of the administrative state. ${ }^{131}$ I have focused on Reagan, not Roosevelt, both because Reagan is more recent and because the Reagan example shows that even a localized disagreement between the President and the Court can vitiate their collective agency, where the President and his Administration are firmly committed on some constitutional issue and have no intention of "meshing" their views with the Court (thus vitiating mutual responsiveness). But, lest the Reagan example fail to persuade the reader that the presidential Administration and the Court (or some set of Justices) can embody separate and simultaneous proto-SCAs, the Roosevelt example should. Roosevelt saw the Justices, or at least the conservative bloc (the "Four Horsemen"), as deeply misguided figures who had obstructed much of his legislative program and whose influence on constitutional doctrine needed to be minimized, if necessary through a court-packing scheme that would dilute their votes. ${ }^{132}$ The suggestion that Roosevelt nonetheless satisfied the joint commitment condition vis-à-vis the Four Horsemen, let alone

130 BRATMAN, supra note 113 , at 99.

131 See, e.g., 2 ACKERMAN, TRANSFORMATIONS, supra note 3, at 279-311.

132 See Whittington, supra note 127 , at 380-82. 
the mutual responsiveness condition - that Roosevelt intended that the Justices play some active ${ }^{133}$ role in maintaining the U.S. legal system-is ludicrous.

I see no limit, in principle, to the ways in which the body of U.S. officials might be divided up into multiple proto-SCAs, but, as I said earlier, in practice there have been (at least) four salient fault lines, each leading repeatedly to constitutional disagreement among different groups of officials. The first, again, is departmental (the President, the Supreme Court, the Congress). The second is partisan, involving political party affiliation-in our time, affiliation with the Republican and Democratic parties. The two major modern parties, like their nineteenth-century predecessors, have played an active role in developing criteria of legal validity for U.S. law, not just at the level of statutory law (which validates regulatory and other substatutory law), but at the level of the Constitution itself. The parties themselves, in their official platforms, as well as party leaders and activists, frequently take positions on constitutional matters. ${ }^{134}$

I do not suggest that the overall body of officials in each party constitutes, or has ever constituted, a proto-SCA. The collective agency of each of these bodies might well be vitiated by departmental, regional, statefederal, or other internal divisions. Rather, the thought is that proto-SCAs could emerge from various subsets of each party's membership. Consider, as a paradigm, the members of the Democratic caucus in the Congress, and the members of the Republican caucus in the Congress. The Democratic members, or at least the party loyalists among them, could well intend to work, responsively, together (through legislation and appointments and perhaps more extreme measures, such as impeachments, jurisdictionstripping, or constitutional amendments) to develop constitutional law as well as ordinary statutory law; and the Republican members, or at least the party loyalists, could have an isomorphic, competitive, collective intention. ${ }^{135}$

133 See infra text accompanying note 136 (discussing Bratman's stipulation that the members of an $\mathrm{SCA}$ intend each other to be actively involved in advancing the joint project).

134 See 1 THE ENCYCLOPEDIA OF THE REPUBLICAN PARTY 67-70, 70-72, 126-27, 127-28, 172-74, 177-78, 182-84 (George Thomas Kurian ed., 1997) (summarizing positions of Republican party factions or party as a whole on abortion, affirmative action, freedom of speech, gun control, religion, school prayer, and states' rights); 3 THE ENCYCLOPEDIA OF THE DEMOCRATIC PARTY 67-69, 69-72, 127-28, 128-29, 172-75, 175-76, 180-83 (George Thomas Kurian ed., 1997) (same for Democratic party).

135 One need not have an inflated view of party discipline and the party's role in modern American politics to think that contemporary parties or party factions might adopt constitutional positions which party or faction members seek to advance. See JohN H. Aldrich, WhY PARTIES? THE ORIGIN AND TRANSFORMATION OF POLITICAL PARTIES IN AMERICA 18-61 (1995) (conceptualizing the modem American party as an institutionalized coalition of office-seekers and office-holders that advances their electoral and policy preferences in various ways-for example by providing a "brand name" that cheaply informs voters about candidates); see also KRAMER, THE PEOPLE THEMSELVES, supra note 1, at 189-203 (discussing Van Buren's view of the Democratic party as a locus of popular constitutionalism). 
The thought that Democratic Congressmen somehow must satisfy Bratman's joint commitment and mutual responsiveness conditions, vis-àvis Republican Congressmen, and vice versa, either weakens those conditions to the point where they mean nothing more than the strategic interaction of legislators whose clashing plans recognize some role for each other, or underestimates partisanship. Consider, for example, the partisan Republican in a Congress with a Republican majority, who believes with most of her fellow Republicans that a proposed statute would be constitutional while most of the Democrats believe it would not be. This Republican legislator intends to act on her own constitutional view and to handle the Democrats' conflicting view, not by coaxing or persuading the Democrats to change their view or, alternatively, by changing her own, but simply by ignoring the Democrats' constitutional concerns and voting in favor of the statute together with her fellow Republicans. She intends to circumvent the Democrats - an option that the majoritarian voting rules of Congress afford a majority party-rather than to harmonize the two parties' constitutional differences. So this legislator does not satisfy the mutual responsiveness condition vis-à-vis the Democrats, and she may not satisfy the joint commitment condition either. Bratman stresses that joint commitment involves an intention on the part of the individual members of the joint project that they all play an active role in that project. For example, if $I$ intend that we go to New York in such a way that you are entirely passive (specifically, I intend to tie you up and drive you to New York) then joint commitment fails. ${ }^{136}$ The Republican legislator in a Congress with a Republican majority (and quorum) might hope that the Democrats simply absent themselves from the legislature, rather than intending that they play an active part in shaping U.S. law.

The departmental and partisan fault lines regularly lead to constitutional disagreements among officials-disagreements that, I have tried to show, could be embedded in multiple proto-SCAs. Two other recurrent fault lines are regional and state-federal. In particular, Northern officials (both federal and state) have regularly clashed with Southern officials on deep constitutional questions: the constitutional status of slavery in the preCivil War period ${ }^{137}$ and the constitutional status of Jim Crow in the aftermath of Brown v. Board of Education. ${ }^{138}$ And state officials have, at least sometimes, advanced a distinctive view, not just of wise policy (embodied in state law), but of federal constitutional law. Consider the antifederalist views advanced by the Kentucky and Virginia legislatures in their 1798 and 1799 resolutions opposing the federal Alien and Sedition Acts; ${ }^{139}$ by the

136 See BRATMAN, supra note 113 , at 100.

137 See BRANDON, supra note 107 , at 116-38.

138 See, e.g., MichaEl J. Klarman, From Jim Crow to Civil Rights: The SuPreme Court AND THE STRUGGLE FOR RACIAL EQUALITY 332, 348-49, 364-66 (2004).

139 See MOORE, supra note 111, at 239-62. 
Virginia Court of Appeals in its dispute with the U.S. Supreme Court in Martin v. Hunter's Lessee, concerning the Supreme Court's appellate jurisdiction over state supreme courts; ${ }^{140}$ by Georgia courts and executive officials in challenging the Supreme Court's authority, asserted in Worcester $v$. Georgia, to resolve issues of state versus Indian tribal sovereignty; ${ }^{141}$ and by the South Carolina legislature in its purported nullification of the federal tariffs of 1828 and 1832. ${ }^{142}$ Each of these latter two fault lines, alone or in combination with others, has (quite plausibly) given rise to competing groups that have different constitutional conceptions and have sufficient internal bonds to be proto-SCAs.

Let me emphasize: I do not claim that groups of officials defined by departmental, partisan, regional, or state-federal affiliation, or by some intersection of these categories, now or always comprise proto-SCAs. Whether a proto-SCA arises among some group of officials is an empirical question, dependent on the actual attitudes and behaviors of the officials. My claim, rather, is that the attitudes constitutive of proto-SCAs could, in principle, be held simultaneously by multiple groups of officials, and that some such pattern plausibly has arisen at various points in U.S. history. If the proto-SCA is indeed the distinctive "social fact" constitutive of law, then nothing in the nature of that social fact precludes its instantiation in multiple, simultaneous official groupings.

One worry here is that the officials in my examples recognize each other as officials: Republican members of Congress recognize their partisan competitors across the aisle as Congressmen, the anti-abortion President recognizes the pro-abortion Justices as Justices, and so on. But mutual recognition as officials doesn't imply identity of constitutional conception. Two persons can espouse constitutional conceptions that coincide in the offices ascribed to the two persons (each conception sees one of the two as "President" and the other as "Justice"), but diverge in other ways. Another worry is that a person holding a constitutional conception ascribing an office to another person necessarily satisfies Bratman's joint commitment condition. The first person necessarily recognizes, by this ascription, that the second has some legal power. For example, even Roosevelt recognized that the Four Horsemen had the power to cast a vote on Supreme Court cases, and even partisan Republicans in Congress recognize that their De-

140 See Richard H. Fallon et al., HaRt AND Wechsler's the Federal Courts and the FEDERAL SYSTEM 495-507 (4th ed. 1996); see also Charles Warren, Legislative and Judicial Attacks on the Supreme Court of the United States-A History of the Twenty-Fifth Section of the Judiciary Act, Part I, 47 AM. L. REV. 1, 3-4 (1913) ("Between 1789 and 1860 the courts of seven States denied the constitutional right of the United States Supreme Court to decide cases on writs of error to State courtsVirginia, Ohio, Georgia, Kentucky, South Carolina, California and Wisconsin. The Legislatures of all these states (except California), and also of Pennsylvania and Maryland, formally adopted resolutions or statutes against this power of the Supreme Court.").

141 See KRAMER, THE PEOPLE THEMSELVES, supra note 1, at 182.

142 See id. at $178-82$. 
mocratic counterparts have the power, with their votes, to enact or defeat legislation. But, as these examples tried to suggest, a person might recognize that some other fills a legal office yet not intend that the other exercise the powers of that office-indeed hope that she remain passive-thus vitiating joint commitment. In any event, mutual responsiveness is a separate condition of proto-SCAs, additional to joint commitment. By holding a constitutional conception that ascribes you official status, I surely need not intend to mesh my conception with yours where they diverge-for my conception might also afford me opportunities for circumvention. If I give you a paintbrush and keep one for myself, hoping that you'll paint the house red and intending to paint over any other color that you might paint, then my intentions are not yet sufficiently cooperative to create a proto-SCA. The same can occur with constitutional intentions.

On this score, a final, significant worry: namely that the special place of the Supreme Court in standard constitutional conceptions does entail responsiveness to the Court, thereby vitiating departmental as well as nondepartmental divisions on constitutional matters. Imagine a Republican and Democratic legislator, each endorsing the Cooper $v$. Aaron principle that a Supreme Court ruling on constitutional matters binds the world, not just the parties to the case. Then it might be thought that each legislator (1) intends to mesh his constitutional views with the Court, namely by adopting the Court's views, and (2) intends or at least expects to mesh his views with the other legislator, since once the Court's views on some matter are announced, any difference between the legislators on that matter will dissolve (given their commitment to Cooper). But in fact nonjudicial actors who accept Cooper don't necessarily satisfy mutual responsiveness vis-à-vis each other, since they might not intend or expect to mesh with each other in those areas of constitutional law where the Court seldom rules, such as war powers and foreign affairs, ${ }^{143}$ or (by virtue of its deferential doctrines) fails to reach the merits of constitutional differences, such as "rational basis" cases under the Due Process and Equal Protection Clauses. ${ }^{144}$

In any event, nonjudicial officials can and have rejected the Cooper principle. Cooper was issued, remember, only in the aftermath of Brown. ${ }^{145}$ In prior constitutional practice, it seems, the principle was avowed by some judges, officials, and other legal actors but was publicly contested by others. ${ }^{146}$ Presidents Madison, Jefferson, Jackson, Lincoln, and Roosevelt all publicly denied an obligation to obey Supreme Court rulings per se, and

143 See Alexander M. Bickel, The least Dangerous Branch: The Supreme Court at the BAR OF POLITICS 111-98 (2d ed. 1962) (surveying Supreme Court's devices for avoiding constitutional questions); Barkow, supra note 16 (discussing scope of "political question" doctrine).

144 See sources cited supra note 14 (conceptualizing rational-basis tests as underenforcement mechanisms).

145 See Murphy, supra note 2, at 409-10.

146 See BURT, supra note 2, at 1-199; KRAMER, THE PEOPLE THEMSELVES, supra note 1, at 207-26. 
Reagan did so through his Attorney General Meese. ${ }^{147}$ Reagan is the only President since the Cooper decision whose Administration has publicly challenged its principle, ${ }^{148}$ but other Presidents may have rejected the principle more circumspectly. A President's strategic decision not to publicly disavow Cooper, given the political risks, is not the same as a genuine acceptance of the principle and concomitant intention to mesh his views with the Court's; rather, the President may intend to evade the Court's rulings quietly, where he can get away with it. ${ }^{149}$ Similarly, members of Congress these days tend not to criticize Cooper, but their practice (for example, the continuing enactment of legislative vetoes in the teeth of the Chadha decision) ${ }^{150}$ and survey research suggest that a substantial number of them don't accept it. ${ }^{151}$ So the notion of a nonjudicial official adopting a constitutional conception without Cooper's mesh-creating mechanism is hardly farfetched. ${ }^{152}$

What about citizens? Can groups that partly or wholly consist of nonofficial citizens comprise proto-SCAs? I suggest they can. To begin, throughout U.S. constitutional history citizen groups holding distinctive constitutional views have regularly emerged. This is one of the central contentions of Robert Cover's famous article, Nomos and Narrative. Cover writes: "Most of the literature concerning constitutional meaning has focused primarily on the work of courts and secondarily on that of other state officials. I shall start with the work of nonofficials and deal only in conclusion with the ways in which officials create or destroy meaning." 153 In particular, Cover describes two categories of citizen groups united (in part) by their special constitutional views: insular religious movements, such as the Amish and Mennonites, and activist groups "dedicated to radical transformations of constitutional meaning as it affects the application of state

147 See sources cited supra note 127. For Meese's speech criticizing judicial supremacy, see Edwin Meese III, The Law of the Constitution, 61 TUL. L. REV. 979 (1987).

148 See Kramer, The People Themselves, supra note 1, at 228.

149 See Whittington, supra note 1, at 799-800.

150 See INS v. Chadha, 462 U.S. 919 (1983); FISHER, CONSTITUTIONAL CONFLICTS, supra note 107, at 146-52; Louis Fisher, The Legislative Veto: Invalidated, It Survives, 56 LAW \& CONTEMP. PROBS. 273, 288-91 (1993).

${ }^{151}$ See Bruce G. Peabody, Congressional Constitutional Interpretation and the Courts: A Preliminary Inquiry into Legislative Attitudes, 29 LAW \& SOC. INQUIRY 127, 146-60 (2004).

152 My claim, in other words, is a possibility claim. Even if officials or citizens now generally do accept judicial supremacy, the fact of past public dissent (not just in the pre-Civil War period, but in the New Deal and post-New Deal periods, with Roosevelt and Reagan) illustrates that such general acceptance is a contingent feature of our constitutional experience. So the claim that officials or citizens will necessarily be committed to meshing their divergent constitutional views in virtue of their acceptance of Cooper must be rejected. As to current citizen views about judicial supremacy, see Barry Friedman, Mediated Popular Constitutionalism, 101 MicH. L. REV. 2596 (2003); Brian M. Feldman, Note, Evaluating Public Endorsement of the Weak and Strong Forms of Judicial Supremacy, 89 VA. L. REV. 979 (2003).

153 Robert M. Cover, Foreword: Nomos and Narrative, 97 HARV. L. REV. 4, 25 (1983). 
power," 154 such as the "radical" antislavery constitutionalists in the pre-Civil War period. The Amish and Mennonites followed a religious rule of recognition, a rule of obedience to God; since God's law, in turn, recognized civil authority, it validated the text of the Constitution, but demanded that the text be read (for example, through a broad reading of the Free Exercise Clause) to permit the insular, communal, observant way of life that these groups took to be integral to their religion. ${ }^{155}$ The antislavery constitutionalists understood the Constitution as an antislavery document; by means of creative readings of the rest of the text, they sought to undercut the apparent recognition of slavery in the three-fifths clause, the clause concerning the slave trade, and the Fugitive Slave Clause. ${ }^{156}$

While their movement lasted, the radical [antislavery] constitutionalists contributed to an immense growth of law. They worked out a constitutional attack on slavery from the general structure of the Constitution; they evolved a literalist attack from the language of the due process clause and from the jury and grand jury provisions of the fifth and sixth amendments; they studied interpretive methodologies and self-consciously employed the one most favorable to their ends; they developed arguments for extending the range of constitutional sources to include at least the Declaration of Independence. Their pamphlets, arguments, columns and books constitute an important part of the legal literature on slavery .... ${ }^{157}$

Let me generalize Cover's categories a bit: from insular religious communities to religious groups more generally, and from redemptive constitutionalists to public-interest groups. Citizens collected into churches or other religious organizations with their own constitutional views, or into secular groupings partly focused on some project of constitutional reform, are a familiar feature of U.S. political life. Consider, as examples of the first category, not merely the Amish and Mennonites but the Catholic Church and its anti-abortion stance, ${ }^{158}$ or the Christian Coalition and its support for school prayer. ${ }^{159}$ Consider, as examples of the second, not merely the antislavery constitutionalists but, more recently, the NAACP and its campaign against segregation; the ACLU and its campaign against sex discrimination; Planned Parenthood and abortion rights; Lambda and gay rights; ${ }^{160}$ or the NRA and Second Amendment rights. Further, churches and public interest groups are, intuitively, groups in a robust sense. Perhaps the

154 Id.

155 See id. at $26-33$.

156 See U.S. CONST. art. I, § 2, cl. 3; id. art. I, § 9, cl. 1; id. art. IV, § 2, cl. 3.

157 Cover, supra note 153, at 39; see also BRANDON, supra note 107, at 57-62 (describing antislavery constitutionalism).

158 See Lucinda Peach, Legislating Morality: Pluralism and Religious Identity in LAWMAKING 28-33 (2002).

159 See 1 THE ENCYCLOPEDIA OF THE REPUBLICAN PARTY, supra note 134, at 177.

160 See William N. Eskridge, Jr., Some Effects of Identity-Based Social Movements on Constitutional Law in the Twentieth Century, 100 MiCH. L. REV. 2062, 2072-2194 (2002). 
"civil rights movement" overall is too loose a grouping to constitute a plural subject, to license talk of collective agency and intention, but surely subsets of the persons within the "movement" can be collective agents, particularly when organized into formal groups like the ACLU and the NAACP. Ditto for religious groups: even if the "evangelical movement" is too diffuse to constitute a proto-SCA, surely the leadership group within a particular church is not.

So my suggestion is that groups of nonofficial citizens, paradigmatically religious groups or secular groups sharing some constitutional reform ideology, but not limited to such groups, might instantiate just the sort of proto-SCA Shapiro describes: the individuals belonging to the groups might, with common knowledge, intend to work together to maintain or realize some particular criterion of legal validity, and intend to harmonize any divergence in their constitutional views that might emerge. The main worry here-the main reason for thinking that the proto-SCAs grounding law must be limited to officials - is that the object of these proto-SCAs is (as Shapiro puts it) "creating [and] maintaining a unified system of rules." 161 How can citizens, either individually or collectively, do that? ${ }^{162}$ But of course citizens can actively work to effectuate their conceptions of constitutional law through a range of activities such as voting, litigating, lobbying, and political speechifying. Citizens can lobby legislators to repeal statutes they believe to be unconstitutional, vote out of office legislators who decline to do so, litigate to have these statutes invalidated, and implore other citizens to join their constitutional campaign. So the worry that the passive status of "citizen" precludes collective citizen activity targeted at legal rules is overblown. And, just as multiple groups of officials can instantiate different proto-SCAs characterized by divergent views about legal validity, so too can multiple groups of citizens.

What about the objection that a constitutional conception is not the same as a rule of recognition? Various groups, either official or citizen groups, might have divergent views about certain constitutional matters, such as the right of abortion or the scope of the Commerce Clause, but converge on a rule that they all take as axiomatic or foundational-for example, that the text of the Constitution is supreme federal law and properly interpreted in line with its plain meaning and, secondarily, the Framers' in-

161 Shapiro, supra note 68 , at 426 . A recent article by Doni Gewirtzman points to a different worry, namely that many citizens are currently apathetic about the Constitution. See Doni Gewirtzman, Glory Days: Popular Constitutionalism, Nostalgia, and the True Nature of Constitutional Culture, 93 GEO. L.J. 897, 913-14 (2005). Even if this is true, the upshot would only be that the citizenry in its entirety is not currently a proto-SCA. Widespread apathy is quite consistent with constitutional activism on the part of motivated subsets of the citizenry, as described in the text above. See also L.A. Powe, Jr., Are "the People" Missing in Action (and Should Anyone Care?), 83 TEX. L. REV. 855, 866-84 (2005) (describing a number of modern examples of citizen constitutional activism).

${ }^{162}$ See Shapiro, supra note 68, at 418 ("The business of law is the creation and exercise of authority, and its participants are the officials who operate the levers of legal power."). 
tentions. If Hart is correct that legal propositions are necessarily validated by derivation from a rule of recognition, ${ }^{163}$ then groups which converge at the rule-of-recognition level, but disagree about the truth of subsidiary legal propositions, constitutional or other, are actually instantiating the same (fine-grained) legal system. Imagine that two proto-SCAs accept the rule of recognition just stated. Then, on the Hartian view of legal validity, the proposition "it is unconstitutional to prohibit previability abortion" will either be true relative to both groups, or false relative to both groups, or indeterminate relative to both groups, depending on what "due process" means and what its Framers intended it to mean. This subsidiary, constitutional proposition can't have different group-relative truth-values, even though the two groups have different views about its truth, since the groups agree that the proposition is nonultimate, and agree as to what the ultimate rule is..$^{164}$

One response here is to challenge the Hartian view that legal propositions, other than those comprising the rule of recognition itself, are valid in virtue of derivation from that ultimate rule. ${ }^{165}$ Dworkin, for example, challenges Hart on this score. Legal validity, for Dworkin, turns on "interpretation" of the totality of legal propositions accepted by some group, ultimate and nonultimate propositions alike. ${ }^{166}$ A different challenge rests on the coordinative view of law's authority: only propositions that are actually accepted by a group, not propositions merely derivable from other group commitments, can have coordinative authority for group members, and so (at least insofar as "law" is adduced as a source of coordinative authority) two groups disagreeing about subsidiary legal propositions do represent different fine-grained legal systems. Similarly, a group might be epistemically authoritative for the subsidiary propositions it accepts, not merely for the subsidiary propositions derivable from the propositions it accepts as ultimate. ${ }^{167}$ Finally, turning from normative legal discourse to explanatory legal discourse, ${ }^{168}$ it would seem that group agreement on legal propositions seen as nonultimate could help explain group action and utterance even where those propositions aren't validated by whatever propositions the group accepts as ultimate.

In any event, even if Hart is correct about legal validity, it is certainly possible for different groups to accept different U.S. rules of recognition:

163 See Greenawalt, supra note 44, at 624-30 (discussing this aspect of Hart's account).

${ }^{164}$ See Himma, supra note 48, at $155 \mathrm{n} .11$ (noting a problematic case, for Hart, where "the officials mistakenly misidentify certain norms as being valid under the recognition norms they purport to accept").

165 See Greenawalt, supra note 44, at 661 (acknowledging the possibility that "the authoritative status of some norms ... depends both on oblique approval by higher norms and on acceptance").

166 See id. at 627; supra text accompanying notes 79-80.

167 See infra text accompanying notes 206-207 (discussing coordinative and epistemic authority).

168 See infra text accompanying note 191 (describing two variants of legal discourse, explanatory and normative). 
divergent views about the axioms from which the rest of U.S. law derives. ${ }^{169}$ In the pre-Civil War period, constitutional debate raged about whether the Constitution was a compact between states, the creation of a single national People, or something in between. That debate had large implications for the scope of federal legislative power, the supremacy of federal over state law, and the constitutional interpretive authority of federal versus state bodies. ${ }^{170}$ In the modern, post-New Deal period, there has been ongoing debate about which technique should be employed to interpret the text of the Constitution: originalism, a nonoriginalist textualism that incorporates a wide range of moral values, a nonoriginalist textualism that focuses on procedural values, and so on. ${ }^{71}$ And disputes about the interpretive supremacy of the U.S. Supreme Court have occurred throughout U.S. history. ${ }^{172}$ All of these matters are plausibly viewed as axiomatic or ultimate, ${ }^{173}$ and thus at least some of the groups on different sides of these debates surely accepted different rules of recognition in Hart's sense: they would have avowed different principles as foundational.

\section{B. "Constitutive" Rules, Lewis-Conventions, and Social Norms}

The cutting-edge view in jurisprudence seems to be that the social fact undergirding law is an SCA or some variation. I have thus tried to show at some length, with reference to U.S. constitutional history, that multiple groups-including citizen groups as well as official groups-can simultaneously instantiate separate proto-SCAs each with the aim of advancing its own conception of constitutional law. Thus, SCAs are consistent with a group-relative account of law. ${ }^{174}$ But what if we shift to other sorts of social facts: "constitutive" rules, Lewis-conventions, social norms?

Andrei Marmor, like Kutz, Shapiro, and Coleman, is critical of Hart's notion that the rule of recognition amounts to a Lewis-convention among officials. But Marmor proposes to replace Lewis-conventions with "constitutive" rules rather than SCAs. ${ }^{175}$ I take it that the difference between SCAs and "constitutive" rules (a construct developed by the philosopher John

169 See Greenawalt, supra note 44, at 661 (noting that different officials may "have variant notions of the point of ultimacy for the authority of some legal standards").

${ }^{170}$ See, e.g., BRANDON, supra note 107, at 46-52; MOORE, supra note 111, at 275-86. For modern echoes of this dispute, see U.S. Term Limits, Inc. v. Thornton, 514 U.S. 779 (1995).

171 See, e.g., RoBert H. BORK, THE TEMPTING OF AMERICA: THE POLITICAL SEDUCtion of the LAW (1990).

172 See supra text accompanying notes 145-152.

173 See Alexander \& Schauer, supra note 21, at 1370 (suggesting that the U.S. rule of recognition could speak to the allocation of interpretive authority); Greenawalt, supra note 44 , at $659-60$ (suggesting that the U.S. rule of recognition addresses the question of interpretive techniques).

${ }^{174}$ If it is true that proto-SCAs in Shapiro's sense can be simultaneously instantiated by multiple groups, then it is true a fortiori that full-blown SCAs can. Full-blown SCAs are proto-SCAs that satisfy an additional condition, namely mutual support. See supra text accompanying notes 113-118.

175 See Marmor, supra note 70, at 518-31. 
Searle) is twofold. First, Searle claims, collective intention is a primitive phenomenon that cannot be defined in terms of an interlocking set of individual intentions, ${ }^{176}$ as Bratman has attempted to do. Second-and more important for purposes of this Article-Searle emphasizes that social practice can create new entities: entities that wouldn't exist absent the practice.

On this latter score, consider the difference between Rob and Jane's collective intention to paint a rock and Americans' collective recognition that Ruth Bader Ginsburg is a Supreme Court Justice. I use the example of a group that intends to paint a rock, rather than Bratman's example of a group that intends to paint a house, because the rock example provides the clearest possible contrast with the Ginsburg case. Absent Rob and Jane's collective intention, the rock would still be there, and Rob and Jane could each paint it; but absent our collective recognition, Ruth Bader Ginsburg wouldn't be a Supreme Court Justice. Many features of social reality, nonlegal and legal alike, would not exist without collective recognition: money, marriage, cocktail parties, chess, the Statue of Liberty, Congress, the President, the U.S. Code, and so on. ${ }^{177}$

Marmor has not explained in detail how Searle's notion of "constitutive" rules should be employed to explicate a legal system, but I take it the account would go roughly as follows: a legal system rests upon the collective intentionality of a group of individuals, who collectively recognize certain entities (which exist only by virtue of their recognition) and collectively intend to do their part in creating and maintaining a system of rules. Yet multiple groups of persons, be they officials or citizens, can instantiate a Searlean collective intention to act together in developing a system of rules-specifically, a system of rules under the U.S. Constitution. There is nothing in the Searlean account to mandate a single canonical group, or to mandate an official rather than citizen group, any more than in Bratman's notion of an SCA.

In principle, I suppose, the collective intentionality of distinct Searlean groups might constitute distinctive entities. One group might recognize certain "courts" or "codes" or "legislatures" or "presidents" that the other

176 See SEARLE, supra note 113, at 23-26; John R. Searle, Collective Intentions and Actions, in INTENTIONS IN COMMUNICATION 401, 401 (Philip R. Cohen et al. eds., 1990). Searle agrees that collective intentionality depends on individual brain states. If $\mathrm{Jim}^{*}$ and June* have exactly the same brain states as Jim and June, respectively, then it can't be the case that Jim* and June* instantiate a collective intentionality that Jim and June lack. So collective intentionality (as per Searle) isn't some ghost in the machine. It's simply a form of mental life that can't be defined in terms of more familiar forms, namely ordinary, individual intentions and beliefs.

Margaret Gilbert, in her influential work on collective agency, makes a similar claim. See Frederick F. Schmitt, Socializing Metaphysics: An Introduction, in SOCIALIZING METAPHYSICS: THE NATURE OF SOCIAL REALITY, supra note 113, at 9-13 (describing Gilbert's account, with a particular focus on the fact that it doesn't reduce collective intentions to individual intentions).

177 See SEARLE, supra note 113, at 27-57; JOHN SEARLE, SPEECH ACTS: AN ESSAY IN THE PHILOSOPHY OF LANGUAGE 33-42 (1969). 
group declines to recognize. Imagine radical constitutionalists who read the Fourteenth Amendment to mandate "one person, one vote" at all levels of government, overriding Article I, and thus insist that there is no such thing as the Senate. ${ }^{178}$ In practice, as already noted, the divergent constitutional conceptions held by different groups of U.S. officials or citizens don't diverge that much. Why not? The answer may, in part, be the general importance of textualism in U.S. constitutional cultures. Much of the work done by the text of the Constitution is to create (strictly, attempt to create) new legal entities: "Congress," the "Supreme Court," the "President." So any group's criterion of legal validity for U.S. law will, if that criterion accords substantial weight to the text, draw many of the new entities that it recognizes from that text; and the various groups' criteria, although different, will largely converge in the entities they recognize. Call this "institutional convergence." Here I am using "institution" as a rough synonym for a socially constituted entity: ${ }^{179}$ an entity, such as "Congress" or "the Supreme Court," whose very existence depends on collective intentionality of some sort.

The fact of institutional convergence is an important feature of U.S. practice. It presumably helps explain our peace and prosperity. (Contrast the current state of institutional convergence with the Civil War years, where many recognized an institution, the Confederate States of America, that many others declined to recognize. $)^{180}$ It might even be suggested that any coarse-grained legal system-that is, any collection of groups with legal conceptions governing the same territory-cannot exist for long without a large degree of institutional convergence among these different conceptions. ${ }^{181}$ Absent such convergence, perhaps, there would soon be violence leading either to anarchy (no effective ${ }^{182}$ conceptions at all), or the disappearance of a sufficient number of conceptions such that those remaining are characterized by institutional convergence.

But the fact of institutional convergence doesn't undermine the thesis of this Part: that different groups of U.S. officials or citizens might possess different conceptions of U.S. law. Those conceptions might all be anchored

${ }^{178}$ Cf. Lynn A. Baker \& Samuel H. Dinkin, The Senate: An Institution Whose Time Has Gone?, 13 J.L. \& POL. 21, 23 (1997) (arguing that "our nation would be better served today by a federal legislature, whether unicameral or bicameral, which afforded the states representation solely in proportion to their shares of the nation's population"). To be sure, the anti-Senate reading of the Fourteenth Amendment just sketched would need to confront the entrenchment of the Senate by Article V. See id. at 67; U.S. CONST. art. V (providing for constitutional amendments subject to proviso that "no State, without its Consent, shall be deprived of its equal Suffrage in the Senate"). But radical readings of the Constitution to circumvent this entrenchment--for example, reading the Fourteenth Amendment as an implicit repeal of the "equal Suffrage" provision in Article $\mathrm{V}$-are certainly thinkable, no less so than the radical readings advanced by the antislavery constitutionalists, or the radical views about constitutional amendments advanced by our Ackermans and Amars.

179 See SEARLE, supra note 113, at 28 (using "institution" in this sense).

180 See BRANDON, supra note 107, at 167-99.

181 Thanks to Matthew Kramer and Eric Posner for pressing me to address this point.

182 On efficacy, see infra text accompanying notes 243-251. 
in the text of the Constitution and overlap in the institutions they recognize, but still diverge. An ultimate rule of recognition is (indeed presumably must be) more than a list of institutions, and the same is obviously true for the sets of legal propositions that can be derived from rules of recognition. Contrast the originalist and nonoriginalist reader of Article I, both of whom recognize a "Congress," composed of a "House of Representatives" and a "Senate," and empowered to regulate interstate commerce, but who disagree profoundly about the scope of that power. ${ }^{183}$ Or, contrast unitarian and nonunitarian interpretations of Article II, both acknowledging a "President" exercising the "executive" power, but disputing whether that means the power to constrain the policy choices of every nonjudicial and nonlegislative official in the U.S. government through binding directives and the threat of removal, or the power to do so only with respect to officials that Congress has chosen not to insulate from presidential policy control. ${ }^{184}$

So much for "constitutive" rules and Searlean groups. As for Lewisconventions ${ }^{185}$ : the jurisprudential critics of Hart's understanding of the rule of recognition as a Lewis-convention are certainly correct that some elements of a given person's views about fundamental law are likely to be nonconventional. ${ }^{186}$ On the other hand, fully specified constitutional views plausibly will have some conventional elements. Let's call $C_{l}$ the set of propositions of constitutional law generally accepted by group $G_{1}$. Then it might well be the case that each member of $G_{1}$ would accept $C_{1}{ }^{\prime}$ instead were she to believe that everyone else in $G_{1}$ accepts $C_{1}$ '. Further, in this example, the conventionality of $C_{1}$ is internal to $G_{1}$, in the sense that each member accepts whichever constitutional conception the other members accept, even though one or perhaps both isn't fully accepted by outsiders. It would follow that $G_{1}$ and a different group, $G_{2}$, could have distinct constitutional conceptions, each internally conventional.

A stylized example: the Republicans and the Democrats have different generic approaches to constitutional interpretation, originalist and nonoriginalist. The acceptance within each party of the generic approach is not conventional, but the acceptance of a particular conception is (for example, the choice for Republicans between original-intention and original-meaning variants of originalism ${ }^{187}$ ). Republicans accept their particular conception

${ }^{183}$ See United States v. Lopez, 514 U.S. 549, 584 (1995) (Thomas, J., concurring) (rejecting "substantial effects" test for the scope of the Commerce Clause on originalist grounds).

184 Compare Geoffrey P. Miller, Independent Agencies, 1986 SUP. CT. REV. 41, 44-45, with Peter M. Shane, Independent Policymaking and Presidential Power: A Constitutional Analysis, 57 GEO. WASH. L. REV. 596, 608-23 (1989).

${ }^{185}$ On the structure of Lewis-conventions, see LEwIS, supra note 40, at 5-82; EDNA ULLMANNMargalit, The Emergence of Norms 74-133 (1977); Robert Sugden, Conventions, in 1 THE New PALGRAVE DiCTIONARY OF ECONOMICS AND THE LAW 453 (Peter Newman ed., 1998).

186 See supra note 112 and accompanying text.

187 See Paul Brest, The Misconceived Quest for the Original Understanding, 60 B.U. L. REV. 204, 205-18 (1980) (distinguishing between different variants of originalism). 
because other Republicans do, and Democrats do the same, both in the teeth of the other party's disagreement.

Finally, the possibility that the social fact undergirding law might be a social norm should be mentioned. There is a burgeoning literature on social norms, ${ }^{188}$ where these are (roughly) rules that a group conforms to because many of its members approve of conformity and disapprove of nonconformity. ${ }^{189}$ Paradigmatically, norms rest on moral approval and disapproval: consider antilittering norms, or current norms (in some communities) against spanking. Norms are different from Lewis-conventions, although the two categories may overlap. ${ }^{190}$ They are also different from SCAs and "constitutive" rules. Despite the intense contemporary scholarly interest in social norms, jurisprudents have not discussed whether the rule of recognition might be understood as a social norm. Might not the social-norm construal of the rule of recognition be consistent with its status as a social practice of some kind, and yet also account for the fact that certain fundamental propositions of U.S. law are more than conventionally entrenched: that many individuals would continue to accept these propositions even if they weren't generally accepted? This is not a line of inquiry I can pursue here. Rather, the point I wish to make, a very obvious one, is that multiple groups can simultaneously follow their own distinct norms concerning the proper interpretation of the Constitution, such that each group's members approve conformity to its interpretive norm and disapprove of deviation.

\section{EXPLANATORY LAW-TALK, NORMATIVE LAW-TALK, AND THE GROUP-RELATIVE VIEW OF LAW}

Part II demonstrated that groupings of diverse sorts (judicial, official, citizen) could simultaneously engage in a distinctive kind of social practice, the kind that gives rise to law; and that this picture resonates with U.S. constitutional history, characterized by the clash of constitutional conceptions advanced by competing parties, branches, governments (state or federal), regions, churches, constitutional reform movements, and other groups. But do these competing practices really create competing bodies of U.S. constitutional law? It is one thing to say that the sort of social fact which gives

188 See Matthew D. Adler, Expressive Theories of Law: A Skeptical Overview, 148 U. PA. L. REV. 1363, 1373 n.44 (2000) (citing law and norms literature). For an excellent, recent review article, see Richard H. McAdams \& Eric Rasmusen, Norms in Law and Economics, in HANDBOOK OF LAW AND ECONOMiCs (A. Mitchell Polinsky \& Steven Shavell eds., forthcoming 2006).

189 This conception of norms, which incorporates an attitudinal condition, has the virtue (among others) of distinguishing them from mere conventions or, more generally, mere Nash-equilibria. See McAdams \& Rasmusen, supra note 188, at 3-4. Philip Pettit and Richard McAdams have provided rigorous accounts of norms hinging on the attitudinal condition. See Richard H. McAdams, The Origin, Development, and Regulation of Norms, 96 MICH. L. REv. 338, 355-76 (1997); Philip Pettit, Virtus Normativa: Rational Choice Perspectives, 100 ETHICS 725, 742-53 (1990).

190 See LEwIS, supra note 40, at 97-100; Sugden, supra note 185, at 456-57. 
rise to law is multiply realizable, quite another, to say that, when multiple realization occurs, we genuinely have multiple (fine-grained) legal systems.

Law-talk occurs in different contexts and for different purposes. At a minimum, and most fundamentally, law-talk can be (1) predictive/explanatory or rather (2) normative. ${ }^{191}$ An assertion about U.S. constitutional law, for example that "under the U.S. Constitution, a statute is enacted if passed by a majority of the Congress and signed by the President," might be made in the course of predicting how political actors will behave or explaining how they have behaved. The assertion will claim the existence of some kind of social fact: for example, some more or less robust collective intentionality on the part of the actors, involving their mutual recognition of the entities "President," "Congress," and "statute," the mutual belief that a statute is valid if approved by both Congress and the President, and a mutual professed intention to comply with statutes. That social fact could explain, for example, why the actors make efforts to comply with statutes, or at least to conceal noncompliance, and why they publicly urge or presuppose compliance and criticize noncompliance. The assertion about constitutional law, via the social fact or practice which is thereby asserted, attempts to shed light on individual behavior (both physical behavior, here the physical behavior that the statutes prohibit, and expressive behavior, here the actors' statements about compliance).

But the very same assertion, "a statute is enacted if passed by a majority of the Congress and signed by the President," could also be voiced as a normative assertion. It could be uttered in the course of recommending that someone engage in, or refrain from, some activity. For example: citizens ought not violate some rule of conduct, and government officials ought to

191 There is a substantial recent literature about the methodology for jurisprudence, and the question whether "law" is a normative construct, an explanatory construct, or something else is central to this literature. See ColEMAN, supra note 50, at 175-217; JULIE Dickson, EVALUATION AND LEGAL THEORY (2001); Brian Leiter, Legal Realism, Hard Positivism, and the Limits of Conceptual Analysis, in HART'S POSTSCRIPT, supra note 58, at 355; Perry, supra note 58; Jeremy Waldron, Normative (or Ethical) Positivism, in HART'S POSTSCRIPT, supra note 58, at 410; see also Greenawalt, supra note 44, at 662-70 (distinguishing between "sociologist's account" and "participant's account" of constitutional law).

My claim is not that a concept named "law" can only play a predictive/explanatory or a normative role. It may be, for example, that there is a descriptive variant of law-talk that is different from both the explanatory and the normative variants. "Law" might be a term we use to describe a kind of social reality without recommending or predicting anything. But it's hard to know what criteria we'd use to regiment the construction of descriptive as opposed to explanatory or nornative constructs. See Perry, supra note 58, at 327-38. And it's hard to see why the pure description of social reality, without any claims that the description illuminates causal mechanisms-in other words, has explanatory powershould be of much interest for scholars. In any event, my group-relative account of law is offered and defended as a reconstruction of two central variants of law-talk, the normative and the explanatory/predictive, and not as a reconstruction of all possible variants. It does seem plausible that, if the group-relative account best reconstructs normative and explanatory/predictive legal discourse, then--if only as a matter of consistency-purely descriptive legal discourse should also be understood as grouprelative rather than assuming a canonical group. But this suggestion, and more generally the nature of purely descriptive legal discourse, are not matters I can pursue here. 
sanction them for noncompliance, since the rule has been passed by a majority of the Congress and the President and is therefore a statute.

Law professors who make claims about U.S. constitutional law are typically engaged in normative discourse, discourse that recommends and evaluates and tells actors what they ought to do. Political scientists, to the extent that they make claims about U.S. constitutional law, are typically engaged in a predictive/explanatory discourse. To be sure, one of the things political scientists may want to explain is why people make certain normative statements or have certain normative attitudes (e.g., reverence for the "Framers"); but of course explaining a normative statement or a normative attitude is not the same as making the statement or having the attitude. The two discourses are different. And separating them will help us think clearly about whether constitutional law is group-relative.

\section{A. Law as a Predictive/Explanatory Concept}

Consider first the predictive/explanatory variant of constitutional discourse. An important, threshold question is whether social facts have a useful role to play in political science and social science more generally. Reductionists about social-scientific explanation, such as Jon Elster, argue that good explanations invoke only individual-level facts, particularly individual beliefs and preferences. ${ }^{192}$ Holists, such as Philip Pettit, disagree, arguing that social facts have a legitimate explanatory role. ${ }^{193}$ For example, social facts may compactly summarize a complicated network of individual preferences and beliefs; assertions about Lewis-conventions do just this, and so do assertions about social norms as they are understood by rationalchoice theorists. Or it may emerge that preferences and beliefs are inadequate to explain individual choice and that psychological entities such as "intentions," "decisions," "plans," or "commitments" have an explanatory function as well. ${ }^{194}$ Social facts such as SCAs are complicated networks of these sorts of entities, and if such commonsense entities indeed do some social-scientific work that preferences and beliefs cannot, the sorts of social facts that are supervenient on intentions, decisions, and so on could usefully summarize them.

Sociologists are holists, while many economically minded political scientists are reductionists. Entering this thorny, methodological debate is well beyond the scope of this Article. ${ }^{195}$ The point I will make is therefore

192 See JON ELSTER, NUTS AND BOLTS FOR THE SOCIAL SCIENCES 3-10 (1989).

193 See Philip PetTIT, The COMMON MIND: AN ESSAY ON PSYChOlogy, SOCIETY AND POlitics 228-83 (1993).

194 See id. at 239-48 (defending "inference-theoretic" account of choice rather than classic decisiontheoretic account, which explains choice as a product of preferences and beliefs measurable as utilities and subjective probabilities).

195 For some recent literature, see Symposium, Explanations and Social Ontology, 18 ECON. \& PHIL. 209 (2002). See also Brian Leiter, Legal Realism and Legal Positivism Reconsidered, 111 ETHICS 
conditional: if the holists are right, and social facts have some useful role to play in explaining the behavior of U.S. political actors, there is no reason to presuppose that social facts about some canonical grouping have explanatory priority. By this I mean: (1) social facts about different sorts of groupings (judges, officials, citizens) could be explanatory, if social facts are explanatory at all; and (2) social facts simultaneously realized by multiple groups could be explanatory, if social facts are explanatory at all.

Consider, for example, the Raz/Kutz view that the rule of recognition is a rule for judges: that the canonical recognitional community is composed of judges (most plausibly, in the U.S. context, federal judges). Taken as an explanatory axiom, an axiom of political science, this means that a certain sort of social fact about federal judges - their shared constitutional conception, embodied in an SCA or variant, Searlean collective intentionality, a Lewis-convention, or a social norm-is properly invoked to explain what the judges do, while the same sort of social fact about nonjudicial officials should not be invoked to explain what nonjudicial officials do. Such an axiom, I suggest, would be absurd. Assume that judges agree on some proposition of constitutional law (e.g., federal law is supreme over state law), and this proposition is integrated into the right sort of social practice among judges. Then, plausibly, that social fact would help explain why an individual judge behaves consistently with the proposition, why she tends to avow it and reach decisions that can be rationalized as consistent with it. Not only does everyone in the group believe the proposition, as could occur if the group were simply a random collection of individuals, but the proposition has a certain resilience for each individual judge that derives from the structure of the social practice among the judges. She can expect to be criticized if she disavows it (social norm); she knows that other judges believe the proposition, can count on each of them not to disavow it perfunctorily, and intends herself not to disavow it perfunctorily (SCA); and so on.

But then the very same explanatory schema will be useful, or might be useful, in predicting/explaining the behavior of nonjudicial officials or citizens. A group of nonjudicial officials, or citizens, might agree on some proposition of constitutional law. The kind of social practice constituting the judicial rule of recognition (be it an SCA or variant, Searlean collective intentionality, a Lewis-convention, or a norm) might also characterize this nonjudicial group, as I tried to show above. Further, the agreed-upon proposition might be integrated into that practice. It will therefore plausibly be resilient for each member of the nonjudicial group, and will help explain her decisions and avowals, just as the judicial rule of recognition explains judicial decisions and avowals.

The political scientist who insists on the Raz/Kutz axiom is in a particularly odd position when federal judges are engaged in constitutional

278 (2001) (interpreting the Realists as defending "empirical rule-skepticism," the view that legal rules don't cause judicial decisions). 
conflict with nonjudicial actors. Such conflicts, as I have already suggested, are a recurrent feature of U.S. constitutional life. Nonjudicial actors frequently contradict the constitutional claims asserted by judges, be they claims about constitutional rights (school prayer, abortion) or about constitutional structure (the scope of federal power, the separation of powers) or about judicial review and supremacy itself. Sometimes these nonjudicial actors, or some of them, are organized into one or more collectivities that are internally bonded as tightly as judges are, perhaps more tightly. By virtue of internal conventions, norms, or collective intentions, these collectivities are genuine groups, no less so than the federal judiciary. Witness constitutional conflicts between the Supreme Court and the Presidency; between the Court and Congress, or partisan or leadership groups within Congress; between the Court and state governments, or branches of state governments; or between the Court and constitutional reformers. ${ }^{196}$ The political scientist who is a (partial) holist about social-science explanation, and countenances appeals to social facts, but accepts the Raz/Kutz axiom, would generate an oddly hybrid explanation of constitutional conflicts between judges and nonjudges. Individual judges avow some constitutional proposition partly because of a social practice among judges that supports the proposition; but individual citizens or nonjudicial officials, in conflict with the judiciary, avow some contradictory proposition solely because of individual-level explanans, that is, individual preferences, beliefs, and intentions. "The Court" remains a legitimate social-scientific grouping, properly deployed to explain political conflict about the meaning of the Constitution, but "the President," "the Senate Judiciary Committee," "NOW," or "the South Carolina legislature" are ruled out.

Perhaps the best that can be said in defense of the Raz/Kutz axiom is: judges' motivations are different. Judges know and care about the Constitution in a unique way. Nonjudicial officials are more self-seeking, and citizens are more ignorant. Therefore social practice among judges, targeted at the Constitution, will have a uniquely powerful predictive/explanatory role. But much political science impugns this exceptionalist picture of judges. ${ }^{197}$ Just as legislators care about reelection, so too judges care about keeping their offices (not a trivial point in the case of elected state judges ${ }^{198}$ ), or being appointed to a higher bench. Just as judges also have public-regarding aims, so do legislators and, certainly, Presidents; and constitutional views, not simply the "policy" goal of maximizing social welfare or some such construct, can figure in the publicregarding aims of legislators and Presidents. As for citizens: pure patriotism or, more likely, a mix of self- and public-regarding motives isomorphic

196 See supra text accompanying notes 122-162.

197 See Whittington, supra note 1, at 812-27.

198 See Steven P. Croley, The Majoritarian Difficulty: Elective Judiciaries and the Rule of Law, 62 U. CHI. L. REV. 689 (1995). 
to the official mix can and (as evidenced by citizen constitutional activism) sometimes does overcome the default position of rational ignorance.

In any event, even if judges are specially motivated, and it therefore follows (for some reason) that social practice among judges concerning constitutional law is uniquely explanatory of judicial behavior, this is hardly an a priori or settled fact. Good political science should be open to the possibility that judges, officials, and citizens might have a range of motivations, and if good political science is partly holistic then it should be open to the possibility that conventions, norms, or collective intentionality targeted at the text of the Constitution could be explanatory in all these cases, not just in the case of judges. Thus the Razian/Kutzian identification of judges as the canonical recognitional community, ${ }^{199}$ taken as an axiom of socialscientific practice, is deeply problematic. For very much the same reasons, the Hartian identification of officials as the canonical recognitional community, and the Dworkinian identification of citizens as that canonical grouping, once more taken as axioms of good social science, are also deeply problematic.

\section{B. Law as a Normative Concept}

What if we switch from predictive/explanatory law-talk to normative law-talk? Hart saw his enterprise as explanatory or at least nonnormative-he characterized The Concept of Law as a piece of "sociology"200_but Dworkin's ambitions were squarely normative, to understand the conditions under which law creates genuine reasons for action. ${ }^{201}$ Further, it seems quite plausible that those reasons for action would consist in, or at least include, moral reasons. Dworkin himself certainly sees law's normativity as a kind of moral normativity. He argues, remember, that communities can create associative moral obligations for their members. ${ }^{202}$ And Raz has famously asserted that law necessarily claims moral authority. ${ }^{203}$

The Razian position, which I find quite plausible, clearly does not imply that law actually has moral authority - that it actually generates moral reasons in some way. But the Razian position does seem to mean this: the reasons which participants in normative legal discourse assert to exist are

199 The adjective "Razian" here must be used with some care. Raz does think of judges rather than officials or citizens as the recognitional community but, as noted earlier, suggests that there might different groups of judges accepting different rules of recognition-so in that sense departs from the canonical view. See supra text accompanying note 103.

200 See HART, supra note 5, at v; see also id. at 239-40 (Postscript) (stating that book's aim was descriptive and morally neutral); Perry, supra note 58, at 312-25 (discussing nature of Hart's project).

201 See DWORKIN, supra note 80, at 87-113; HART, supra note 5, at 240-44 (discussing Dworkin's project); Perry, supra note 58, at 349-51 (same).

202 See supra text accompanying notes 86-91.

203 See Kenneth Einar Himma, Law's Claim of Legitimate Authority, in HART'S POSTSCRIPT, supra note 58, at 276. But see HART, supra note 5, at 202-03. 
(or at least include) moral reasons. I will therefore focus, in this section and hereafter, on normative legal discourse understood as a discourse that ascribes moral authority to law. I conjecture, but will not try to demonstrate, that my analysis carries over to normative legal discourse (if such exists) that cites law as a source of nonmoral reasons, for example reasons of selfinterest.

There is some dispute about the structure of the moral authority that law might possess and that normative legal discourse claims. Does law purport to create ordinary, first-order moral reasons, on a par with other moral considerations? Or are these reasons special, higher-order reasons: so-called exclusionary reasons? Or maybe these reasons are not substantive reasons at all. Perhaps law's moral authority is "theoretical" rather than "practical." $" 204$ I will not take a position in these disputes and will simply assume that normative legal discourse - in particular, normative claims about the U.S. Constitution - asserts that law has some kind of moral authority.

There is a great debate within modern moral theory about whether morality is consequentialist in its structure. ${ }^{205}$ The terms of this debate provide a useful way to categorize theories of law's moral authority. Some such theories are generic, in the sense that they're consistent with both consequentialist and nonconsequentialist moral views. Others are not. As it happens, the most important nongeneric authority accounts have drawn upon nonconsequentialist moral notions such as consent, fair play, and special duties.

The two examples of generic accounts of authority at play in the contemporary scholarly literature are epistemic and coordinative accounts. The epistemic account says that lawmakers have moral expertise, in some way, and that legal duties and other legal positions are authoritative in virtue of tracking preexisting moral requirements. ${ }^{206}$ The coordinative account (in effect) invokes law's function in solving moral coordination problems: situations where there are two or more joint courses of action $R_{1} \ldots R_{\mathrm{n}}$, such that each member of a group $G$ is morally required to follow whichever one of these the other members of the group follow. ${ }^{207}$ The coordinative account

204 In other words, authoritative directives might create first-order reasons for action, second-order reasons for action (thus the "exclusionary" model of authority), or first-order reasons for belief (thus the "theoretical" model of authority). See Heidi M. Hurd, Challenging Authority, 100 YALE L.J. 1611, 1615-20 (1991) (distinguishing these possibilities). A fourth possible model of authority should be noted: that authoritative directives provide second-order reasons for belief. All four models have been defended in recent years. See id. at 1667-77 (first-order reasons for belief); Michael S. Moore, Authority, Law, and Razian Reasons, 62 S. CAL. L. REV. 827, 871 (1989) (first-order reasons for action); JOSEPH RAZ, THE MORALITY OF FREEDOM 23-69 (1988) (exclusionary reasons); Donald H. Regan, $A u$ thority and Value: Reflections on Raz's Morality of Freedom, 62 S. CAL. L. REV. 995, 1001-18 (1989) (second-order reasons for belief).

205 See Shelly Kagan, Normative ETHics 25-152 (1998).

206 See, e.g., RAZ, supra note 204, at 53-57, 70-80; Hurd, supra note 204, at 1667-77.

207 See, e.g., LESLIE GREEN, THE AUTHORITY OF THE STATE 89-121 (1990); RAZ, supra note 204, at 49 . On the possibility of moral coordination problems, see DEREK PARFIT, REASONS AND PERSONS 
of law's authority is most naturally paired with the view that law rests on a Lewis-convention, but can also be matched with SCAs, "constitutive" rules, or social norms.

As for nonconsequentialist accounts of authority: the most influential account of this kind, historically, has been the consent-based account, deriving from Locke, which asserts that (some of) those persons subject to the laws of a given polity have consented to follow those laws and are therefore genuinely morally obligated to do so. ${ }^{208}$ The difficulty for this theory, at least in explaining law's authority over mere citizens or subjects rather than officials, is that very few nonofficials expressly consent to follow the laws, and modern theorists tend to think that consent-based views which look to tacit or hypothetical consent are problematic. ${ }^{209}$ Consent is binding, if it is, as a deliberate promise or commitment; hypothetical consent appeals to the promises individuals would make, not those they actually do, while tacit consent views succeed in substantially widening the scope of obligation beyond express consent only by construing the exercise of important freedoms, such as the freedom to vote or to refrain from emigrating, as promises to obey. Modern nonconsequentialist accounts of authority have sought to overcome the deficiencies in the consent-based view by identifying circumstances in which citizens would be morally bound to obey the law even without a promise to do so. One important such account, building on Hart and Rawls, points to the putative duty of fair play-the moral duty to do one's part in social arrangements the benefits of which one has accepted. ${ }^{210}$ Another is Dworkin's associative account, arguing that the members of a political community may have a fraternal duty to obey those norms identified as law by the best "interpretation" of the community's practices. $^{211}$

On the canonical view, normative legal discourse has the following structure: (1) the canonical group (be it citizens, officials, or judges) is invoked; (2) it is asserted that the group instantiates the right sort of social fact (be it an SCA or variant, a Lewis-convention, Searlean collective intentionality, or a social norm); (3) it is asserted that some legal position is derivable from this social fact; and (4) it is asserted that the legal position has some kind of moral authority (epistemic, coordinative, consent-based, fairplay based, associative, or other) for some persons holding that position. I now want to suggest that the initial restriction on which groups can be invoked to ground moral authority claims is arbitrary. Not only can different types of groups instantiate the sort of social fact undergirding law-as was

(1984); DONALD REgAN, UTILITARIANISM AND COOPERATION 17-21 (1980); William S. Boardman, Coordination and the Moral Obligation to Obey the Law, 97 ETHICS 546, 549-55 (1987).

208 See, e.g., GREEN, supra note 207, at 158-87; RAZ, supra note 204, at 80-94.

${ }^{209}$ See, e.g., DWORKIN, supra note 80, at 192-93; GREEN, supra note 207, at 161-73; RAZ, supra note 204 , at $94-97$.

210 See A. John Simmons, The Principle of Fair Play, 8 PHIL. \& PUB. AfF. 307 (1979).

211 See DWORKIN, supra note 80, at 186-215. 
demonstrated in Part II-but the legal positions derivable from the different groups' practices can be genuinely authoritative for some persons holding those positions. Indeed, multiple groups, all part of the same coarsegrained legal system-specifically, all advancing conceptions of U.S. law, grounded on the U.S. Constitution and purporting to govern U.S. territorycan simultaneously engage in practices such that the legal positions derivable from each of the practices are morally authoritative for some of the persons holding the positions.

In short, no one type of group advancing a conception of U.S. constitutional law is uniquely capable of possessing moral authority; nor is it even true that one particular (token) group advancing a conception of U.S. constitutional law is uniquely capable of possessing moral authority at a particular time. So the canonical, as opposed to group-relative, schema for normative constitutional discourse is arbitrary.

Is it true that different groups' conceptions of constitutional law can have pervasive authority: that is, the positions validated by these conceptions are genuinely morally authoritative for all the persons holding the positions? Perhaps not. Authority may well be piecemeal. ${ }^{212}$ Duty $D$ may be authoritative for person $P_{1}$ but not $P_{2}$-for example, if $P_{1}$ is morally inexpert or has consented to $D$, but $P_{2}$ is morally expert and has not consented. But the piecemeal cast of authority doesn't salvage the canonical schema, since different types of groups can have piecemeal authority, and different groups can have piecemeal authority at a particular time. What about the possibility of conflicting legal positions generated by the constitutional conceptions of different groups, where the conflicting positions are all simultaneously authoritative for the same person? Intuitively, this is not possible. For example, it seems impossible for a legal duty requiring the performance of particular action $A$ by person $P$ and a conflicting duty prohibiting $P$ from performing $A$ to be authoritative for $P$. The intuition may well be wrong. ${ }^{213}$ In any event, even if it is impossible for conflicting legal positions to simultaneously possess moral authority for the same person, this hardly undermines the group-relative schema for normative constitutional discourse. As long as one group's conception of constitutional law can have moral authority with respect to some of the legal positions it gen-

212 See RAZ, supra note 204 , at 74, 77-78, 100.

213 Simultaneous authority for conflicting duties would be possible if law's authority consists in first-order reasons for action. I might have a prima facie reason to perform action $A$ and a conflicting, prima facie reason to refrain from action $A$. It would also be possible if law's authority consists in firstorder reasons for belief. Two groups, both with some degree of moral expertise, give me conflicting advice. Aren't the conflicting statements both evidence, if not conclusive, of what I should do? Finally, if law's authority consists in second-order reasons for action (the exclusionary-reason model) or for belief, conflicting duties can be simultaneously authoritative with respect to different parts of morality. See RAZ, supra note 204 , at 46 (noting that authoritative directives "may be designed not finally to determine what is to be done in certain circumstances but merely to determine what ought to be done on the basis of certain considerations"). 
erates, for some persons, and a different group's conception can simultaneously have moral authority for some of the legal positions it generates, for some persons, nothing in the notion of authority-in the normativity of normative legal discourse-would warrant a restricted schema permitting only a single group to be invoked.

Is it true that the constitutional conceptions of different groups can simultaneously possess moral authority? Consider first the epistemic account. Different groups might possess moral expertise with respect to different moral issues. Expertise might be first-order expertise, about substantive moral questions, or higher-order expertise: expertise in identifying the groups that have first-order expertise or are morally authoritative in some other way. A long-running theme in the literature on judicial review is that the Supreme Court has comparative moral expertise, relative to legislatures, in delineating the contours of certain basic moral rights or valuesequal concern and respect; free speech; democratic participation; privacybut not with respect to other moral rights or values, paradigmatically efficiency or overall welfare. ${ }^{214}$ To be sure, the precise contours of these domains are contested. But as long as some individuals face choices implicating moral rights or values as to which courts are comparatively expert, ${ }^{215}$ and other individuals face choices implicating moral rights or values as to which legislatures are comparatively expert, legal duties or liberties flowing from judicial constitutional conceptions could have epistemic authority for some individuals while legal duties or liberties flowing from legislative constitutional conceptions could have epistemic authority for others.

Some very simple examples: One official is conducting an administrative adjudication and is trying to determine whether to provide an oral hearing-required by Supreme Court doctrine, but prohibited by the official's organic statute. Another is trying to decide whether to regulate certain advertisements that are true but may lead to consumer welfare losses-a regulation required by statute, but prohibited by Court doctrine. A third is running a prison and is considering whether to temporarily segregate prisoners by race to prevent race riots - a measure required by statute, but prohibited by doctrine. If, in the first two cases, it is true (and the officials

${ }^{214}$ See, e.g., BICKEL, supra note 143, at 23-28 (judges have comparative expertise with respect to matters of principle); DWORKIN, supra note 80, at 374-76 (moral rights); JOHN HART ELY, DEMOCRACY AND DISTRUST 101-04 (1980) (procedural rather than substantive rights); United States v. Carolene Prods. Co., 304 U.S. 144, 152-53 n.4 (1938) (the evaluation of laws restricting the political process or targeted at discrete and insular minorities); LAWRENCE G. SAGER, Justice IN Plainclothes: A THEORY OF AMERICAN CONSTITUTIONAL PRACTICE 1-11 (2004) (some but not all aspects of constitutional justice, which is a proper subset of full political justice, which is in turn a proper subset of moral considerations generally); see also Adler, supra note 2, at 882-91 (identifying persistent suggestion in literature on judicial review that legislatures are better, ceteris paribus, at resolving constitutional questions that involve issues of "legislative fact").

215 There are deep issues here about whether expert $E$ 's epistemic authority for subject $S$ depends on $S$ 's beliefs and information or not. However these issues are resolved, different experts can simultaneously be epistemically authoritative for different actors or on different issues. 
believe) that their choices implicate nothing more than welfare maximization, while in the third case it is true (and the officials believe) that equality is at stake, ${ }^{216}$ then the legislative conception of constitutional rights would be epistemically authoritative in the first two cases, while the Supreme Court conception would be epistemically authoritative in the third.

Consider next the coordinative account. This view of moral authority has considerable currency in constitutional theory. It is the view that Larry Alexander, Fred Schauer, and David Strauss advance in describing law's settlement function. ${ }^{217}$ The point I wish to stress is this: multiple groups can face moral coordination problems, and Lewis-conventions or other facts about each of the groups can generate legal positions that have coordinative authority for members (and perhaps outsiders too). For example, the populace as a whole faces a moral coordination problem in deciding who the President is. Within broad limits, each of us should recognize as President the particular person that everyone else in the populace does. More precisely, certain decisions by the natural person that virtually everyone in the population recognizes as President will have moral weight for everyone in virtue of this collective recognition. At the same time, smaller groups will face their own moral coordination problems, and Lewis-conventions or other social facts about these groups will have coordinative authority internally and perhaps externally. ${ }^{218}$ Judges will face coordination problems with respect to the process of adjudication; the same goes for legislators and legislation. If virtually every judge believes that original and appellate jurisdiction is constitutionally divided among the courts in a certain way, then each judge (and everyone else) has a moral reason to follow that scheme. ${ }^{219}$ If virtually every legislator believes that a certain category of legislation

${ }^{216}$ See Cent. Hudson Gas \& Elec. v. Pub. Serv. Comm'n, 447 U.S. 557 (1980) (arguably adopting a welfare-maximization rationale for the constitutional protection of commercial speech); Mathews v. Eldridge, 424 U.S. 319 (1976) (arguably adopting a welfare-maximization view of procedural due process); DworkIN, supra note 92, at 227 (arguing that Equal Protection Clause embodies a right to equal concern and respect); $c f$. Cass Sunstein, The Anticaste Principle, 92 MiCH. L. REV. 2410 (1994) (arguing that Fourteenth Amendment embodies an anticaste principle, albeit one that the legislature should take the lead in enforcing).

217 See Alexander \& Schauer, supra note 21, at 1369-81; David A. Strauss, Common Law, Common Ground, and Jefferson's Principle, 112 YALE L.J. 1717, 1731-40 (2003).

${ }^{218}$ A group practice $R$ has coordinative moral authority for group members, i.e., "internally," if everyone in the group has moral reason to conform to $R$ because everyone else in the group conforms to $R$, but would have moral reason to conform to $R^{\prime}$ if everyone else in the group conformed to $R^{\prime}$. A group practice has coordinative moral authority for some nonmembers, i.e., "externally," if those nonmembers have moral reason to conform to $R$ because everyone in the group does, but would have moral reason to conform to $R^{\prime}$ if everyone in the group did. In the first case, group members have a reciprocal role in creating moral reasons for each other. In the second case, group members have a nonreciprocal role in creating moral reasons for outsiders: whether outsiders should conform to $R$ depends on whether members do, but whether members should conform to $R$ doesn't depend on whether outsiders do.

${ }^{219}$ Cf. U.S. CONST. art. III, $\$ 2$, cl. 2 (addressing original and appellate jurisdiction of the Supreme Court). 
must, constitutionally, originate in the House, then every legislator (and everyone else) has a moral reason to respect that allocation. ${ }^{220}$

It might be objected that Lewis-conventions within a group, or other facts about a group, have coordinative authority for the group members or outsiders only if certain background facts hold true, including social facts about other groups. For example, if a segment of the citizenry were prepared to die for the proposition that certain matters should originate in the House, not the Senate, then legislative practice with respect to origination might lack coordinative authority for legislators and others. Regardless of the shape of legislative practice, individual legislators might have moral reason to risk legislative chaos and insist that the matters should originate in the House, since civil unrest provoked by legislative practice in the teeth of the violent citizens' preferences would be the worst outcome of all. But this point - that group practices depend on favorable background facts for their coordinative authority-is no less a problem for the canonical account. Imagine that we take the large grouping of the citizenry as a whole as the canonical group. There are outsiders to this grouping: namely, the rest of the world's population. Social facts about this background group might vitiate the coordinative authority of citizen practices. If foreigners were bent on using nuclear weapons to destroy Washington in the event that a particular person were recognized as President, would individual citizens have moral reason to recognize that particular person as President once the rest of the citizenry did?

The claim that the practices of a given group possess coordinative authority is not a "modal" claim-a claim that, in all possible worlds, the practices possess coordinative authority. It is rather that, against the actual background, individual group members (and perhaps others) have moral reason to follow rule $R$ because everyone else in the group follows $R$, but would have moral reason to follow $R^{\prime}$ instead if everyone else in the group followed $R^{\prime}$. Multiple groups can simultaneously possess coordinative authority in this sense.

Turn now to nonconsequentialist accounts of authority: consent, fair play, and associative duty. If consequentialism about morality is correct, then law will lack moral authority in any of these ways - but that hardly argues for the canonical as opposed to group-relative account of legal discourse. Assume nonconsequentialism. On this assumption, the consentbased view ends up being plausible as a theory of why law is morally authoritative for officials, since officials in many legal systems do expressly promise to uphold the law. Indeed, Article VI of the Constitution says that state and federal officials are required to do so. ${ }^{221}$ By contrast, the fair-play

220 Cf. id. art. $1, \S 7$ (addressing origination of revenue bills).

221 See id. art. VI, $\$ 3$ ("The Senators and Representatives before mentioned, and the Members of the several State Legislatures, and all executive and judicial Officers, both of the United States and of the several States, shall be bound by Oath or Affirmation, to support this Constitution ...."). 
and associative accounts would be plausible as accounts of law's moral authority for citizens.

The worry for the group-relative view, here, is that each account does identify a unique canonical group: all officials for the consent-based view, all citizens for the others. But this may not be right. As for officials, the moral content of the Article VI promise may (perhaps) vary depending on which SCA (or other social grouping) the promising official belongs to. Federalism becomes relevant. Imagine that South Carolina officials instantiate an SCA with a states' rights conception of the Constitution, one that sees the Article VI oath they have taken as a promise to other South Carolinians. At the same time, Vermont officials instantiate a symmetrical SCA, viewing their Article VI oath as a promise to other Vermonters. Might it not follow, then, that South Carolina officials have a promissory duty to each other to support the South Carolina conception of the Constitution, while the Vermont officials have a symmetrical duty to support the Vermont conception? Federalism also has relevance for fair-play and associative duties. If the U.S. citizenry generally can be an SCA (or some other appropriate type of social group) that fraternally binds members to the best "interpretation" of the group's preinterpreted practices, or obliges them to do their fair share by obeying the law derivative from that SCA, why not the citizenry of each state?

Note, finally, that even if the consent, fair-play, and associative accounts of authority involve a canonical group standing alone, they will not do so in combination with other views. This is a general point. The accounts of authority advanced here are not mutually exclusive. ${ }^{222}$ Law can have epistemic authority and coordinative authority and (if nonconsequentialism is true) consent-based, fair-play, and associative authority as well. For example, an SCA or proto-SCA among citizens as a whole might give each citizen a fair-play duty to obey the primary legal duties validated by this SCA. At the same time, Supreme Court practice might be epistemically authoritative for officials making decisions that implicate equality.

\section{Objections}

My argument to this point has provided a prima facie case for the group-relative view of law. First, as argued in Part II, the social fact that undergirds law (be it an SCA or variant, a Lewis-convention, a "constitutive" rule, or a social norm) can be simultaneously instantiated by multiple groups that derive their legal conceptions from the same basic text (for example, the 1787 U.S. Constitution as amended) and purport to govern the same territory (for example, the territory of the United States). Second, as argued in Part III.A., these simultaneous conceptions can be "law" in the predictive/explanatory sense. If some social facts can play a useful ex-

222 See RAZ, supra note 204, at 75 (identifying multiple possible bases for law's authority). 
planatory role-if the reductionist view which appeals only to individual beliefs, preferences, or intentions is too sparse - then it is very hard to see why predictive/explanatory assertions about "law" should be constrained to invoke social facts about a single, canonical group. The fact that group $G_{1}$ holds conception $C_{1}$ at $T+$ can explain the actions of some of its members at or around that time, while the fact that group $G_{2}$ holds conception $C_{2}$ at $T+$ can explain the actions of some of its members at or around $T+$. Finally, Part III.B argued that legal conceptions held simultaneously by different groups can also be "law" in the normative sense: the fact that $G_{1}$ holds $C_{1}$ at $T+$ can give rise to moral reasons for $G_{1}$ members (or others) at or around $T+$, while the fact that $G_{2}$ holds $C_{2}$ at $T+$ can give rise to moral reasons for $G_{2}$ members (or others) at or around $T+$.

Note that if the existence of simultaneous explanatory or morally authoritative legal conceptions were impossible - either because different groups couldn't simultaneously instantiate SCAs/Lewisconventions/"constitutive" rules/social norms, or because only a single conception could explain behavior or generate moral reasons at a given timethen there would be a canonical group for each moment of time. But the arguments advanced in the preceding sections of this Part demonstrate not merely that different kinds of groups can generate legal conceptions that are explanatory or morally authoritative, but that they can all do so simultaneously. Picking out one of these groups as the canonical recognitional group for a given legal system thus seems quite arbitrary.

But even if this prima facie case for the group-relative account is granted, further objections might defeat that case. I will briefly entertain what seem to be the most important such objections, with apologies to jurisprudentially inclined readers for the brevity. A fuller treatment would make a long Article even longer, and would delay our return to the questions of U.S. constitutional theory which are my ultimate target.

One worry, already touched upon, is that in any stable legal system there must be a substantial degree of overlap among the different groups' conceptions. ${ }^{223}$ For example, in the U.S., at least since our one and only Civil War, most important constitutional conceptions, official or citizen, have shared a basic list of institutions: "Congress," the "President," the "Supreme Court," the "U.S. Government," the particular states. And this may be more than coincidental: a situation in which half the population interpreted the Fourteenth Amendment as trumping Article I, nullifying the Senate, ${ }^{224}$ and half the population insisted that we still had a Senate despite its inconsistency with the principle of one person/one vote, could not long persist, presumably, without violence or anarchy.

But there can be sufficient convergence in groups' conceptions to allow for a stable coarse-grained legal system and no civil war, without complete 
convergence. ${ }^{225}$ Part II demonstrated as much, at length. Indeed, there can be divergence about matters that are quite foundational, without civil warfor example, about the scope of national power ${ }^{226}$ the obligation of nonjudicial actors to obey Supreme Court doctrines and not just case-specific judgments ${ }^{227}$ the difference between constitutional questions and questions of policy, ${ }^{228}$ the existence of unwritten constitutional rights, and the correctness of originalism ${ }^{229}$ as a method for interpreting the Constitution. Each of these has been disputed in the post-Civil War United States, in each case for some substantial stretch of time.

A closely related objection to the group-relative account runs as follows: Why not use the term "law" to mean the area of overlap among different groups' conceptions? Imagine that there are groups $G_{1} \ldots G_{\mathrm{N}}$, with each group $G_{\mathrm{i}}$ generating a set of legal propositions $\left\{P_{\mathrm{i}}{ }^{1} \ldots P_{\mathrm{i}}^{\mathrm{Mi}}\right\}$ that constitutes that group's conception of U.S. law. The group-relative view says that $G_{1}$-relative law is $\left\{P_{1}{ }^{1} \ldots P_{1}{ }^{\mathrm{M} 1}\right\}$, that $G_{2}$-relative law is $\left\{P_{2}{ }^{1} \ldots P_{2}{ }^{\mathrm{M} 2}\right\}$, and so on. Why not say, instead, that U.S. law simpliciter or absolutely is the intersection of these sets?

Although the point is subtle and certainly open to dispute, it seems to me that this "intersection" view of law draws an arbitrary distinctionarbitrary given the two discourses, predictive/explanatory and normative, in which "law" talk figures. Take a given group $G_{i}$ 's conception $\left\{P_{\mathrm{i}}{ }^{1} \ldots P_{\mathrm{i}}^{\mathrm{Mi}}\right\}$. Partition that into two subsets, the first subset consisting of propositions which are shared with all other groups, the second of propositions which are not. Propositions in both subsets might help predict and explain the actions of $G_{i}$ members. For example, the activities of a group of pro-life officials or citizens can surely be explained by their reading of the Due Process Clause even though that reading is far from universally shared. Second, and a little less obviously, the propositions in both subsets might have moral authority for group members. For example, if originalism is the morally correct approach to constitutional interpretation, then each individual judge might have moral reason to follow an original-meaning approach if every other judge does, and an original-intention approach if every other

225 Cf. RAZ, supra note 48, at 118 ("It is evident that two legal systems can coexist, can be practiced by one community. If they do not contain too many conflicting norms it is possible for the population to observe both and the institutions set by both systems could all be functioning. This would in most cases be an undesirable and an unstable situation, but it can exist and it need not always be undesirable or unstable.").

${ }^{226}$ See, e.g., United States v. Lopez, 514 U.S. 549, 584 (1995) (Thomas, J., concurring) (rejecting "substantial effects" test for the scope of the Commerce Clause).

227 See supra notes 145-152 and accompanying text.

${ }^{228}$ Consider the ongoing debate about the scope of substantive due process rights, as recently evidenced in Lawrence v. Texas, 539 U.S. 558 (2003).

229 The correctness of originalism as the methodology for constitutional interpretation, as well as the related question whether unwritten constitutional rights exist, have been hotly debated both inside the legal academy and on the national political scene since the Griswold and Roe decisions. See, e.g., BORK, supra note 171. 
judge does, even if some other officials or citizens are nonoriginalists. ${ }^{230}$ Even more clearly, a group that possesses moral expertise can be epistemically authoritative despite the fact that its views are not universally shared.

Yet another objection to the group-relative account, which I have heard repeatedly and which also draws upon the fact of partial convergence, is that in a stable legal system, or at least in the United States, everyone agrees that the federal courts have the final authority to settle legal disputes. While Cooper v. Aaron has often been contested, the binding force of Supreme Court (and lower federal court) judgments is rarely challenged, at least since the Civil War. ${ }^{231}$ But so what? The corpus of federal court judgments that exist at a given time hardly resolves all the choices that governmental officials or other actors face at that time. Indeed, binding judicial judgments presumably cover only a very, very small fraction of the choices that actors are confronted with at any given time. For example, an official might not, yet, be the subject of a judgment. Perhaps a federal court has ruled in a case with a similar subject matter, but no suit has yet been filed against him. Or it may be that no federal court has ruled on the merits of any case, his or anyone else's, with this subject matter-either because no such case has yet been filed, or because justiciability objections such as standing, ripeness, or mootness would block a case, or because this is an area where legal norms are not judicially enforced, for example by virtue of an explicit "political question" doctrine or doctrines such as rational basis review. ${ }^{232}$ Finally, the official might already have been sued, but the issued judgment might be permissive rather than mandatory with respect to the choice at hand: multiple possible courses of action might be consistent with it. In all these sorts of cases, some group's legal conception can explain/predict what the actor does, or create moral reasons for the actor, even though other groups disagree.

230 The idea here is that (1) originalism is a generic approach to constitutional interpretation, which can be operationalized in a number of specific ways, for example by looking to the original public meaning of constitutional provisions, or alternatively to the subjective intentions of the Framers; (2) judges as a group might face a moral coordination problem in choosing between different specific variants of originalism, in the sense that each judge should follow the specific approach that every other judge follows; and (3) this might be true even if much or at least some of the population of nonjudges are nonoriginalists. On the choice between original-meaning and original-intention variants of originalism, see Brest, supra note 187, at 205-18. On moral coordination problems, see supra text accompanying notes 207, 217-220.

231 See supra notes 22-23 and accompanying text. In the pre-Civil War period, the authority of the Supreme Court to decide cases arising in the state courts was contested. See supra note 140 and accompanying text.

232 Rational basis review and similar underenforcement mechanisms, like an explicit political question doctrine, produce cases where some official action is in fact unconstitutional but the court will refrain from issuing a judgment against it. In the case of rational basis review, the court formally reaches the merits of the challenge, but then sustains; in the case of the political question doctrine, the merits are never reached. But in both instances no binding judgment requiring the official to refrain from the challenged action is issued. On rational basis review as an underenforcement mechanism, see sources cited supra note 14. On the political question doctrine, see Barkow, supra note 16. 
To put the point more concisely: the existence of courts with final adjudicative authority means that many legal disagreements between different groups will eventually be resolved by the courts. But it hardly means that all such disagreements will eventually be thus resolved, given limits to justiciability and to the full judicial enforcement of legal norms. And it certainly doesn't mean that all disagreements are instantaneously resolved, so that there is no space for the competing conceptions to motivate group members or to have moral authority.

A different kind of criticism of the group-relative view is that my prima facie case fails to take account of the difference between law and other socially grounded norms. Law arguably differs from dress norms, standards of etiquette, the rules of clubs and associations, and religious doctrines in having the following conjoined features. Law is coercive, tied to the use of force; it is comprehensive, claiming authority to regulate all manner of human activities; it is institutionalized, involving entities like "the D.C. Circuit" or "Congress"; it is intimately linked to the state (a different point from the last, since clubs and associations can have their own courts and councils); it is systematic, setting forth a "system of interconnecting rules and standards"; ${ }^{233}$ and it is supreme, claiming to trump other norms that might apply to the activities which law governs. ${ }^{234}$ A grouprelative account, even if applicable to dress norms and so on, cannot succeed for law given these distinguishing features - or so it might be argued.

I will not discuss the list in its entirety, but will focus on the feature that seems to create the most trouble for group-relativity: supremacy.

[E]very legal system claims authority to regulate the setting up and application of other institutionalized systems by its subject-community. In other words, it claims authority to prohibit, permit, or impose conditions on the institution and operation of all the normative organizations to which members of its subjectcommunity belong. ${ }^{235}$

A given system of U.S. law claims to settle what individuals located within the territory of the U.S. should do. It does not hold itself out as defeasible by other norms. A system of U.S. law may incorporate the norms of other systems, for example informal social norms or foreign law, but these extrasystemic norms are claimed (by the system) to apply only insofar as U.S. law incorporates them, and not in the teeth of U.S. law.

Therefore, a group cannot characterize the conception of U.S. law that it holds as group-relative - as merely coequal with other groups' conceptions. "Since all legal systems claim to be supreme with respect to their subject-community, none can acknowledge any claim to supremacy over

233 Sean Coyle, Hart, Raz, and the Concept of a Legal System, 21 LAW \& PHIL. 275, 276 (2002).

234 See GREEN, supra note 207, at 78-88; RAZ, supra note 48, at 115-20; RAZ, supra note 74, at 3.

${ }^{235} \mathrm{RAZ}$, supra note 48, at 118. 
the same community which may be made by another legal system." ${ }^{236}$ If a group believed its conception of U.S. law to be merely coequal with other groups', then that conception would not be a conception of law.

The problem here is not unique to the group-relative view. Even if there is a single canonical recognitional community for U.S. law, and thus a single fine-grained legal system that governs U.S. territory at any one time, there can simultaneously exist nonlegal normative systems-in particular, systems of religious law -that claim to govern (some) U.S. citizens and that assert supremacy in the sense just described. For that matter, legal systems that assert extraterritorial authority (over their citizens abroad) make claims of supremacy that can come into conflict with those of legal systems that govern all subjects located within a territory.

Further, the problem is closely related to a second problem that, again, affects traditional accounts of law: namely the disjunction between law's asserted and actual moral authority. Raz suggests, plausibly, that law not only claims moral authority but does so in a strong way, namely by claiming to create moral obligations. "[I]t claims that legal requirements are morally binding, that is that legal obligations are real (moral) obligations arising out the law." ${ }^{237}$ But the scholarly literature on authority describes various ways in which law may fail to create binding moral obligations. Law's authority may well be "theoretical" rather than "practical"; 238 it may be piecemeal rather than universal; ${ }^{239}$ law may only create moral reasons that are defeasible by other moral considerations, rather than all-thingsconsidered moral obligations. ${ }^{240}$ In other words, law may essentially make claims (to create binding moral obligations) that are often falsified. The problem of supremacy for the group-relative account is just like this: a given group's conception of U.S. law necessarily claims to have a special status in generating moral reasons for persons located within the U.S., but in fact parallel conceptions held by other groups will sometimes have just as much moral authority as the given conception.

In short, while the group-relative account implies that law is opaqueeach group's conception must claim a kind of supremacy which the grouprelative account denies to any such conception-and this is a weakness in the account, it is a weakness bound up with the contingency of law's actual moral authority, and is thus not avoided by designating a single, canonical recognitional group.

What about the worry that the group-relative account distorts our ordinary understanding of the concept of law? Why call group-relative dis-

\footnotetext{
236 Id. at 119.

237 Joseph Raz, Hart on Moral Rights and Legal Duties, 4 OXFORD J. LeGAL STUD. 123, 131

238 See supra note 204 and accompanying text.

239 See supra note 212 and accompanying text.

240 See, e.g., DWORKIN, supra note 80, at 202-06.
} (1984). 
course "legal"? Isn't law in this sense so far removed from what we ordinarily take to be "law" that the group-relative account is no longer an account of "law" at all? Here, the answer is that all jurisprudential analysis involves some reconstruction of our pretheorized constructs. ${ }^{24}$ For example, virtually no one prior to the publication of Hart's The Concept of Law consciously thought that law involved a rule of recognition, and the vast majority of those who use the term "law" still do not think that. My analysis preserves the central point of "law" as reconstructed by virtually all jurisprudential analysis starting with Hart, namely that "law" involves social facts. It also preserves a central feature of some of the most prominent post-Hartian reconstructions, namely that "law" figures, inter alia, in a normative discourse concerning moral authority. ${ }^{242}$

I will spend a bit more space on a final objection. Hart famously stipulates that a legal system exists only if it is sufficiently efficacious. Not only must the rule of recognition be accepted by officials, but in addition the primary rules validated by the rule must be more or less complied with by the citizenry and other subjects.

There are ... two minimum conditions necessary and sufficient for the existence of a legal system. On the one hand, those rules of behavior which are valid according to the system's ultimate criteria of validity must be generally obeyed and, on the other hand, its rule[] of recognition ... must be effectively accepted as common public standards of official behavior by its officials. ${ }^{243}$

Doesn't the efficacy condition vitiate group-relativity?

One wonders why an efficacy condition should be part of the picture. Why not simply say that a legal system exists, relative to some group, if the social fact undergirding law is actually instantiated in the group, whether or not the legal system thus created is effective or not? For example, if Coleman, Shapiro, and Kutz are correct that the social fact undergirding law is some kind of SCA, why not say that a $G_{\mathrm{i}}$-relative system of U.S. law exists if the members of $G_{i}$ implement an SCA (or some variant) the object of which is to develop and maintain a system of law grounded on the U.S. Constitution? Understand that an SCA of this sort can occur, even though the conception of constitutional law that the group members advance is not effective beyond the group. Understand, too, that the existence of an SCA

241 See Frank JaCkson, From Metaphysics to Ethics: A Defense of CONCEPTUAL ANalysis 45 (1998) (suggesting that conceptual analysis looks for "paraphrases" of, rather than synonyms for, folk concepts); Brian Bix, Conceptual Questions and Jurisprudence, 1 LEGAL THEORY 465, 472 (1995) (noting that conceptual analysis in legal theory rarely seeks to track ordinary usage, but more typically argues that a particular conceptualization "is justified on the basis that [it] better displays certain interesting or important aspects of the practice (aspects that may be hinted at by our linguistic practices)").

${ }^{242}$ I am thinking here of Dworkin's view that law creates genuine associative obligations, and Raz's view that law claims moral authority. See supra text accompanying notes 202-203.

243 HART, supra note 5, at 116; see LAGERSPETZ, supra note 56, at 167-84 (discussing efficacy condition); RAZ, supra note 74 , at 203-08 (same). 
whose conception of constitutional law is externally ineffective can play a role in both predictive/explanatory law-talk and normative law-talk. Consider the case of citizen constitutional reformers, united by the view that some range of activities widely engaged in by officials or other citizens are actually unconstitutional (slavery, race discrimination, gun regulation, land use regulation, etc.). The reformers' SCA with the object of effectuating that constitutional principle could help explain their activities, for example their lobbying and litigating activities (in other words, the nonreductionistic social scientist might make reference to the SCA), and someone believing the group to have epistemic authority could assert that the constitutional duties claimed by the group ought to be complied with, even though those putative duties are in fact generally ignored by non-group members.

Indeed, a group can instantiate an SCA aimed at developing a system of U.S. law consistent with some constitutional conception, without that SCA being fully effective internally. Imagine an administration jointly committed to the President's "anti-Federalist" view that the scope of the Commerce Clause is narrower than contemporaneous judicial doctrine holds, and to a denial of judicial supremacy. The Administration declines to enforce a variety of federal statutes that it believes exceed the Commerce Clause, but caves to political pressure and prosecutes high-profile violations of the drug laws and other politically popular laws that are unconstitutional under its anti-Federalist conception. So the putative constitutional duty (not to enforce laws exceeding a narrow construal of the Commerce power) is one that the Administration itself has not fully honored. Does this mean that members of the Administration don't jointly intend, with common knowledge and mutual responsiveness and support, to realize the President's views about the Commerce Clause-that their supposed SCA doesn't exist? Not necessarily, since the group's recognition of political constraints does not preclude the existence of those joint intentions or their explanatory role, e.g., in cases where no such constraints exist. Nor does the partial internal inefficacy of the administration's anti-Federalist constitutional conception preclude normative law-talk adducing it. This is clearest where the normative law-talk adduces epistemic authority. Political actors can be both particularly morally sensitive, as compared to other actors, and politically savvy. Lincoln and Roosevelt (plausibly) were.

In short, Hart's efficacy requirement supplements the basic existence conditions for law (the existence of a particular type of social fact that plays an explanatory or normative role), and it's unclear what would motivate this additional requirement. But let us assume that Hart is correct to require that a legal system be efficacious. Separate efficacy into two elements, subject efficacy and official efficacy. ${ }^{244}$ Assume that, where some group instantiates

244 See LAGERSPETZ, supra note 56, at 168 (generally discussing plausible efficacy conditions vis-àvis officials and citizens). Since nonofficial citizens need not, on Hart's account, do more than obey the 
the right sort of social fact for law, its constitutional conception amounts to an actual, existing system of U.S. constitutional law and, derivatively, U.S. law only if (in addition): (1) the legal duties flowing from that conception are generally complied with by nonofficial citizens and by other nonofficials, e.g., resident aliens, subject to those duties (subject efficacy); and (2) the legal duties imposed on officials by that conception are generally complied with (official efficacy). ${ }^{245}$ Both of these conditions, I suggest, can be simultaneously satisfied by multiple groups. So the conditions, if legitimate-and, again, I haven't conceded that they are-don't undermine the group-relative picture.

Consider, first, the subject-efficacy condition. Raz, discussing the "test of the general efficacy of legal systems," has pointed out that "[m]ore than one legal system may pass [such] test and be efficacious in a certain society."246 This is certainly true of the subject-efficacy test. A plurality of groups might have constitutional conceptions that generally converge in the set of statutes and regulations they recognize as duly enacted-in the content of the U.S. Code and Code of Federal Regulations-- but diverge as to the content of constitutional rights - that is, the circumstances under which courts should invalidate the statutes and regulations and the executive should decline to enforce them. ${ }^{247}$ If the statutes and regulations are in fact generally complied with until the courts invalidate them, or the executive announces that it won't enforce them, then the subject-efficacy condition has been satisfied by all the groups' constitutional conceptions, not just one.

As for the official-efficacy condition: a demanding version of this condition would, I suppose, call into question the group-relative picture of law (since it would very often occur that a pair of conceptions would recognize at least one pair of conflicting official duties, in which case the conceptions couldn't both be fully complied with by officials), but a demanding version of the condition is implausible. Why? Consider Supreme Court doctrine. Surely, if any system of U.S. legal rights and duties currently exists, it's the system asserted by current, nonoverruled, Supreme Court caselaw. But that system is far from fully, officially effective. Many official constitutional duties asserted by current doctrine are ignored. Congress continues to enact

rules of the system, it's hard to see why the citizen/subject distinction would matter for the Hartian, and so I have focused on subject efficacy rather than citizen efficacy.

245 See RAZ, supra note 74, at 204 ("The principle of efficacy is concerned only with obedience and disobedience to [duty-imposing] laws.").

246 Id. at 206.

247 More precisely, the conceptions might diverge as to the rights that they see as application rather than existence conditions-since divergence as to the existence conditions for law, whether those are taken from the original articles of the Constitution or from the Bill of Rights, would produce divergent views about the content of statutory and regulatory law. See generally Adler \& Dorf, supra note 98 (distinguishing between existence and application conditions). 
legislative vetoes. ${ }^{248}$ Prayer in public schools is widespread, in defiance of the Court's Establishment Clause decisions. ${ }^{249}$ Police routinely engage in searches that are illegal under the Court's Fourth Amendment jurisprudence. ${ }^{250}$ The South massively resisted Brown v. Board of Education. Lest it be objected that these and similar examples trade on Cooper v. Aaron: first, Cooper is a part of judicial doctrine that asserts a general nonjudicial duty to obey the rest of judicial doctrine, so the examples do show wide official disobedience of the duties that the Court believes to obtain; and, second, there are plenty of examples of noncompliance with judicial judgments. Consider official resistance to structural injunctions and consent decrees. ${ }^{251}$

Once the official-efficacy condition is relaxed to allow less than perfect compliance, multiple and partly conflicting constitutional conceptions can all satisfy this condition-particularly since part of the divergence will concern official powers, or other legal positions, not official duties. Imagine that Federalist Party legislators generally claim that Congress has broad power to regulate interstate commerce, while Anti-Federalists assert that the power is more limited and, further, that Congress is obligated to stay within the boundaries of this more limited power. Then, if the Anti-Federalists have enough votes to block the enactment of broad statutes, Congress complies both with the duties asserted by the Federalists and the more encompassing set of duties asserted by the Anti-Federalists. After all, the Federalists (and national power advocates generally) claim that Congress is constitutionally empowered to regulate broadly, not that it is constitutionally or otherwise legally obliged to do so.

\section{GROUP-RELATIVITY AND CONSTITUTIONAL LAW}

What are the implications of the group-relative view for U.S. constitutional theory, and, in particular, for recent debates about popular constitutionalism?

\section{A. The Structure of Constitutional Discourse}

Constitutional discourse, I have suggested, has two main variants: explanatory/predictive and normative. The group-relative view provides an account of both discourses. Holistic political scientists and sociologists may make assertions about U.S. constitutional law, not with the normative aim of recommending that officials, citizens, or subjects do certain things,

${ }^{248}$ See sources cited supra note 150.

249 See Kramer, We the Court, supra note 1, at 6 n.4.

${ }^{250}$ See Jon B. Gould \& Stephen D. Mastrofski, Suspect Searches: Assessing Police Behavior Under the U.S. Constitution, 3 CRIMINOLOGY \& PUB. POL'Y 315 (2004).

251 See, e.g., Spallone v. United States, 493 U.S. 265 (1990) (discussing the district court's appropriate use of the contempt power to force a city and city council members to comply with a consent decree in a civil rights suit). 
but rather with the non-normative aim of explaining what officials, citizens, or subjects have done in the past, or predicting what officials, citizens, or subjects will do in the future. The group-relative view analyzes an explanatory/predictive claim about the content of constitutional law as follows. Such a claim, as I see it, (1) implicitly or explicitly invokes some group of persons; (2) asserts that the group instantiates a certain kind of social fact (be it an SCA or variant, a Lewis-convention, Searlean collective intentionality, or a social norm); (3) asserts that the claimed proposition of constitutional law is derivable in the right sort of way from the social fact; and (4) presupposes that the underlying social fact and derived proposition are explanatorily useful.

For example, the political scientist might claim that "the Constitution prohibits the federal government from regulating purely intrastate commerce" in the course of explaining why a Republican agency head has declined to promulgate a proposed regulation. The group invoked could be the presidential Administration to which the official belongs, or the entire Republican party (citizens and legislators as well as executive officials), or the subset of Republican officials within the party, or the collectivity of all citizens, or some other group. I have been agnostic, in this Article, about the precise sort of social fact that undergirds law, and the precise way in which legal propositions are derivable from that type of foundational fact. Assume, for the sake of illustration, that the best account of explanatory/predictive legal discourse involves SCAs rather than Lewisconventions, norms, or other facts, and that the best account of derivation (for purposes of this discourse) is simple consensus. Then the explanatory/predictive claim that "the Constitution prohibits the federal government from regulating purely intrastate commerce" will be true if (1) the members of the invoked group (the presidential Administration, the entire Republican party, Republican party officials, the citizenry) satisfy the mutual commitment, support, and responsiveness conditions of an SCA, and (2) agree that "the Constitution prohibits the federal government from regulating purely intrastate commerce."

I will say no more here about the group-relative decomposition of explanatory/predictive legal discourse about the U.S. Constitution, since to do so would mean engaging debates about holistic versus individualistic methodologies for social science ${ }^{252}$ that are well beyond the scope of this Article, and since legal scholars who study the U.S. Constitution-my intended audience-are generally engaged in some kind of normative discourse: either legal discourse or straight moral discourse (for example, straight moral discourse about optimal constitutional structures). The group-relative account is an account of legal discourse, not straight moral discourse. Legal discourse essentially involves claims or presuppositions about the existence of

252 See supra text accompanying notes 192-195. 
social facts, while straight moral discourse does not. ${ }^{253}$ In particular, discourse about the morally optimal system of law does not, necessarily, assert the actual existence of certain social facts or group practices-merely that these facts or practices ought, morally, to obtain.

Let me focus, then, on normative, legal discourse about the U.S. Constitution: for example, "the Constitution prohibits the federal government from regulating purely intrastate commerce," asserted in the course of recommending that some person take or refrain from taking some action. Such a claim, fully unpacked, has a structure partly isomorphic to that of its explanatory/predictive twin. The claim does the following: It (1) implicitly or explicitly invokes some group of persons; (2) asserts that the group instantiates a certain kind of social fact (be it an SCA or variant, a Lewisconvention, Searlean collective intentionality, or a social norm); (3) asserts that the claimed proposition of constitutional law is derivable in the right sort of way from the social fact; and (4) asserts that the derived proposition has a certain kind of moral authority, be it epistemic, coordinative, consentbased, fair-play based, or associative.

What exactly does it mean for a participant in constitutional discourse to "invoke" a group? This question arises because my account of constitutional discourse is a partial reconstruction of actual law-talk, not a straightforward description of actual law-talk. As already noted, this reconstructive character is generally true of jurisprudential accounts of legal discourse, for example Hart's or Dworkin's. ${ }^{254}$ In arguing that claims about law invoke a rule of recognition, Hart certainly did not mean to assert that participants in legal systems generally talk about a rule of recognition per se, or have that notion present in their consciousness. Rather, Hart's argument (in effect) was that the most important things people actually say and consciously believe about law could only be true if law-talk was understood as invoking a rule of recognition. Similarly, my suggestion is that the most important feature of normative, legal discourse, namely its hybrid social and moral cast, is best accounted for by taking the speaker as invoking some social group. Actual speakers may not have any group consciously in mind-and so determining what group a lawyer, or legal scholar, or anyone else "means" to invoke will often be a matter of the speaker's dispositional intentions, perhaps idealized, rather than her occurent intentions, or maybe instead a matter of what group the speaker herself belongs to.

The notion of "invoking" a group raises some further puzzles. To begin, how is it possible to invoke groups that are defined in legal terms? After all, the extension of legal categories is itself a group-relative matter. The members of a devoutly religious group may believe that atheists can't be citizens; the members of an atheist sect may believe that devoutly religious people can't be citizens. So how is it possible to invoke "citizens," or

253 See supra text accompanying notes 33-36.

254 See supra text accompanying notes $241-242$. 
"officials," or "judges" as a group whose practices ground a system of constitutional law? The rough answer, which I gave earlier, is that if there is general consensus as to who "citizens" or "officials" or "judges" are, then these groups can be properly invoked. More precisely: if a legal category such as "U.S. officials" or "U.S. citizens" or "U.S. judges" has the same membership, regardless of which collection of natural persons instantiating the right sort of social fact for law and holding a conception of U.S. law is invoked, then that legal category does refer to a determinate group. If not, then it doesn't, and we might then say that an assertion that uses the legal category to invoke a recognitional group is meaningless, or instead perhaps that the group invoked is (1) the intersection or (2) the union of the legal groupings defined by the practices of the various collections of natural persons instantiating SCAs, Lewis-conventions, etc. and grounding conceptions of constitutional law. If the devoutly religious believe that everyone born in the U.S. except atheists are "citizens," the atheists believe that everyone born in the U.S. except the devoutly religious are "citizens," and all other groups recognize everyone born in the U.S. as citizens, then "citizens" either fails to identify a single group or, rather, might be understood as encompassing (1) all persons born in the U.S. except atheists or the devoutly religious, or (2) all persons born in the U.S.

What about arbitrary groups, such as blue-eyed persons over fifty-five? A group might be arbitrary in the sense that it is simply a collection of persons and not a group in any more robust way. In other words, it doesn't instantiate an SCA, Lewis-convention, Searlean collective intentionality, or social norm. Or, it might be sufficiently group-like but arbitrary in the sense that legal propositions about U.S. law aren't derivable from its practices. (Imagine a tight-knit collection of Martians.) Finally, a genuine group embodying a conception of U.S. law might be arbitrary in the sense that this conception pervasively lacks moral authority. Normative constitutional claims invoking groups that are "arbitrary" in any of these three senses will be false. So the problem of arbitrary groups is handily resolved.

The group-relative schema for normative, constitutional discourse that I have just sketched out is, in various ways, incomplete. It does not specify the sort of social fact that normative law-talk asserts, nor the way in which legal propositions derive from social facts. On the "derivation" issue, I particularly have in mind the debate between Dworkinians who claim that the link between social facts and legal propositions is necessarily "interpretive," and positivists who deny that. Nor, further, does the schema specify the way(s) in which law-talk claims authority (epistemically, coordinatively, or as a matter of consent, fair play, or associative obligation), nor does it make precise what sort of authority relation is being asserted (theoretical versus practical, exclusionary versus nonexclusionary). ${ }^{255}$ These are all problems too large to be tackled here. 
Even so, the group-relative schema has important implications for normative constitutional theory. First, and most obviously, it helps explain what statements about constitutional law mean. What are we scholars, or we lawyers, or we Americans really saying to each other when we assert (in normative mode) that the Constitution requires, prohibits, or permits something? The group-relative schema answers this very basic question, in a distinctive way. Consider, by way of contrast, a schema which unpacks constitutional assertions as invoking some single, canonical group. On this schema, a constitutional assertion means that the canonical group-be it judges, officials, or citizens-instantiates a certain sort of social fact, that the asserted proposition derives from that fact, and that the proposition has some kind of moral authority. The group-relative schema, instead, allows statements about constitutional law to invoke different groups. This changes, in a deep way, the semantics of the discourse. We don't (fully) know what a statement such as "the Constitution prohibits the federal regulation of purely intrastate commerce" means until we know whether the speaker is pointing to official practices, church practices, party practices, judicial practices, presidential practices, or the practices of some other collectivity, as the practices from which the impermissibility of intrastate regulation derives.

Relatedly, and equally deeply, the group-relative account clarifies the truth conditions for propositions of constitutional law. Constitutional propositions are not true or false simpliciter; rather, they are made true or false by the practices of the invoked group, and thus can be true relative to one group but false relative to another. This is evidently a large change from the canonical view. Consider the traditional, positivist, Hartian variant of this view that identifies true legal propositions as those derivable from an ultimate secondary rule, the rule of recognition, understood as a Lewis-convention among officials. "The Constitution prohibits the federal regulation of purely intrastate commerce" is true, for this sort of canonical theorist, only if all U.S. officials coordinate on a set of conventional rules from which one might deduce that purely intrastate commerce may not be federally regulated. By contrast, on my group-relative account, "the Constitution prohibits the federal regulation of purely intrastate commerce" could be both true (perhaps polymorphously) and false (perhaps polymorphously). If the members of the current presidential Administration, Republicans in the Congress, the Justices of the Supreme Court, and the members of a citizens' advocacy group Lewis-conventionally accept rules that say or imply that Congress lacks the power to regulate purely intrastate commerce, but Democrats in the Congress, federal judges generally, or citizens generally do not accept such rules, then it may be true relative to one or more of the 
first four groups, ${ }^{256}$ but must be false relative to the next three, that Congress legally lacks this power.

If constitutional truth is group-relative, then Dworkin's famous claim that there are right answers to every constitutional question must be qualified. ${ }^{257}$ Dworkin may be correct that, relative to one or another group, every constitutional proposition is either true (specifically, in the Dworkinian view, in virtue of an "interpretation" of the group's practices), or false. It may well be that no constitutional proposition has a group-relative indeterminate truth value. But constitutional propositions certainly do have indeterminate truth values prior to the specification of some particular groupjust as the sentence "I am six feet tall" taken as a class of statements, not as a particular statement uttered by a particular person, has an indeterminate truth-value. ${ }^{258}$ "I am six feet tall" will be true when uttered by a sufficiently tall speaker, false when uttered by a short one, just as "the Constitution prohibits the federal regulation of purely intrastate commerce" can be both true relative to a states-rights group and false relative to a nationalist one.

Here's another way to make the point. On the group-relative schema, any constitutional statement should be understood as a statement involving an indexical reference to a particular group. "The Constitution prohibits the federal regulation of purely intrastate commerce" means roughly, "That group has a constitutional conception which prohibits the federal regulation of purely intrastate commerce, and which on that point is in fact morally authoritative." The truth of this statement depends on which particular group "that group" refers to-just as the statement "that building is a skyscraper" is true when uttered in a context where "that building" refers to a skyscraper, false when uttered in a context where its referent is not a skyscraper.

One final, general implication of the group-relative view: It provides a clear and distinctive way to understand the role of social practice in constitutional law, both within a system of constitutional law and at the foundations of any such system.

Social practice might be present (what people do and think now) or it might be past (what people did or thought at some particular past moment, or over time). Social practice, either past or present, can certainly play a role within the fabric of constitutional law. Group $G_{i}$ 's practices can give rise to a system of constitutional law that incorporates facts about the practices of groups $K_{1}, K_{2} \ldots K_{\mathrm{n}}$. There is nothing in the group-relative picture to insist that the $K_{\mathrm{j}}$ be contemporary groups. For example, $G_{\mathrm{i}}$ 's practices might give great weight to the text of the Constitution, and look to the

256 I say "may be" because the truth of normative legal claims entails not merely the existence of the appropriate social fact, but also that the legal propositions asserted have some kind of moral authority.

257 See BIX, supra note 79, at 87-89.

258 See, e.g., DAVID J. ChAlMERS, THE CONSCIOUS MIND 60 (1996) (discussing "indexical terms[,] such as 'I,' whose reference clearly depends on who is using the term"). 
original meaning of the text's provisions (a kind of social fact concerning the shared, linguistic understandings of framing or ratifying groups or society at large at the particular past moments when the text was promulgated or amended), or to the country's "traditions" concerning the principles set forth in the text (a kind of intertemporal social fact). ${ }^{259}$

But does social practice have any deeper role in constitutionalism than this contingent, derivative role? And, if social practice does have a deeper role, is that present or past practice? Hart's answer to the first question, of course, is that social practice does have a deeper role. His answer to the second is that the social practice foundational to law is present, not past practice. U.S. law at $T^{*}$, for Hart, is determined by the Lewis-conventions at $T^{*}$ among U.S. officials. ${ }^{260}$ Positivists such as Shapiro, Coleman, Kutz, and Raz generally seem to share Hart's presentism; ${ }^{261}$ Dworkin is less clear on the matter, as discussed earlier. ${ }^{262}$

The group-relative schema I have presented concurs with Hart that social practice does have a foundational role in determining law. There are multiple fine-grained systems of U.S. constitutional law, each one resting upon facts about some group $G_{i}$. But what about the question of presentism? Do the foundational groups have to be present groups? On this issue, one of much relevance to "popular constitutionalism," the group-relative view is (at least formally) agnostic. If the sort of social fact foundational to law can be instantiated by groups existing at some particular past time, or intertemporal groups, then (perhaps) systems of constitutional law can be defined relative to past and not just present groups. That is: the constitutional discussant might, perhaps, correctly assert, at $T^{*}$, that some constitutional proposition is true (at $T^{*}$ ), invoking Lewis-conventions, SCAs or variants, Searlean collective intentions, or social norms, that are in force among some group not at $T^{*}$, but at an earlier time, or intertemporally.

Or perhaps not. An obvious difficulty with the invocation of intertemporal social facts is that the standard definitions of social facts make them

${ }^{259}$ On the use of "traditions" in this sense in interpreting the Constitution, see, for example, Washington v. Glucksberg, 521 U.S. 702, 710, 710-18 (1997) (stating that "[w]e begin, as we do in all due process cases, by examining our Nation's history, legal traditions, and practices," and relying on the Anglo-American tradition of disapproving suicide and assisted suicide in determining that substantive due process does not protect assisted suicide).

${ }^{260}$ See HART, supra note 5, at 120-22 (suggesting that, as a new rule of recognition emerges in a territory, a new legal system emerges at the same time).

${ }^{261}$ See, e.g., RAZ, supra note 74, at $192 \&$ n.l. Alexander and Schauer provide a nice statement of the presentism that seems characteristic of Hart and post-Hartian positivism:

It could, of course, be the case that a society adopted as its . . . rule of recognition[] the principle that all questions about the content of its constitutional rules ... would be decided by [reference to the past]. But even such a principle of historical reference would owe its political validity and its status as law to current acceptance rather than historical provenance. The present, and not the past, decides whether the past is relevant.

Alexander \& Schauer, supra note 21, at 1370 (internal citations omitted).

262 See supra text accompanying notes 81-84. 
momentary or at most generational, ${ }^{263}$ rather than more robustly enduring. Consider, as an illustration, Lewis-conventions. If Sam died before Sheila was born, then Sam and Sheila can't (it seems) be part of the same Lewisconvention. Lewis-conventions involve a perfectly symmetrical interaction of behavior and expectations about others' behavior: I conform to $R_{1}$ because I expect you and everyone else in the group to conform to $R_{1}$, and I would conform to $R_{2}$ if I expected you and everyone else in the group to conform to $R_{2}$. Reciprocally, you conform to $R_{1}$ because you expect me and everyone else in the group to conform to $R_{1}$, and you would conform to $R_{2}$ if you expected me and everyone else in the group to conform to $R_{2}{ }^{264} \mathrm{We}$ might try to transpose this to the intertemporal case by adding past and future tenses-Sheila conforms to $R_{1}$ because she expects that Sam conformed to $R_{1}$, and she would conform to $R_{2}$ if she expected that Sam conformed to $R_{2}$; Sam conformed to $R_{1}$ because he expected that Sheila would later conform to $R_{1}$, and would have conformed to $R_{2}$ if he had expected that Sheila would later conform to $R_{2}$-but even so the symmetry would be broken, since Sam's prior behavior could be causing Sheila's subsequent expectation, while Sheila's subsequent behavior could not (of course) be causing Sam's prior expectation.

Invoking past momentary Lewis-conventions to establish present truths about law is less obviously problematic: If officials in 1825, say, coordinated on a rule of recognition, then why couldn't that rule be applied to deduce constitutional truths in 1840 , or 1920 , or at present, and not merely in 1825? The issue here, I suppose, has to do with law's authority. Past Lewis-conventions don't presently have coordinative authority-although they might presently have epistemic authority. The temporal questions here are deep and bear much more analysis than can be given here. In any event, the group-relative account affords the framework within which to consider them.

\section{B. Popular Constitutionalism, Shallow and Deep}

Turn, now, to consider the implications of the group-relative account for recent debates about popular constitutionalism. The account has very large implications, I suggest, for it points to a crucial distinction between the recognitional role of the populace and the role of popular (rather than judicial) constitutional decisionmaking within a given system of constitutional law. In other words, popular constitutionalism and its adversary, judicial supremacy, might be shallow or deep.

${ }^{263}$ Cf. Frank I. Michelman, Constitutional Authorship by the People, 74 NOTRE DAME L. REV. 1605, 1623 (1999) (discussing Ackerman's view that "the generation [i]s the basic object of [constitutional] fidelity"); Jed RuBENFELd, FREEDOM AND TIME: A THEORY OF CONSTITUTIONAL SELFGOVERNMENT 56-67 (2001) (criticizing a generational account of "We the People").

${ }^{264}$ See LEWIS, supra note 40 , at 76. 
Shallow popular constitutionalism and shallow judicial supremacy are claims about the content of constitutional law, specifically about the structure of constitutional decisionmaking. Relative to one or another invoked group $G_{\mathrm{i}}$, shallow popular constitutionalists and shallow judicial supremacists have different views about the role of the Supreme Court in constitutional decisionmaking. These are views about constitutional law, not invocations of different foundational groups, and do not (to be true) need to invoke one particular kind of $G_{\mathrm{i}}$. By contrast, deep popular constitutionalism and deep judicial supremacy involve claims about $G_{i}$ : either that constitutional law must rest upon the practices of one particular kind of group-the citizenry in the case of deep populism, the judiciary in the case of deep judicial supremacy-or (less robustly) that constitutional law can rest upon the practices of that kind of group.

The shallow judicial supremacist, specifically, endorses Cooper $v$. Aaron: she claims that Supreme Court holdings bind the world ${ }^{265}$ and perhaps also that the Supreme Court should be fairly nondeferential in reaching these holdings. ${ }^{266}$ The shallow popular constitutionalist rejects Cooper, more or less dramatically. At a minimum, she is a "departmentalist," who thinks that certain institutions-paradigmatically Congress, perhaps also the President, state legislatures, federal agencies, and other actors-are not bound by Supreme Court holdings. ${ }^{267}$ The shallow popular constitutionalist may also reject Supreme Court constitutional decisionmaking more decisively, urging broad judicial deference or even wholesale judicial nonenforcement of some, maybe most, of the Constitution. ${ }^{268}$ Or, she may couple her rejection of Cooper with the claim that ordinary citizens-not merely legislators and other nonjudicial officials-have some substantial role in deciding constitutional questions. ${ }^{269}$ For example, the claim that judges and legislators should defer to popular constitutional views expressed in pivotal elections would amount to a kind of shallow popular constitutionalism. So would the claim that citizens, in their role as jurors, should take account of constitutional issues without feeling bound by Supreme Court holdings.

Deep popular constitutionalism, in its most robust form, claims that the citizenry is the canonical group whose practices determine constitutional law. The most robust variant of deep judicial supremacy says the same about the Supreme Court. Both these views are wrong: the group-relative view entails that they are wrong, of course, for it says that there is no single, canonical, recognitional group. Deep judicial supremacy, less robustly, says that the Supreme Court (or the federal judiciary more generally) is one

265 See Alexander \& Schauer, supra note 21 (defending Cooper v. Aaron); id. at 1362 n.12 (citing other defenders).

266 See, e.g., DWORKIN, supra note 92, at 131-49.

267 See sources cited supra notes $21,23$.

268 See sources cited supra note 17.

269 See sources cited supra note 13. 
of the groups, among others, that instantiates Lewis-conventions, SCAs, Searlean collective intentionality, or social norms, and that can be invoked to make true assertions about constitutional law. Deep popular constitutionalism, less robustly, says the same about the citizenry.

The shallow and deep views are entirely different sorts of views; they can be mixed and matched. Shallow judicial supremacy doesn't entail deep judicial supremacy, and indeed is quite consistent with deep popular constitutionalism. Similarly, shallow popular constitutionalism doesn't entail deep popular constitutionalism, and is quite consistent with deep judicial supremacy. Larry Alexander and Fred Schauer's well-known article on Cooper v. Aaron nicely illustrates the detachability of shallow and deep. The Alexander/Schauer article is the most vigorous and sustained defense in the scholarly literature of judicial supremacy, arguing that stability and coordination are crucial constitutional and moral values which demand a single authoritative decisionmaker, the Supreme Court. ${ }^{270}$ This kind of argument need not invoke Supreme Court practices themselves as the foundation for constitutional law. The argument, instead, might be (1) that the rule of recognition, understood as an SCA or Lewis-convention or "constitutive" rule or social norm among society at large, already recognizes Supreme Court holdings as legally decisive, and that these holdings already have coordinative moral authority; or it might be (2) that a rule of recognition, understood as an SCA or Lewis-convention or "constitutive" rule or social norm among society at large, which recognized Supreme Court holdings as legally decisive would be morally optimal in virtue of the coordinative function that would thereby accrue to these holdings. In short, the Alexander/Schauer defense of Cooper is a defense of shallow judicial supremacy readily married to a deeper popular constitutionalism - and various statements in the article suggest that Alexander and Schauer are, in fact, deep popular constitutionalists or at least are not deep judicial supremacists. They talk about "a society" - not merely judges- "adopt[ing] [one or another] grundnorm, or ultimate rule of recognition"271 and in an interesting footnote write: "Who are the addressees of our prescriptions [to accept Cooper v. Aaron]? Perhaps they are nonjudicial officials, because we are urging those officials to treat judicial opinions as authoritative. But at a deeper level, we are speaking to society, as institutional designer."272 The suggestion here is that "society" as a whole-as distinct from both judges and nonjudicial officials-is the recognitional community for constitutional law.

Ken Himma's work on the rule of recognition and constitutional law is an even more explicit illustration of the detachability of shallow and deep judicial supremacy. Himma, in Hartian style, is a deep official-not judi-

\footnotetext{
270 See Alexander \& Schauer, supra note 21, at 1369-81.

271 Id. at 1370 (internal citations omitted).

${ }^{272}$ Id. at 1379 n. 85 .
} 
cial-supremacist. He sees the rule of recognition as a practice among officialdom as a whole:

It is important to realize that judicial officials are not the only participants whose behavior and attitudes figure into determining the existence and content of the rule of recognition .... [Rather], the existence and content of the rule of recognition depend on the joint practices of both judges and other officials. ${ }^{273}$

But Himma joins his deep official supremacy with shallow judicial supremacy: what the rule of recognition requires, as he sees it, is for nonjudicial actors to defer to Supreme Court interpretations of the Constitution. ${ }^{274}$

The Alexander/Schauer and Himma articles exemplify the conjunction of shallow judicial supremacy with a deep antisupremacy: deep popular constitutionalism in the case of Alexander and Schauer, deep official supremacy in the case of Himma. It is harder to find good examples of the reciprocal view, which conjoins deep judicial supremacy with a shallower embrace of popular constitutionalism, that is, a rejection of Cooper $v$. Aaron and an endorsement of legal doctrines that give nonjudicial officials and perhaps the citizenry a role in constitutional decisionmaking. Positivists steeped in Hart will be deep official, not judicial, supremacists. U.S. constitutional lawyers, steeped in the rhetoric of "We the People," will tend to be intuitive deep popular constitutionalists. Still, the position just sketched is quite coherent. Imagine a theorist who (1) takes law's authority to be primarily epistemic; (2) believes that judges, in virtue of their insulation and training, have special moral expertise and thus are best placed to be epistemic authorities, especially in the context of deciding concrete cases; and (3) believes that democracy is intrinsically morally valuable. This conjunction of views could well lead to deep judicial supremacy but a rejection of Cooper.

Most of the recent scholarly literature on judicial supremacy and popular constitutionalism has consisted in a debate between the proponents of shallow judicial supremacy (such as Schauer and Alexander) and the proponents of shallow popular constitutionalism (such as Kramer, Tushnet, Whittington, and many others). ${ }^{275}$ The deeper problem of the recognitional community has not been explicitly engaged. This shallow debate about constitutional decisionmaking structures is a genuine legal debate, like familiar legal debates about constitutional rights, the separation of powers, or constitutional federalism. More precisely, insofar as one scholar explicitly or implicitly invokes a particular recognitional group $G^{*}$ in arguing for a particular set of constitutional decisionmaking doctrines, and another

273 Himma, supra note 48, at 154.

274 See id. at 186. For a more recent statement of Himma's views, see Kenneth Einar Himma, Final Authority to Bind with Moral Mistakes: On the Explanatory Potential of Inclusive Legal Positivism, 24 LAW \& PHIL. 1 (2005).

${ }^{275}$ See sources cited supra notes 21, 23, 265. 
scholar invokes the same group $G^{*}$ to argue for a different set of doctrines, this will be a genuine legal debate. The scholars can bring to bear the normal sources of constitutional argument-text, structure, constitutional history, original intentions, moral argument, precedent - to support Cooper or its rejection. To be sure, the relevance and weight of any particular source is contestable: that will depend, ultimately, on the sort of social practice that undergirds law, on the way in which constitutional propositions derive from underlying social practice, and on the particular group $G^{*}$ that is being invoked. Whether moral considerations as opposed to constitutional history and original intentions, say, have the greatest legal relevance in determining the legal correctness of Cooper depends-ultimately - on the social facts on the ground and on the general link (intrinsically moralized?) between social facts and law. But this is of course true of constitutional argument generally.

While the debate between shallow judicial supremacy and shallow popular constitutionalism can be a genuine legal debate, the debate between deep judicial supremacy and deep popular constitutionalism cannot be. Imagine that one scholar defends a particular constitutional doctrine (about rights, separation of powers, federalism) by appealing to the Supreme Court as the ultimate recognitional group, and another rejects the doctrine by appealing to the citizenry as the ultimate recognitional group. Then the scholars are talking past each other, legally. In general, genuine debate about the demands of social norms or practice requires that the interlocutors be appealing to the same group. If I'm criticizing a particular dressing behavior as socially inappropriate, invoking the norms of investment bankers, and you're defending the behavior as socially appropriate, invoking the norms of fashionistas, then there's no genuine argument here about the content of social norms. For interlocutors to be engaged in genuine argument, it must be that only one of them can be correct-but in the fashion fuss just described, it might well be true that the fussed-about behavior is both inappropriate relative to investment banker practices and appropriate relative to fashionista practices.

Constitutional debate posits a recognitional group. That invocation or positing, together with facts about the group and a general methodology for deriving legal propositions from recognitional practices, will validate and weight different sources of constitutional argument--which can then be used to determine the correctness of different constitutional doctrines. These are genuine sources of constitutional argument in virtue of the initial posit; they don't validate the posit itself. To try to adjudicate between deep popular constitutionalism and deep judicial supremacy by appealing to constitutional text, original intentions, structure, moral arguments, and prece- 
dent in the normal style of constitutional analysis would be a category mistake. ${ }^{276}$

How, then, to resolve the "debate" between deep popular constitutionalism and deep judicial supremacy? One might try to bring into play considerations of moral authority. It is conceptually misguided to characterize the invocation of the citizenry rather than the judiciary as a recognitional group, or vice versa, as legally correct; but perhaps it might be said that the views are morally correct or incorrect, in the following sense. I invoke Supreme Court practice, deriving a range of legal propositions from it and asserting moral authority for those propositions. You invoke citizen practice, deriving different propositions and asserting moral authority for those. If my claim of moral authority pervasively fails, while yours pervasively succeeds, then we might say that deep judicial supremacy is morally falsified, while deep popular constitutionalism is morally validated. But there are other possibilities, too. Both the deep judicial supremacist's claim that judicial practice pervasively lends moral authority to the legal propositions derived from that practice, and the deep popular constitutionalist's claim that popular practice pervasively lends moral authority to the legal propositions derived from that practice, could perhaps be true: for example, if the Supreme Court has pervasive epistemic authority and popular practice creates pervasive associative obligations. More plausibly, it could occur that deep supremacist and deep populist moral-authority claims are both partially borne out: each system of constitutional law has piecemeal moral authority, with respect to some but not all legal positions or some but not all persons. ${ }^{277}$

Here's a different, moralized construal of the "debate" between deep judicial supremacy and deep popular constitutionalism. Which invocation practice is morally best? Is it morally best for judges, officials and citizens

${ }^{276}$ It might be objected that a group's practices may be self-validating. Relative to a given recognitional community $G^{*}$, the identification of that community as the recognitional group may be legally required. Indeed, it might be argued that recognitional groups are necessarily self-validating, given that law necessarily claims supremacy. See supra text accompanying notes 235-240. Even if this is true, it strikes me that a group's practices would not self-validate via the standard sources of constitutional argument- the Constitution's text, the Framers' intentions, the text's structure, moral arguments, and precedent. The standard sources function to generate deontic positions for actors, typically governmental officials. They do not function to generate obligations for those engaged in normative discourse to make certain kinds of normative assertions-to invoke one rather than another group.

And even if this last point is incorrect-even if each group does self-validate via the standard sources of constitutional argument--those sources will not adjudicate between different recognitional groups. In particular, the sources will not adjudicate between deep popular constitutionalism and deep judicial supremacy. The deep popular constitutionalist invokes the citizenry as a recognitional group; the deep judicial supremacist invokes the judiciary as a recognitional group. Assume that groups selfvalidate. Relative to the citizenry, the invocation of the citizenry is legally valid; but relative to the judiciary, the invocation of the judiciary is legally valid. So neither the group practices, nor the sources of constitutional argument that they validate in different ways, will settle this dispute.

277 See supra text accompanying notes 212,222 (discussing possibility of piecemeal authority and of multiple types of authority). 
to think of judges as the recognitional community and to guide their behavior using legal propositions thus derived, or instead to think of the citizenry as the recognitional community and to follow a different set of legal propositions? Leaving aside the possibility of an exact tie, one of these invocational practices will be morally better than the other. But both might be morally worse than a hybrid system, where different actors identify with different recognitional groups. Much scholarship about U.S. constitutional law appeals to the value of competition: for example, competition between the branches, ${ }^{278}$ between the states, between the states and the federal government, ${ }^{279}$ and between political parties. ${ }^{280}$ Competition at the level of recognitional appeals could also be valuable-for example, a deep departmental competition between Supreme Court Justices who take Supreme Court practice as foundational, and legislators who take legislative (or citizen) practice as foundational.

Finally, one might ask whether the groups invoked by the deep judicial supremacist and deep popular constitutionalist are genuine groups: whether they instantiate the sort of social fact that grounds law. The answer to this question depends of course on what kind of fact that is. It also depends on whether the groups invoked are past or present. One variant of deep popular constitutionalism takes talk of an enduring "We the People" seriously and invokes an intertemporal citizen group. A different variant is presentist and invokes contemporary citizen practices. Jed Rubenfeld would certainly be comfortable with the intertemporal version of deep popular constitutionalism; ${ }^{281}$ I'm not sure that Mark Tushnet or Larry Kramer would be, ${ }^{282}$ and indeed (as suggested earlier) there are serious problems in understanding how intertemporal groups can realize SCAs or variants, Searlean collective intentions, Lewis-conventions, or social norms. ${ }^{283}$

${ }^{278}$ Cf. M. Elizabeth Magill, The Real Separation in Separation of Powers Law, 86 VA. L. REV. $1127,1129-30$ (2000) (critically examining the consensus view, among judges and legal scholars, that "separation of powers is a way to prevent a single institution of government from accumulating excessive political power; the way to achieve that objective is to disperse the three governmental powerslegislative, executive, and judicial-among different institutions and to equip each department with select powers to protect itself and to police the other departments").

279 See, e.g., Matthew D. Adler \& Seth F. Kreimer, The New Etiquette of Federalism: New York, Printz, and Yeskey, 1998 SUP. CT. REV. 71, 77-82 (discussing standard rationales for constitutional federalism, including Tiebout's and Brandeis's rationales, which involve interstate competition, and the tyranny-prevention rationale, which involves competition between the states and the federal government).

${ }^{280}$ See, e.g., Larry D. Kramer, Putting the Politics Back into the Political Safeguards of Federalism, 100 COLUM. L. REV. 215 (2000).

281 See RUBENFELD, supra note 263, at 145 (viewing "We the People" as "an agent existing over time, across generations").

${ }^{282}$ See sources cited supra note 1.

283 See also Michelman, supra note 263, at 1611-29 (accepting that present social practice grounds the present U.S. legal system, and viewing a past "We the People" as an entity whose construction and legal relevance rests upon present practice). 
These problems are avoided by the presentist version of deep popular constitutionalism, which (qua presentist) is on a par with the deep judicial supremacism that invokes present Supreme Court practice as foundational. If the kind of social fact undergirding law is a full-blown SCA, then it might emerge that neither Supreme Court practice nor citizen practice meets the standard. Do the various members of the Supreme Court, despite strong ideological disagreements, all (with common knowledge) actually intend, not merely to work together to craft validity criteria, but to mesh their divergent views and to support each other's work? Perhaps not. Reciprocally, if the question is whether the members converge on some constitutional propositions and there is some conventional element to this convergence, both the Supreme Court and the citizenry might be genuine groups.

In short, surprising as it may sound, deep judicial supremacy and deep popular constitutionalism are not genuinely opposing positions. Legal argument can invoke either the citizenry or the judiciary as a recognitional group, and cannot settle which of the two should be invoked. One, both, or neither group might be a true group, in the sense of embodying an SCA, Lewis-convention, Searlean collective intention, or social norm. Legal propositions validated with reference to both groups' practices might have moral authority, in part or even generally. And a deeply competitive social system where some actors make legal arguments by invoking judicial practice, while others invoke popular practice, could (at least in principle) morally dominate a more homogenous regime.

\section{CONCLUSION}

The law within each legal system is a function of the practices of some social group. In short, law is a kind of socially grounded norm. This is a point of consensus for modern jurisprudents in the Anglo-American tradition: not just Hart and his followers in the positivist school, most prominently Joseph Raz and Jules Coleman, but also the antipositivist Dworkin, who argues that law necessarily synthesizes moral considerations with social facts.

But which group's practices ground each legal system? In particular, which group's practices undergird U.S. law? Positivists since Hart have universally pointed to either officials or judges as the "recognitional community" (my term): the group whose rules, conventions, cooperative activities, or practices in some other sense are the social facts from which the law of a given legal system derives.

This Article has grappled with the tension between the positivist's official- or judge-centered account of the recognitional community and the "popular constitutionalism" now so widely defended by constitutional scholars such as Larry Kramer, Mark Tushnet, Jeremy Waldron, and many others. Surely many of these scholars would be troubled by the official- or 
judge-centric character of modern positivism--by its implication that the legal role of citizens in constitutional decisionmaking is ultimately determined by official or judicial practice. Surely they would be tempted to claim that U.S. citizens, not judges or officials, are the recognitional community for U.S. law. I have termed this position "deep popular constitutionalism." Indeed, it turns out-I have argued-that Dworkin's account of law, in its ambition to generate associative duties for the citizenry as a whole, suggests deep popular constitutionalism. Here there is a disagreement, hitherto unnoticed, between Dworkin and the positivists.

My solution to this disagreement-to the debate between deep popular constitutionalists and deep official or judicial supremacists-is to dissolve it by providing a group-relative account of law. In arguing for that account, I have shown that throughout U.S. history a plurality of groups, both official and citizen groups, have actively sought to advance conceptions of U.S. constitutional law. Further, I have argued that "law," taken either as an explanatory construct or as a normative construct, is best specified along group-relative lines. Finally, I have explored the implications of the grouprelative account for U.S. constitutional theory.

Whatever the merits of the group-relative account of law, I hope this Article has accomplished one thing: to put the problem of the recognitional community on the agenda of constitutional theory. Analytic jurisprudence is not easy reading, and for those steeped in our constitutional history some of the literature may seem naïve in underplaying how contested fundamental questions of U.S. law have been. ${ }^{284}$ Still, this is a literature that constitutional scholars ignore at their peril. Works such as Hart's The Concept of Law, ${ }^{285}$ Dworkin's Law's Empire, ${ }^{286}$ and Raz's The Concept of a Legal Sys$t^{t e m^{287}}$ try to determine, with the greatest intensity and rigor, just what law is -in particular, just how the law governing some society connects to other facts about that society, or about some subset within it. At some point, surely, that connection is one that the intellectually serious constitutionalist will need to try to understand.

${ }^{284}$ Consider, for example, Ken Himma's assertion that "[nonjudicial] officials have a consistent history of treating the Court's decisions as law, regardless of which direction they go." Himma, supra note 48 , at 175 . That assertion overlooks the long history of debate about judicial supremacy. See supra text accompanying notes 145-152. Or consider Scott Shapiro's view that officials as a whole within a legal system are engaged in the proto-SCA of creating and maintaining a unified system of rules-a view that, I have suggested, is difficult to square with the U.S. experience. See supra Part II.A.

285 See HART, supra note 5.

${ }^{286}$ See DwORKIN, supra note 80.

287 See RAZ, supra note 74. 
NORTHWESTER N UNIVERSITY LA W REVIEW 